US Army Corps

of Engineers ${ }_{\circledast}$

Engineer Research and

Development Center

Army Net Zero Program

\title{
Composting Assessment for Organic Solid Waste at Fort Polk, Louisiana
}

Victor F. Medina, Michelle Wynter, Stephen Cosper,

April 2014

Giselle Rodriguez, Dick Gebhart, Sam Hunter, and Patricia Kemme 
The US Army Engineer Research and Development Center (ERDC) solves the nation's toughest engineering and environmental challenges. ERDC develops innovative solutions in civil and military engineering, geospatial sciences, water resources, and environmental sciences for the Army, the Department of Defense, civilian agencies, and our nation's public good. Find out more at www.erdc.usace.army.mil.

To search for other technical reports published by ERDC, visit the ERDC online library at http://acwc.sdp.sirsi.net/client/default. 


\title{
Composting Assessment for Organic Solid Waste at Fort Polk, Louisiana
}

\author{
Victor F. Medina and Michelle Wynter \\ Environmental Laboratory \\ US Army Engineer Research and Development Center \\ 3909 Halls Ferry Road \\ Vicksburg, MS 39180-6199 \\ Stephen Cosper, Giselle Rodriguez, Dick Gebhart, Sam Hunter, \\ and Patricia Kemme \\ Construction Engineering Research Laboratory \\ US Army Engineer Research and Development Center \\ 2909 Newmark Drive \\ Champaign, IL 61826-9005
}

Final report

Approved for public release; distribution is unlimited.

Prepared for US Army Corps of Engineers

Washington, DC 20314-1000 


\section{Abstract}

A study was conducted to evaluate composting as a means of increasing waste diversion at Ft. Polk, LA. Wastes were evaluated from a range of activities, and the authors found that a number of materials currently landfilled are suitable for composting, including: vegetation, food wastes, pulverized paper (which is not suitable for recycling), consumer-contaminated paper (not suitable for recycling), damaged wood pallets, and sludge from the wastewater treatment plants. Waste records from Ft. Polk suggest a composting operation producing at least 2200 tons per year (from a food waste/vegetation strategy) is feasible. This would represent considerable solid waste diversion, consistent with meeting Net Zero Waste Goals. Between the Integrated Training Area Management (ITAM), the Directorate for Family, Morale, Welfare, and Recreation (DFMWR) (golf course, athletic and drill fields), and smaller groups, there are enough users to consume all the compost that could be generated from an on-site operation. A suitable area for on-site composting is available. There are also other alternatives to on-site composting, including current management, which is outlined in this report; other means of waste diversion (including direct soil application of certain waste materials and anaerobic digestion of food wastes); and the possibility of developing partnerships with composting facilities offsite. Although this project is focused on Ft. Polk, the assessment could be - in a broad sense - applicable to other Army installations. In addition, the issues found at the Joint Training and Readiness Center (JTRC) might have applicability to contingency environments and deployed operations.

DISCLAIMER: The contents of this report are not to be used for advertising, publication, or promotional purposes. Citation of trade names does not constitute an official endorsement or approval of the use of such commercial products. All product names and trademarks cited are the property of their respective owners. The findings of this report are not to be construed as an official Department of the Army position unless so designated by other authorized documents. 


\section{Contents}

Abstract...................................................................................................................................... if

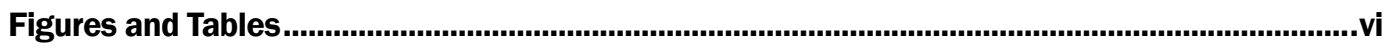

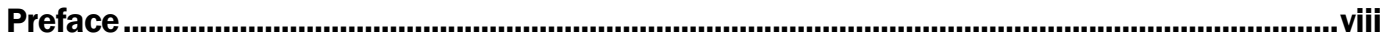

Unit Conversion Factors ....................................................................................................

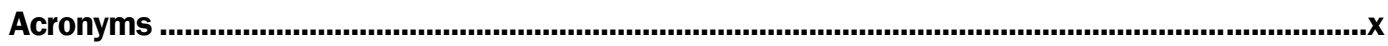

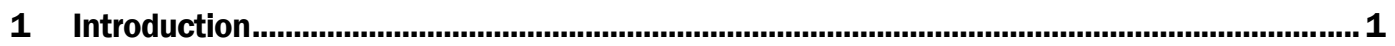

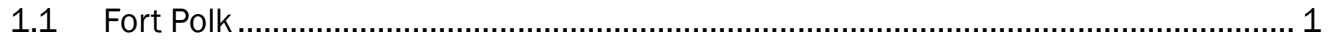

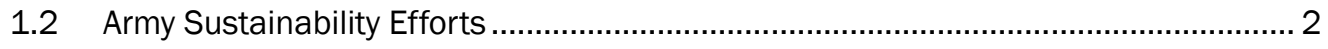

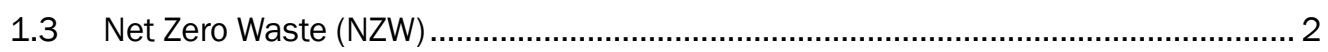

2 Composting - State of the Art ....................................................................................... 4

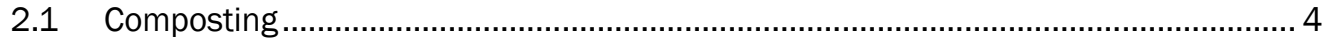

2.2 Operating Parameters .................................................................................... 4

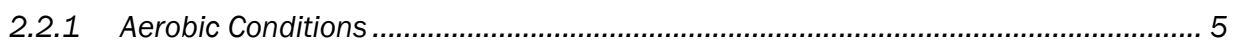

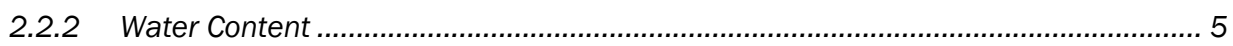

2.2.3 Thermophilic Conditions ................................................................................. 5

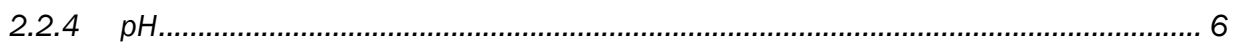

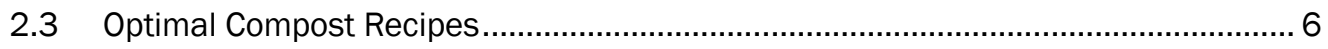

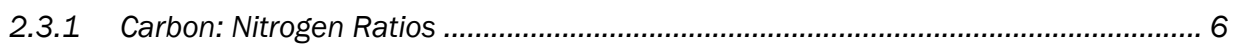

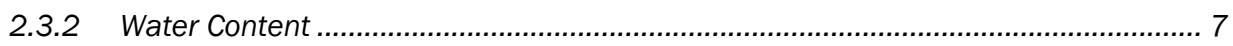

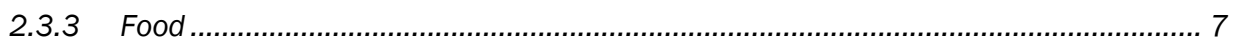

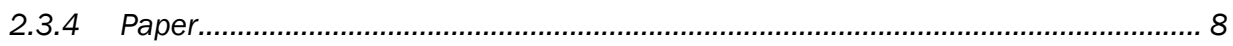

2.3.5 Biodegradable/Compostable Replacement Materials for Plastics, Rubber,

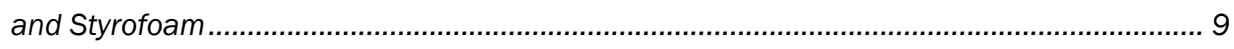

2.3.6 Other Considerations ........................................................................................ 12

2.4 Composting Approaches ......................................................................... 12

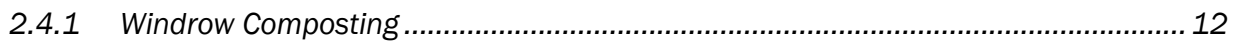

2.4.2 Static Pile Composting ..................................................................................... 13

2.4.3 In-Vessel Systems ........................................................................................... 15

2.5 Odor Control ................................................................................................ 16

2.6 Runoff \& Leachate Control........................................................................ 17

2.7 Composting in Louisiana .................................................................................... 17

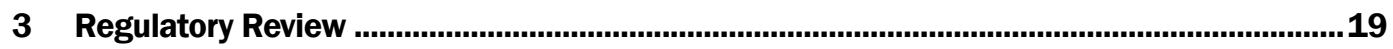

3.1 Type III Waste Management Facilities ........................................................... 19

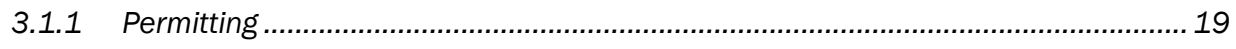

3.1.2 Waste that can be composted (LAC 33:VII, 723) .................................................... 20

3.1.3 Required Documents, Reports, and Records...................................................... 20

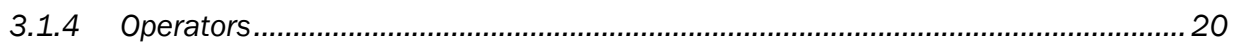


3.1.5 Required Plans for Type III facilities..................................................................... 20

3.1.6 Leachate \& Runoff Management for Type III Facilities............................................. 21

3.1.7 Security Requirements for Type III Facilities ........................................................... 21

3.1.8 Required Type III Composting Facility Components ................................................. 21

3.2 Compost Operational Parameters and Quality .................................................. 21

3.2.1 Metal Concentration of Finished Compost .............................................................. 21

3.2.2 Pathogen Reduction ......................................................................................... 22

3.2.3 Vector Reduction Requirements (for food chain applications only).........................22

3.3 Best Management Practices for Composting Yard Waste, Race Track Stable Bedding, or Woody Waste, or Agricultural Production/Processing Wastes.........................23

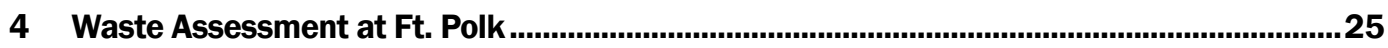

4.1 General Waste Generation at Military Installations................................................2 25

4.2 Review of Waste Generation Areas at Ft. Polk ....................................................26

4.2.1 Joint Readiness Training Area (JTRC) .................................................................... 26

4.2.2 Dining Hall Facilities (DFACS) ............................................................................. 28

4.2.3 Army \& Air Force Exchanges Services (AAFES) activities ..................................... 29

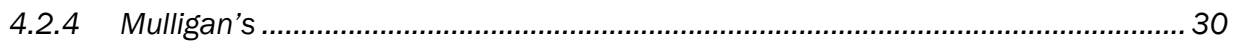

4.2.5 DFMWR Large Events ....................................................................................... 31

4.2.6 Department of Public Works (DPW) Roads and Grounds Maintenance ................... 32

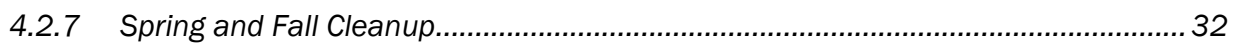

4.2.8 Wastewater Treatment Plants ............................................................................. 32

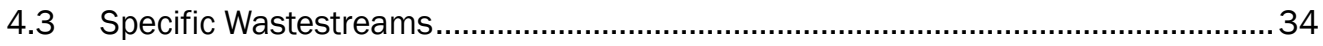

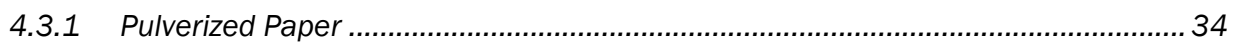

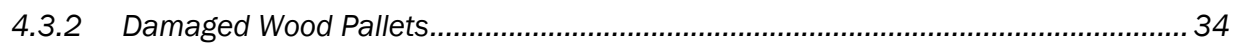

4.3.3 Vegetative Debris from Hurricane Rita ................................................................. 34

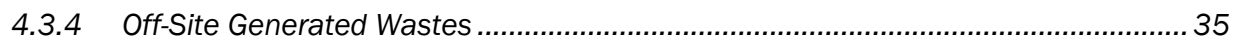

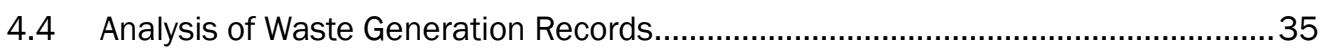

4.5 Summary of Waste Assessment ............................................................................. 38

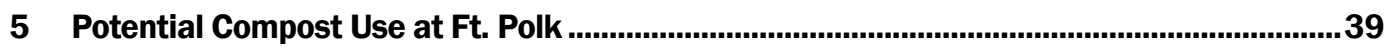

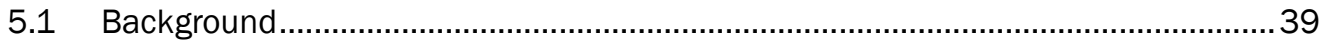

5.2 Application Rates and Techniques .......................................................................40

5.3 Department of Public Works (DPW) Roads and Grounds...................................... 41

5.4 Integrated Training Area Management (ITAM) .................................................. 41

5.5 Directorate of Family, Morale, Welfare, and Recreation..........................................42

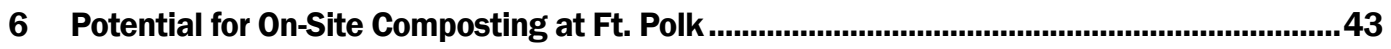

6.1 Location........................................................................................................ 43

6.2 General Layout and buildings needed for composting..............................................43

6.3 Equipment Required for Composting .............................................................43

6.4 Recommendations for a Ft. Polk Composting Operation .......................................45

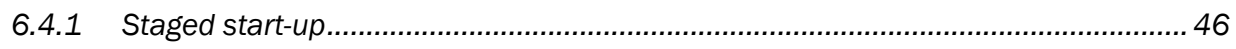

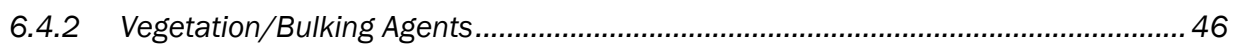

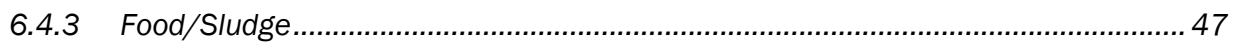

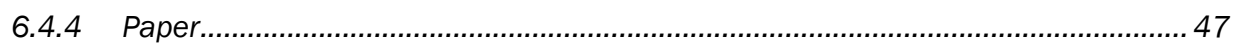

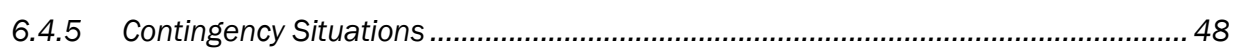




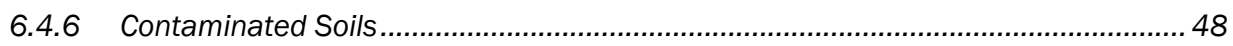

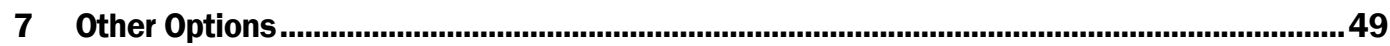

7.1 Outside the Fence Partnership Possibilities …......................................................... 49

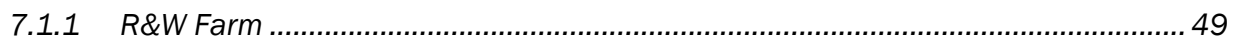

7.1.2 Partnerships with Local Communities ...................................................................50

7.1.3 Boise-Cascade Paper ........................................................................................... 50

7.2 Some Alternative Diversions to Implementing Composting ...................................51

7.2.1 Continued Management Practices..................................................................... 51

7.2.2 Direct application of Vegetative Material, Paper and Sludges as Soil

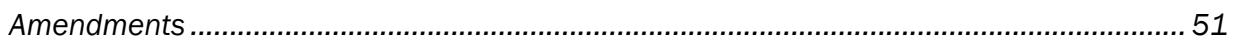

7.2.3 Alternatives for Food Wastes and Sludges ........................................................... 52

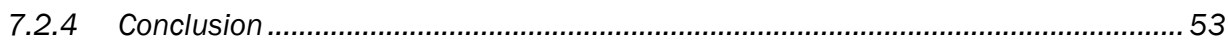

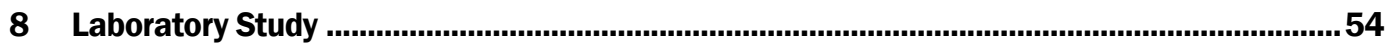

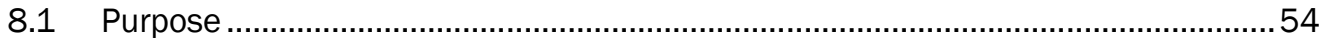

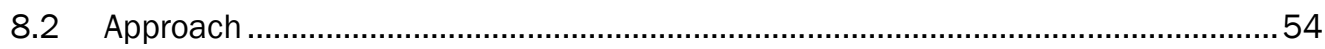

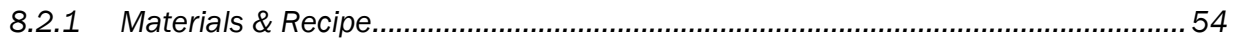

8.2.2 Reactor Setup \& Incubation ........................................................................ 56

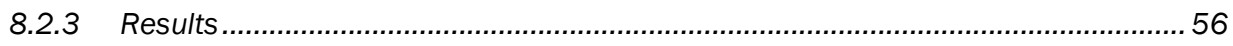

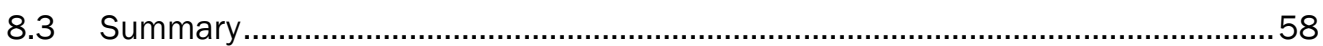

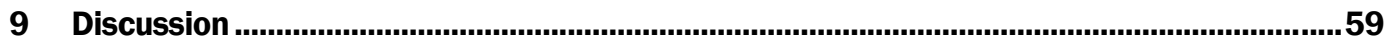

9.1 Implications to Other Army and DoD Installations and Army Net Zero Waste...........59

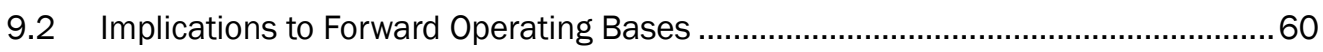

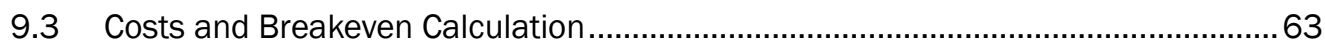

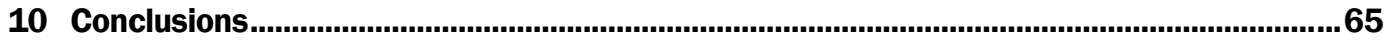

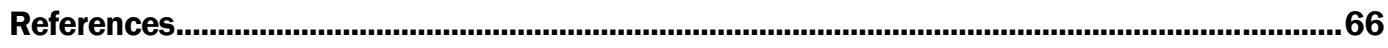

Appendix A: Carbon to Nitrogen Ratios for Various Waste Items (from USCC 2009) .................71

Appendix B: Moisture Contents of Various Feedstocks (from USCC 2009) ................................ 72

Appendix C: Summary Article on Biodegradable Plastic Replacements (prepared by

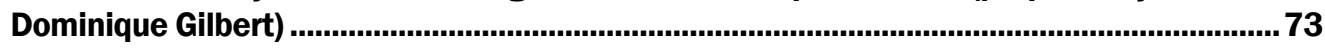

Appendix D: Phone meeting notes from discussion with Joey Breaux, Louisiana Office

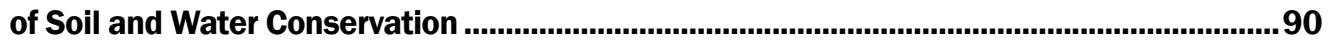

Appendix E: Cost Estimate for Preparing an On-Site Composting Operation (with references to R.S. Means construction estimating factors) .............................................91

Appendix F: Notes from Artemis Advantage, LLC. Regarding Off-Site Options.........................97

Appendix G: Breakeven calculations for five scenarios ...........................................................101

Report Documentation Page 


\section{Figures and Tables}

\section{Figures}

Figure 1. Food Waste Hierarchy. 8

Figure 2. PLA cups partially degraded after 30 days composting [From USCC (2009)] ................... 12

Figure 3. Windrow Composting. Windrow turner and a windrow compost pile.............................. 13

Figure 4. Schematic of a static pile composting operation............................................................. 14

Figure 5. Pictures of JBLM's forced air static pile composting operation.......................................... 15

Figure 6. In-vessel compost systems. The system on the left was the enclosed system tested at JBM-HH (described in NDCEE 2013a) and to the right is a simple enclosed system using a bag approach. .................................................................................................... 16

Figure 7. Typical composition of municipal solid waste (USEPA 2010)............................................ 26

Figure 8. Compostable service Items used by Mulligan's................................................................. 31

Figure 9. Sewage sludge in drying bed at American Water Operated Wastewater

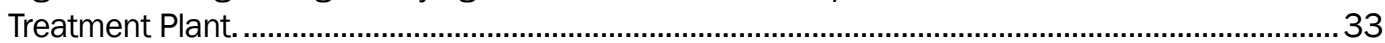

Figure 10. Aerial view of the proposed Chaffee Rd composting area................................................ 44

Figure 11. View of the proposed composting site looking Southeast toward Chaffee Rd. ................44 44

Figure 12. Idealized layout of a composting operation (courtesy of Sam Hunter, CERL).................. 45

Figure 13. Composting operations at R\&W Farm. .................................................................... 49

Figure 14. Materials used in study (from top left to right: Leaves, pine straw, sewage

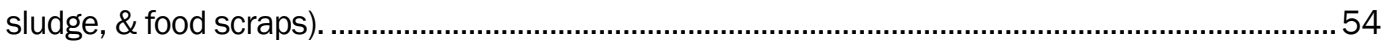

Figure 15. Denver Instruments moisture analyzer.................................................................... 55

Figure 16. Plastic bin containers used as a compost reactor........................................................56

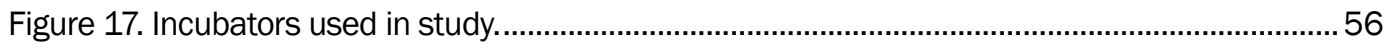

Figure 18. Comparison of Initial (left) and finished compost (right) consisting of leaves, pine straw, leaves, sludge, and food. Food is clearly visible in the initial compost (left), but almost completely degraded so as to be unrecognizable in the finished compost (right).

Figure 19. Finished (50 days) compost with pulverized paper (left) and with compostable products (right).

\section{Tables}

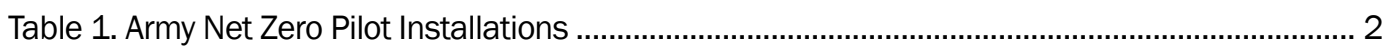

Table 2. C:N Ratios for key wastes identified at Ft. Polk (from USCC 2009, except sewage sludge, Rynk and Sailus 1992)

Table 3. Summary of compostable/biodegradable materials for service items. 7

Table 4. Cost comparison of typical plastic service items with biodegradable replacements.

Table 5. Cost differential of compostable products per serving (double waste assumes that the average user will use twice as many service items). 
Table 6. Composting operations in Louisiana identified via Internet searches (the authors acknowledge the contributions of Ms. Kathy Brewer and Ms. Christina Baker of Artemis Advantage, LLC., towards the creation of this list).

Table 7. Metal concentration levels of finished compost (mg/Kg dry weight).................................. 22

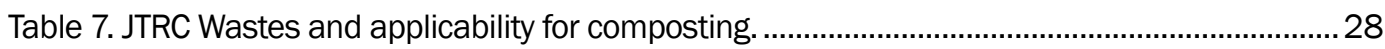

Table 8. DFAC wastes and applicability for composting................................................................29

Table 9. AAFES wastes and applicability for composting. ………...................................................30

Table 10. Mulligan's wastes and applicability for composting........................................................ 31

Table 11. DPW ground and maintenance wastes and applicability for composting..........................32

Table 12. WWTP wastes and applicability for composting..............................................................33

Table 13. Metal analysis (in $\mathrm{mg} / \mathrm{Kg}$ ) of sludge collected from one of the WWTP, operated by American Water at Ft. Polk. ND = Non-detect. (Selenium was measured later, and non-

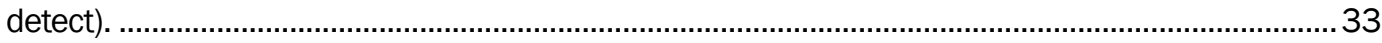

Table 14. Metal analyses $(\mathrm{mg} / \mathrm{Kg}$ ) of wood pallet samples from Ft. Polk. ND = Non-detect............34

Table 15. Solid waste generation at Ft. Polk via the SWARWeb database........................................36

Table 16. Detailed solid waste generation data for Ft. Polk from July 2011 to August 2012........... 37

Table 17. Diversion estimated from a 50:50 food waste, vegetation composting strategy. ..............38

Table 18. Equipment typically required for a forced air composting operation................................. 45

Table 19. Initial measurements and recipe used for the compost preparation. .............................55

Table 20. Volatile organic matter content and $\mathrm{pH}$ of compost reactors consisting of leaves,

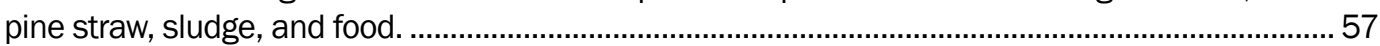




\section{Preface}

The work reported herein was conducted at the US Army Engineer Research and Development Center (ERDC), Environmental Laboratory (EL) in Vicksburg, MS and at the Construction Engineering Research Laboratory (CERL) in Champaign, IL. Funding for the work described in this report was provided by the Department of Public Works at Fort Polk, Louisiana.

Dr. Victor Medina and Michelle Wynter, EL; and Steven Cosper, Giselle Rodriguez, and Dr. Dick Gebhart, CERL, prepared this report. In-house review was provided by Dr. Catherine Thomas and Roy Wade. Curtis Fey of Army Environmental Command also provided a detailed review.

Tammy Veillon, Nathan “Jerry" Broussard, Ted Hammerschmid, Abi Franklin, and Philip St. Romain of Ft. Polk's Environmental Division were especially helpful in providing information. Dr. Charles Stagg, Chief of the Environmental Division, was also very supportive. The authors are appreciative of Kathy Brewer and Christina Baker, both of Artemis Advantage, LLC., who shared information about their efforts to develop a regional composting facility in the vicinity of Ft. Polk.

This study was conducted under the direct supervision of W. Andy Martin, Branch Chief, Environmental Engineering Branch (EP-E); Warren Lorentz, Division Chief, Environmental Processes and Engineering Division (EP); and Dr. Pat Deliman, Technical Director, Environmental Modeling and Assessment, EL.

At the time of publication, Dr. Beth Fleming was Director of EL, Dr. Ilker Adiguzel was Director of CERL, COL Jeffrey R. Eckstein was Commander of ERDC, and Dr. Jeffery P. Holland was Director of ERDC. 


\section{Unit Conversion Factors}

\begin{tabular}{|c|c|c|}
\hline Multiply & By & To Obtain \\
\hline Acres & $4,046.873$ & square meters \\
\hline acre-feet & $1,233.5$ & cubic meters \\
\hline cubic feet & 0.02831685 & cubic meters \\
\hline cubic inches & 1.6387064 E-05 & cubic meters \\
\hline cubic yards & 0.7645549 & cubic meters \\
\hline degrees Fahrenheit & $(F-32) / 1.8$ & degrees Celsius \\
\hline feet & 0.3048 & meters \\
\hline gallons (US liquid) & 3.785412 E-03 & cubic meters \\
\hline hectares & $1.0 \mathrm{E}+04$ & square meters \\
\hline inches & 0.0254 & meters \\
\hline microns & $1.0 \mathrm{E}-06$ & meters \\
\hline miles (US statute) & $1,609.347$ & meters \\
\hline pounds (mass) & 0.45359237 & kilograms \\
\hline pounds (mass) per cubic foot & 16.01846 & kilograms per cubic meter \\
\hline pounds (mass) per cubic inch & $2.757990 \mathrm{E}+04$ & kilograms per cubic meter \\
\hline pounds (mass) per square foot & 4.882428 & kilograms per square meter \\
\hline pounds (mass) per square yard & 0.542492 & kilograms per square meter \\
\hline square feet & 0.09290304 & square meters \\
\hline square inches & 6.4516 E-04 & square meters \\
\hline square miles & $2.589998 \mathrm{E}+06$ & square meters \\
\hline square yards & 0.8361274 & square meters \\
\hline tons (long) per cubic yard & $1,328.939$ & kilograms per cubic meter \\
\hline tons $(2,000$ pounds, mass $)$ & 907.1847 & kilograms \\
\hline tons ( 2,000 pounds, mass) per square foot & $9,764.856$ & kilograms per square meter \\
\hline yards & 0.9144 & meters \\
\hline
\end{tabular}




\section{Acronyms}
AAFES Army and Air Force Exchange Services
$\mathrm{C}: \mathrm{N} \quad$ Carbon to Nitrogen (ratio)
CERL Construction Engineering Research Laboratory
DFAC Dining Facility or Facilities
DFMWR Directorate of Family, Morale, Welfare, and Recreation
DoD Department of Defense
DPW Department of Public Works
EL Environmental Laboratory
ERDC Army Engineer Research and Development Center
FOB Forward Operating Base
FTE Full Time Employee
Ft. Fort
FY Fiscal Year
g, mg, Kg gram, milligram, kilogram
ha hectare(s)
ITAM Integrated Training Area Management
JBLM Joint Base Lewis McChord
JBMHH Joint Base Myer-Henderson Hall
JTRC Joint Readiness Training Area
LA Louisiana
LAC Louisiana Administrative Code
LDEQ Louisiana Department of Environmental Quality
LPDES Louisiana Point Discharge Elimination System
\%MC Percent Moisture Content
MRE(s) Meal(s) - Ready to Eat
MS4 Municipal Separate Storm Sewer Systems Permit
MSW Municipal Solid Waste(s)
ND Non-detect
NZW Net Zero Waste 


$\begin{array}{ll}\text { PLA } & \text { Polylactic Acid } \\ \text { PX } & \text { Post Exchange } \\ \text { SOUR } & \text { Specific Oxygen Uptake Rate } \\ \text { TOC } & \text { Total Organic Carbon } \\ \text { USCC } & \text { United States Composting Council }\end{array}$




\section{Introduction}

\subsection{Fort Polk}

Fort Polk is a US Army installation that was established in 1941 and is located in west central Louisiana (LA), approximately 10 miles east of Leesville, LA and 30 miles north of DeRidder, LA. The entire complex encompasses over 200,000 acres of land. Approximately 113,000 acres belong to the Army and serve as the main post in the northern area of the installation. To the south, the installation has 98,000 acres of National Forest land dedicated to intensive training. The population on post is approximately 9,792 military personnel and 13,232 civilians. Ft. Polk strives annually to be an Army Quality Installation, which means that it provides a secure, thriving community for soldiers, Army civilians, retirees, and their families.

Ft. Polk's primary mission is to support the Joint Readiness Training Center (JRTC). The JRTC hosts rotational units from all US military services for advanced contingency infantry and special operations training, adding an approximate 5,000 military personnel to the installation. The mission statement of the JTRC is to train soldiers and grow leaders to deploy, fight, and win. As a Power Projection Platform: the JTRC has critical missions to mobilize, validate, deploy, and redeploy Active, National Guard, and Army Reserve Forces.

The constant rotation of training units creates several unique waste challenges. The cost of processing and disposing of waste from the training areas is five times more than the average cost of processing and disposing of waste generated in other parts of the installation. Additionally, field training also generates large quantities of Meals - Ready to Eat (MREs). Currently, there are no diversion alternatives for these.

Despite the unique waste challenges at Ft. Polk, the staff and leadership are committed to finding appropriate solutions to these issues. Ft. Polk is engaged in the Army's sustainability efforts as part of the Army Net Zero Installation Strategy. In Fiscal Year (FY) 2011, the installation became one of the Army Net Zero Waste Pilot installations. 


\subsection{Army Sustainability Efforts}

The Army Net Zero Installation Strategy was announced in 2011. The main goal of the strategy is to integrate sustainability practices at the installation level to preserve the flexibility to operate in constrained circumstances, either economical or environmental. The first step in the strategy was to select the Net Zero Installation Pilots and divide the effort into three categories: Net Zero Energy, Net Zero Water, and Net Zero Waste (NZW). A Net Zero Energy installation is defined as an installation that produces as much energy on-site as it uses. A Net Zero Water installation is an installation that limits the consumption of fresh water resources and returns the water back to the same watershed. A Net Zero Waste installation is an installation that reduces, reuses, and recovers waste streams, converting them to resource value without using landfill. Pilot installations should achieve these goals by FY 2020. The Pilot installations (Table 1) were selected after an evaluation process for which several installations submitted application packages.

Table 1. Army Net Zero Pilot Installations.

\begin{tabular}{|c|c|c|}
\hline Net Zero Energy & Net Zero Water & Net Zero Waste \\
\hline $\begin{array}{l}\text { - } \text { Fort Detrick, MD } \\
\text { - } \text { Fort Hunter Liggett, CA } \\
\text { - Kwajalein Atoll, Rep. of the } \\
\text { Marshall Islands } \\
\text { - } \text { Parks Reserve Forces } \\
\text { Training Area, CA } \\
\text { - Sierra Army Depot, CA } \\
\text { - } \text { West Point, N.Y. }\end{array}$ & $\begin{array}{ll}\text { - } & \text { Aberdeen Proving } \\
& \text { Ground, MD } \\
\text { - } & \text { Camp Riley, OR } \\
\text { - } & \text { Fort Buchanan, PR } \\
\text { - } & \text { Fort Riley, KS } \\
\text { - } & \text { Joint Base Lewis- } \\
\text { McChord, WA } \\
\text { - } \text { Tobyhanna Army Depot, } \\
\text { PA }\end{array}$ & $\begin{array}{ll}\text { - } & \text { Fort Detrick, MD } \\
\text { - } & \text { Fort Hood, TX } \\
\text { - } & \text { Fort Hunter Liggett, CA } \\
\text { - } & \text { Fort Polk, LA } \\
\text { - } & \text { Joint Base Lewis-McChord, } \\
& \text { WA } \\
\text { - } & \text { US Army Garrison } \\
& \text { Grafenwoehr, Germany. }\end{array}$ \\
\hline \multicolumn{3}{|c|}{ Integrated Installations (Net Zero Energy, Water and Waste) } \\
\hline \multicolumn{3}{|l|}{$\begin{array}{ll}\text { - } & \text { Fort Bliss, TX } \\
\text { - } & \text { Fort Carson, CO }\end{array}$} \\
\hline
\end{tabular}

\subsection{Net Zero Waste (NZW)}

The concept of NZW simply states that no waste should go to landfill over the course of one year. A combination of different waste management practices along the life cycle of the installation should be applied to accomplish this goal. These practices are divided in two main components: waste minimization and waste diversion. The waste minimization component of the Net Zero Strategy encourages the installations to reduce waste at the source by engaging in sustainable purchasing of materials that 
generate less waste, have less packaging, are reusable and recyclable, etc. The second component, waste diversion, refers to the processes and technologies the installation can use to prevent its waste from going to the landfill. Some examples of alternatives to landfill disposal are recycling, composting, and waste to energy technologies, etc. 


\section{Composting - State of the Art}

\subsection{Composting}

Composting is a biological treatment process for organic constituents. This process involves the placing of organic material in a pile with sufficient water and air to stimulate microbial activity. The pile creates insulation, which causes both a rise in temperatures and an increase in biological activity. The temperature gradient within the pile stimulates air flow as the pile becomes a self-sustaining reactor.

Composting is an aerobic and thermophilic process, meaning that it requires first oxygen then elevated temperatures. The process results in a partial transformation of complex organic constituents, as opposed to complete mineralization. As a result of these transformations, offensive characteristics (such as odor) are removed, pathogenic microorganisms are destroyed, and nutrient availability is increased.

The goal of composting is to produce a residual that is amenable to land application as a nutrient source or soil amendment. Although technically a very wide range of organic materials can be successfully composted, aesthetic considerations must be considered. For example, a biodegradable plastic can undergo sufficient reactions in a compost pile, but still appear to be in its original form, such as in the form of a plastic fork. One way to address this is to grind the materials or the resultant compost so that partially degraded substances no longer look recognizable (and thus objectionable) after the composting reaction. Of course, this grinding does increase the cost of the operation.

\subsection{Operating Parameters}

Successful composting requires a balance between several key parameters. The greatest cause for failure in composting operations is odor, due to improper operation. Foul odors can cause issues with neighbors; they are also an indicator of improper treatment. Other composting failures can include failure to deactivate pathogenic microorganisms. By maintaining proper operating parameters, odors are contained and composting success is assured. 


\subsubsection{Aerobic Conditions}

With few exceptions, composting is an aerobic process (Epstein 1997). This means that enough oxygen must be present to promote aerobic respiration. If aerobic conditions are not maintained, anaerobic digestion takes over, slowing down the biological activity. Additionally, anaerobic reactions tend to be more odorous.

Aerobic conditions are maintained by promoting good air flow through piles. One way to maintain such air flow is to incorporate structurally rigid, slowly degrading pieces - like wood chips - into piles. This will create a porous structure within composting materials and encourage air movement. If the compost has a good, porous structure, the temperature gradients may be sufficient to promote aerobic degradation. However, if high organic materials are added, such as food waste or sludge, passive aeration will likely not be adequate, and the piles will require periodic turning or forced air to increase aeration.

\subsubsection{Water Content}

Water content is another key parameter (Epstein 1997). Biological activity requires water. However, too much water can clog pore spaces and impede air flow, creating anaerobic conditions. Fifty to sixty percent moisture content by wet weight is generally considered optimal. Water can generally be applied to compost if needed.

\subsubsection{Thermophilic Conditions}

Thermophilic temperatures ( 50 to $70^{\circ} \mathrm{C}\left(131\right.$ to $\left.160^{\circ} \mathrm{F}\right)$ ) promote composting as well as faster biological reactions. These conditions are also critical for the deactivation of pathogens, and the promotion of air movement and aerobic conditions in the pile. In fact, $50^{\circ} \mathrm{C}\left(131^{\circ} \mathrm{F}\right)$ is considered a threshold temperature at which most pathogens are destroyed. Temperature gradients resulting from themophilic conditions promote air movement in the pile, assisting in the maintenance of aerobic conditions.

Several features of the compost pile work to create high temperatures. First, high biological activity generates heat. Incorporating easily biodegradable materials into the compost recipe will promote thermophilic conditions. Similarly, aerobic reactions generate more heat than anaerobic reactions. Thus, creating and maintaining aerobic conditions is critical. Finally, 
creating insulation can allow temperatures to rise. Generally, compost piles on the order of 1 to 2 meters in depth allow for the right combination of insulation to airflow. Thicker piles may have issues maintaining even air flow and aerobic conditions. Enclosed, or in-vessel, reactors can also be useful for insulating compost and maintaining elevated temperatures.

\subsection{4 pH}

Very low $\mathrm{pH}(<3)$ or high $\mathrm{pH}(>11)$ tend to stop aerobic biological activity. Optimal conditions are near neutral (between 6 and 9). However, most solid wastes have $\mathrm{pH}$ near neutral and biological reactions in most composting settings are relatively buffered, making $\mathrm{pH}$ control generally very easy for most composting operations.

\subsection{Optimal Compost Recipes}

A compost recipe is a mixture of mostly organic feedstocks routinely used by a composting operation. A bad recipe can result in failure of the compost operation. A good recipe can contribute greatly to success. Trial and error may be needed early in a new composting operation, but a good recipe can usually be developed in a short period of time.

\subsubsection{Carbon: Nitrogen Ratios}

Composting aims for transformation of most of the organic materials rather than complete mineralization. Thus, the carbon:nitrogen $(\mathrm{C}: \mathrm{N})$ ratio for composting tends to be relatively high as compared to other biodegradation processes that require higher nitrogen levels for complete degradation (Epstein 1997). Composting works best on feedstocks with an aggregate C:N ratio of 30 to 45:1.

Composting can accommodate a range of organic materials. By balancing organic materials with low C:N ratios (such as food and sludge) with those with high ratios (like wood and paper), effective treatment can be accomplished. Nutrient and/or carbon additions can help balance ratios (Liang et al. 2006), although it can reduce some of the low cost benefits of composting due to the costs of these additives.

A detailed description of compostable waste streams at Ft. Polk is discussed in the following sections. Table 2 summarizes key wastes and $\mathrm{C}: \mathrm{N}$ ratios associated with each. Appendix 1 is an expanded list of $\mathrm{C}: \mathrm{N}$ ratios for a wider variety of potential waste products. 
Table 2. C:N Ratios for key wastes identified at Ft. Polk (from USCC 2009, except sewage sludge, Rynk and Sailus 1992).

\begin{tabular}{|l|l|l|l|}
\hline Material & C:N Ratio & \% Water Content & Comment(s) \\
\hline Cardboard & 560 & 8 & $\begin{array}{l}\text { From damaged } \\
\text { cardboard or pizza boxes. }\end{array}$ \\
\hline Mixed Food Wastes & $14-16$ & 69 & \\
\hline Green vegetation & $17-80$ & 15 to 72 & $\begin{array}{l}\text { Grass, shrub trimmings, } \\
\text { leaves. }\end{array}$ \\
\hline $\begin{array}{l}\text { Dry or woody } \\
\text { vegetation }\end{array}$ & $100-1300$ & $<15$ & \\
\hline Paper & $125-180$ & 19 & \\
\hline $\begin{array}{l}\text { Digested wastewater } \\
\text { treatment sludge }\end{array}$ & 16 & 10 to 80 & \\
\hline
\end{tabular}

\subsubsection{Water Content}

As mentioned above, between 50 to $60 \%$ water content by weight is optimal. Food and sludges tend to have high water content, while paper and wood have low. By balancing feedstocks, the target water content can be obtained. Table 2 has typical water content for key wastes identified at Ft. Polk and Appendix 2 provides typical water content for a wider range of waste materials. Water can be easily added, if needed.

\subsubsection{Food}

Because hunger remains a problem throughout the world, including at certain socio-economic levels in the United States, management of food waste is a critical issue. USEPA (2012) has developed a ranking system for surplus food (Figure 1). Composting is the $5^{\text {th }}$ level on the hierarchy, but is perhaps second only to source reduction in importance, since two of the levels (feed people, feed animals) require preservation and may have health issues associated with them, and since industrial uses are limited to oils, fats, and grease.

Ft. Polk has made a conscious decision to reduce food waste; however, it is a challenging task because soldiers must be fed adequately, which involves providing food in excess. Furthermore, hospital operations (there is a hospital on the installation) typically waste significant amounts of food as patients are often unable to eat the meals provided. Ft. Polk endeavors to give away surplus food whenever possible to worthy organizations like the fire and police departments; however, some regulations limit the amount of food items that can be donated. 
Figure 1. Food Waste Hierarchy.

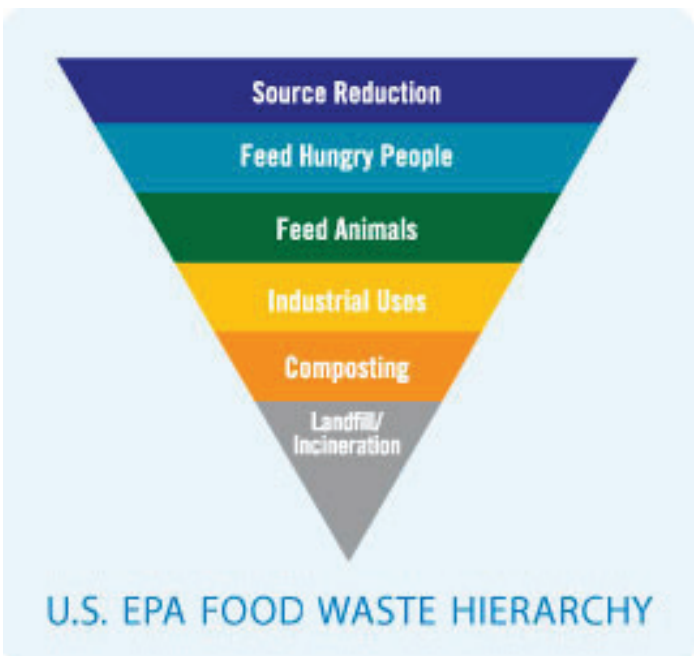

Food waste is a valuable but challenging material for composting operations (Chang and Hsu 2008, USCC 2009). This material is valuable because it provides moisture to the system and is high in nitrogen, an important nutrient in fertilizers. Handling food waste is challenging because it is putrescent, causing foul odors. It also can attract vermin. However, mixing composting with food can eliminate odor, pest, and pathogenic issues; it also allows for the beneficial reuse of these valuable materials, including the production of new food via agricultural processes. Mixing composting with food saves landfill space and decreases the formation of undesirable landfill gases, including methane, a strong greenhouse gas.

Careful planning is needed for composting operations that include food waste. Generally, once food is incorporated into a compost pile (as part of an effective recipe), the odor issue comes under control. Coordination of food waste deliveries is necessary so that the food waste can be incorporated quickly. Storage of food invites severe odor problems and vermin issues.

Food availability also might affect the choice of composting technology. As discussed in section 2.4, windrow composting, which involves periodic turning of compost piles, can result in increased release of odor. In-vessel systems, on the other hand, offer greater odor control (Donahue et al. 1998, Kim et al. 2008).

\subsubsection{Paper}

It is generally agreed that recycling is the best fate for paper. Ft. Polk has instituted an aggressive paper recycling program. However, many paper 
products cannot be recycled. This includes consumer-contaminated paper products, like napkins, food service material, and sanitary materials. It also includes coated paper products, like waxed paper, and most paper board materials, like cereal boxes. In the Army, sensitive documents typically undergo pulverization, which makes the fibers unsuitable for recycling. Nevertheless, papers of all kinds have been used in compost. All evidence suggests that paper can be successfully composted, and that it could actually improve the quality of compost (USCC 1995). Paper can also provide wicking and binding effects that help hold water and nutrients in the food zone.

\subsubsection{Biodegradable/Compostable Replacement Materials for Plastics, Rubber, and Styrofoam}

Plastic and Styrofoam materials are challenging to compost because they do not degrade. Grinding can be one way to incorporate these materials. Another option is the use of biodegradable or compostable replacements. In some cases, paper products can be used in exchange for these moredifficult-to-compost products. However, compostable paper-based products do not always meet the service needs of the food vendor. To that end, there has been some development in biodegradable and compostable replacements. Three types dominate: bioplastics, starch-based plastics, and bagasse. Bioplastics use a polymer based on polylactate acid (PLA) (Hoppenheidt and Trankler 1995, Copinet et al. 2004, Sarasa et al. 2009, USCC 2009). These materials look and perform a lot like traditional, petroleum-based plastics; however, they are usually not as durable and robust as petroleum-based plastics (Copinet et al. 2004, Rippey 2012). Studies indicate that bioplastics are much more likely to degrade with exposure to UV light and high temperatures. Bioplastics are, therefore, not used for long-term storage, like drinking water bottles. Starched-based plastics, particularly those from corn and potato starch, tend to make a weak plastic, usually suitable for light duty items. Lastly, bagasse is a highly fibrous plant material associated with sugar cane. It can be made into heavy duty plates and bowls that are heat resistant, though these products often lack the suppleness of more traditional plastics (Table 3). Appendix 3 gives a more detailed summary of biodegradable options. 
Table 3. Summary of compostable/biodegradable materials for service items.

\begin{tabular}{|l|l|l|}
\hline Material & Typical Items & $\begin{array}{l}\text { Processing } \\
\text { Time }\end{array}$ \\
\hline sugarcane bagasse & bowls, plates, cups--hot and cold use & 90 days \\
\hline corn PLA, for cold uses & $\begin{array}{l}\text { cold cups, straws and deli-style food } \\
\text { containers }\end{array}$ & 180 days \\
\hline corn PLA, heat-resistant & soup cups, hot use utensils & $6-12$ months \\
\hline corn or potato starch & utensils, hot and cold uses & $6-12$ months \\
\hline $\begin{array}{l}\text { corn starches, resins and } \\
\text { polymers }\end{array}$ & trash bags & $30-90$ days \\
\hline corn starch & packaging peanuts & $<30$ days \\
\hline
\end{tabular}

From USCC (2009)

Biodegradable plastics should be used only after careful consideration. First, these materials are generally more expensive than non-biodegradable, petroleum-based plastics. Table 4 compares the cost of "green" (biodegradable) products versus conventional items (Rippey 2012). In only one case did the green product cost less than the non-recyclable alternative. From a percentage point of view, the cost differential between a green product and a traditional plastic product can be up to 28 times higher (see comparison of fork costs). However, if we consider the differential from a cost-per-meal basis, we come up with about $\$ 0.60$ per meal, which seems relatively modest (Table 5). Furthermore, as these materials are adopted, it is reasonable to expect that their costs will get lower due to economy of scale, particularly since standards are being implemented that will require Federal purchasers to buy "green" products, despite these cost differences (Rippey 2012).

Finally, most petroleum-based plastics can be recycled (although Styrofoam is generally not recycled). Polyester-based plastic containers and bags can be broken down into fibers, which can be recycled to make clothes, bottles, thread, and other plastic products (Bartle 2011). Therefore, a reasonable strategy would be to use petroleum-based plastics for materials not affected by consumer contamination, such as shopping bags and water bottles, and promote recycling of these materials. Bioplastics and biodegradable alternatives could be used whenever possible to replace plastics and styrofoams for direct food service that results in consumer contamination, which would greatly complicate recycling.

If biodegradable items are to be used, a strategy should be developed for these items to be separated from non-biodegradable items in the waste 
stream. Non-biodegradable, petroleum-based plastics usually can be recycled and/or potentially converted to energy. Biodegradable plastics, however, are not recycled and are poor waste to energy sources (Rippey 2012).

Table 4. Cost comparison of typical plastic service items with biodegradable replacements.

\begin{tabular}{|c|c|c|}
\hline Item & Unit Price (\$) & $\begin{array}{l}\text { Price difference (Green } \\
\text { - Conventional) }\end{array}$ \\
\hline $\begin{array}{l}9 \times 9 \text { three compartment ivory } 3 \text { in hinged lid Bagasse } \\
\text { (biodegradable paper) }\end{array}$ & 0.256 & \multirow[t]{2}{*}{0.137} \\
\hline 9x9 three compartment white 3.25 in hinged lid Foam & 0.119 & \\
\hline 6x6 1 compartment clear 3 in hinged lit. Biodegradable PLA plastic & 0.149 & \multirow[t]{2}{*}{0.028} \\
\hline 6x6 1 compartment clear 3 in hinged lit. Plastic & 0.121 & \\
\hline 16 oz Cold clear green stripe. Biodegradable PLA plastic. & 0.084 & \multirow[t]{2}{*}{0.019} \\
\hline 16 oz Cold clear. Plastic. & 0.065 & \\
\hline Medium weight beige fork. Biodegradable corn starch plastic. & 0.028 & \multirow[t]{2}{*}{0.018} \\
\hline Medium weight white fork. Polypropolyene plastic. & 0.010 & \\
\hline 10 in 3-compartment plate. Bagasse (biodegadable paper) & 0.085 & \multirow[t]{2}{*}{-0.071} \\
\hline 10.25 in 1-compartment black round plate. Foam. & 0.156 & \\
\hline 7.75 in Jumbo clear, wrapped straw. Biodegradable PLA plastic. & 0.015 & \multirow[t]{2}{*}{0.011} \\
\hline 7.75 in Jumbo clear, wrapped straw. Polypropolyene plastic. & 0.004 & \\
\hline
\end{tabular}

Table 5. Cost differential of compostable products per serving (double waste assumes that the average user will use twice as many service items).

\begin{tabular}{|c|c|c|c|c|c|c|}
\hline & \multicolumn{2}{|c|}{ Cost Diff } & no. & \multicolumn{3}{|c|}{ Total Cost } \\
\hline Plate & $\$$ & 0.07 & & 1 & $\$$ & 0.07 \\
\hline 3 utensils & $\$$ & 0.02 & & 3 & $\$$ & 0.05 \\
\hline Cup & $\$$ & 0.02 & & 1 & $\$$ & 0.02 \\
\hline Straw & $\$$ & 0.01 & & 1 & $\$$ & 0.01 \\
\hline Container & $\$$ & 0.14 & & 1 & $\$$ & 0.14 \\
\hline & & & Total & & $\$$ & 0.29 \\
\hline Assume $d$ & louk & was & tage & & $\$$ & 0.58 \\
\hline
\end{tabular}

Even if biodegradable plastics are adopted, it is important to be aware that they typically degrade slowly. Figure 2 is a picture of biodegradable plastic (PLA) cups after 30 days in a composting system. They still look like cups, and will not be acceptable for most soil applications. In many instances, this issue can be addressed simply by grinding the materials, and over a long period of time, biodegradation percentages in excess of $60 \%$ can be obtained (Sarasa et al. 2009). 
Figure 2. PLA cups partially degraded after 30 days composting [From USCC (2009)].

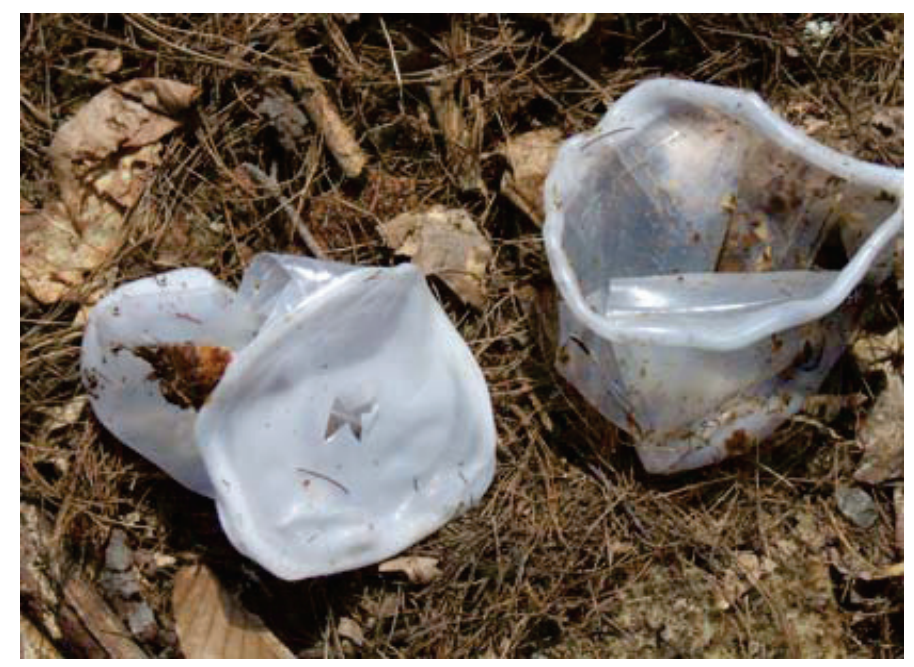

\subsubsection{Other Considerations}

Like the structurally rigid material mentioned above, large, rigid materials can also help maintain good air flow. Most recommendations are for limiting oils and fats in the waste stream to less than $5 \%$ (USCC 2009). Meats and bones in the waste stream require high temperatures to compost appropriately, ( $>131 \mathrm{~F}\left(50^{\circ} \mathrm{C}\right)$ ). Although virtually any organic material can be composted, some materials undergo very slow reactions and remain largely unchanged during most composting operations. These include plastics, leathers, and rubber. However, grinding can be used to transform materials into smaller pieces so that they are more aesthetically pleasing.

Care should be taken to limit hazardous or toxic chemicals or materials in compost, as these can affect its use as a soil amendment. In addition, metals remain unchanged throughout the composting process, and should be avoided as much as reasonably possible. Organic compounds that are regulated by the Resource Conservation and Recovery Act (RCRA) or other similar organics that might be considered as soil contaminants should also be limited, although composting tends to be effective at degrading many contaminants, including several persistent ones. (Epstein 1997).

\subsection{Composting Approaches}

\subsubsection{Windrow Composting}

Windrow composting is an open air composting approach in which the compost material is laid out in the open, and periodically turned or 
physically mixed to aerate the material (Haug 1993, Rynk and Sailus 1992). The compost is typically set up in elongated, triangular-shaped piles, which allows for easy access and turning (Figure 3). While there are specialized machines made specifically for turning windrows, less expensive options exist with soil or earth-moving equipment, including agricultural tractors, bulldozers, and skip loaders.

Figure 3. Windrow Composting. Windrow turner and a windrow compost pile.

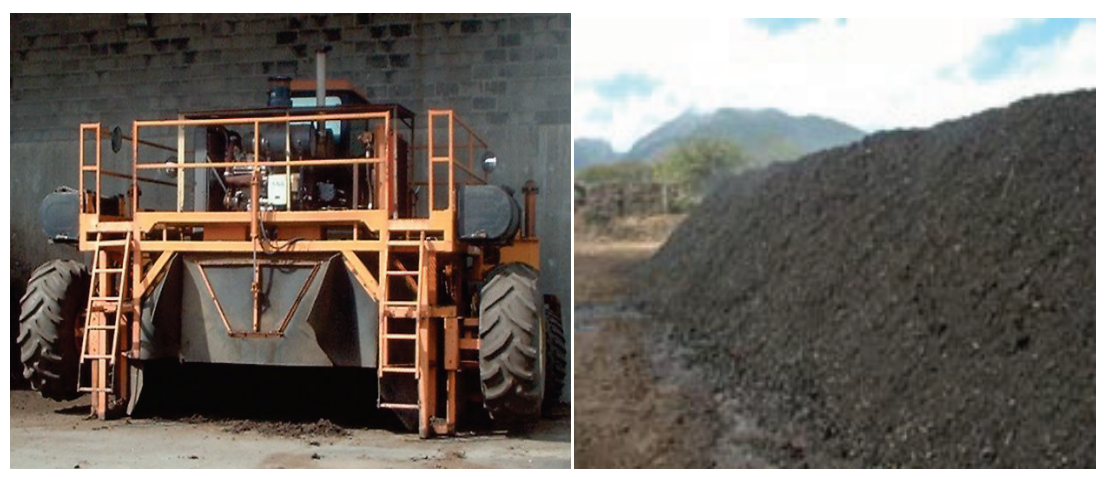

Windrow composting is generally considered the simplest approach to composting. It is easy to implement, requires very little equipment beyond what is needed for turning the windrows, and is generally very effective. Because the material is turned, it is easy to mix in amendments and modify the process after operation begins.

Windrow composting generally has the greatest space requirements, as windrows can be long and there must be enough area to accommodate them. In addition, the turning process can result in periodic release of high odors.

Windrow composting is very commonly performed on farms because space is typically not an issue, odors are not a major problem, and farms already have the necessary equipment for the operation. In fact, the composting operation at the R\&W Farm in Allen Parish (which currently receives food wastes from Ft. Polk, see section 7.1.1) is a windrow operation.

\subsubsection{Static Pile Composting}

In a static pile, the compost material is not physically turned. Rather, air is circulated within the pile (Rynk and Sailus 1992). This can be accomplished passively in some cases, relying on the heat differential within the pile to create the air currents. However, in most cases, air movement is forced via a vacuum or blower through a piping system to ensure good air-flow through the pile. 
Figure 4 is a schematic of a typical forced air pile system. Piping is used to distribute air through the pile. The air can be either drawn in by a vacuum system, or forced in using a blower (most blowers can be attached to work either in a vacuum or in forced air mode). The pile is covered by a layer of finished compost, which absorbs and degrades odors (see section 2.5). In a vacuum operation, a simple air pollution control device can be used to treat the gases: a compost biofilter usually works well.

Figure 4. Schematic of a static pile composting operation.

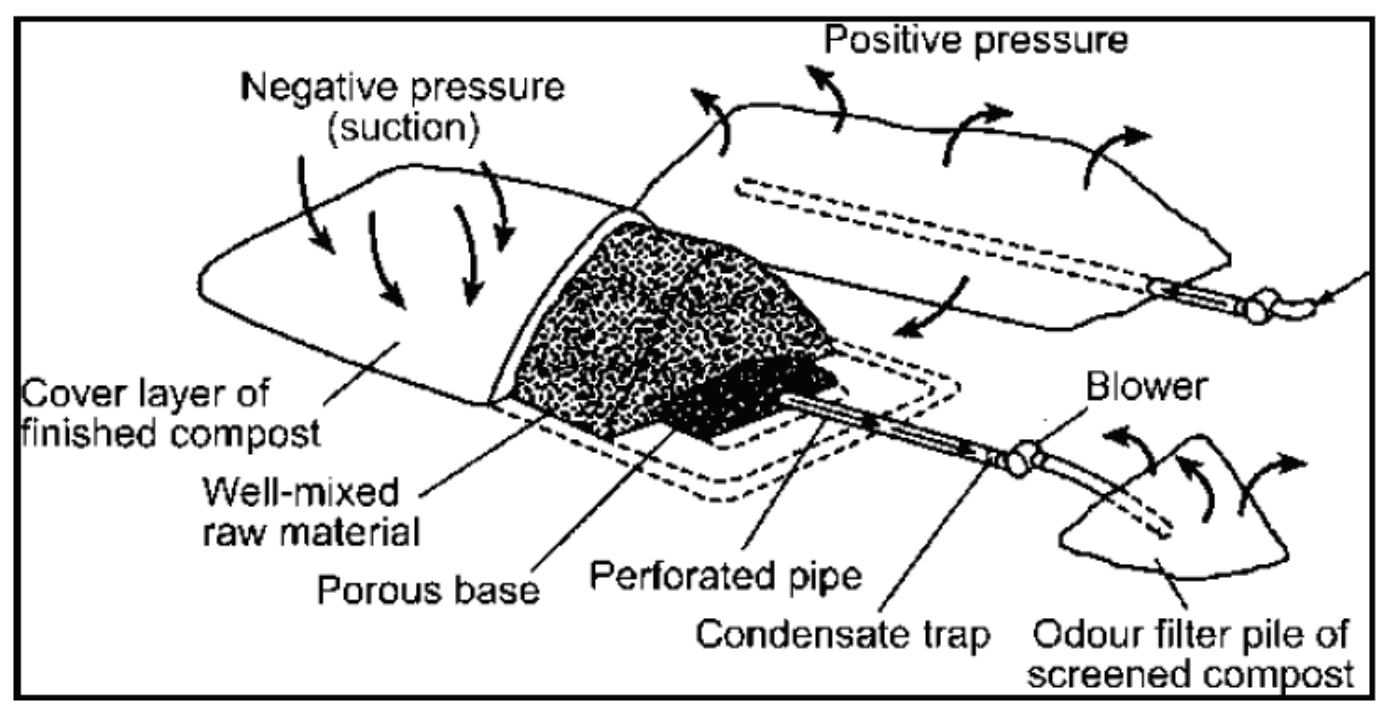

Static piles are somewhat more complex in terms of set up than windrows. Like windrow composting, equipment is needed to move the compost materials. In addition, piping is typically placed within the pile and a blower/vacuum is attached to the piping. Designing and installing the piping system is more complex than simply turning the pile. Once a static pile is set up, it is not easy to make changes to its operation.

However, static piles are not moved once they are set up, so the operation requires less space (it is possible to turn piles in place with modern windrow turners, but these also require space to operate). Without having to turn piles over, it is also possible to make the piles higher, thus saving more space. It is easier to set up a static pile operation so it remains covered. And if no turning is necessary, it is usually easier to control odors. Joint Base Lewis McCord (JBLM) uses a forced air static system for their large composting operation (Figure 5). 
Figure 5. Pictures of JBLM's forced air static pile composting operation.

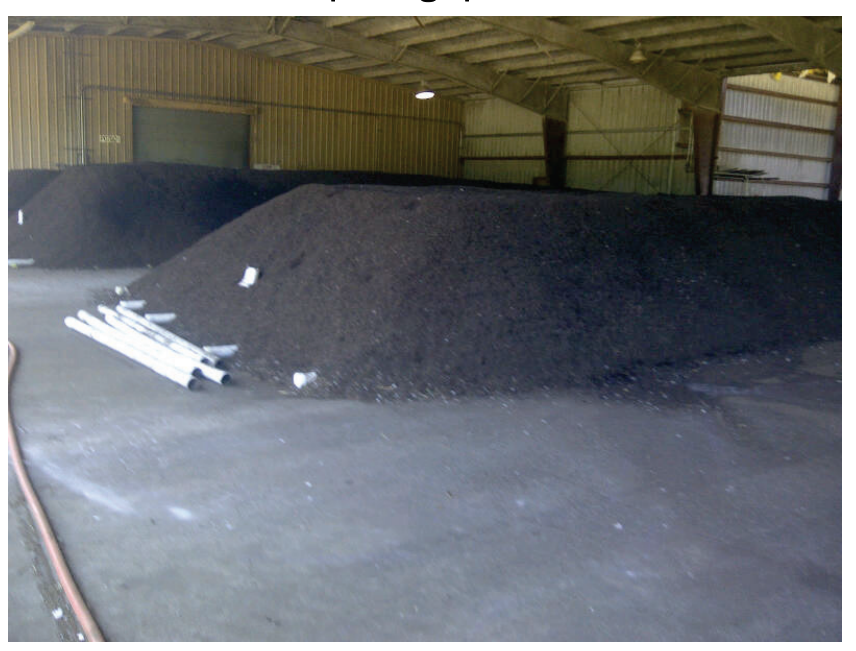

\subsubsection{In-Vessel Systems}

In-vessel systems can best be described as enclosed reactors (Donahue et al. 1998, USEPA 2000, Kim et al. 2008, Bonhotal et al. 2011). These enclosed reactors allow for more effective aeration and temperature control than other systems, resulting in faster composting times. These systems also have a smaller footprint, are closed to weather, and can provide complete odor control. Furthermore, their operation can be semiautomated, allowing for minimal staffing needs.

While open systems like windrows and static piles are batch systems, usually requiring that composting operations occur in stages, closed systems are continuous flow, in which feedstocks can be added as they are received. This is particularly attractive with putrescent materials, like food, dead animals, and sludge. A mobile, in-vessel composting reactor was recently demonstrated at Joint Base Myer-Henderson Hall (JBMHH) (Keysar et al. 2013, NDCEE 2013a, 2013b). Figure 6 is comprised of pictures of in-vessel systems. This system, which would be suitable for treating the food and related wastes of 250 men (Keysar et al. 2013), had an estimated cost of $\$ 90,000 .^{1}$

Though often more efficient than open systems, closed systems can be more expensive. Though there are simple closed systems available on the market, these may have only marginal benefits as compared to the open approaches described above. Generally, a closed system reactor is sized for

1 Personal communication. Keysar, E., Sustainability Analyst, Concurrent Technology Corporation 
a specific range of loading. Changes to the amount of compost a specific reactor is to handle can often require the purchase of another reactor as compared to an open system where the solution is simply to begin another pile/windrow.

Figure 6. In-vessel compost systems. The system on the left was the enclosed system tested at JBM-HH (described in NDCEE 2013a); to the right is a simple enclosed system using a bag approach.
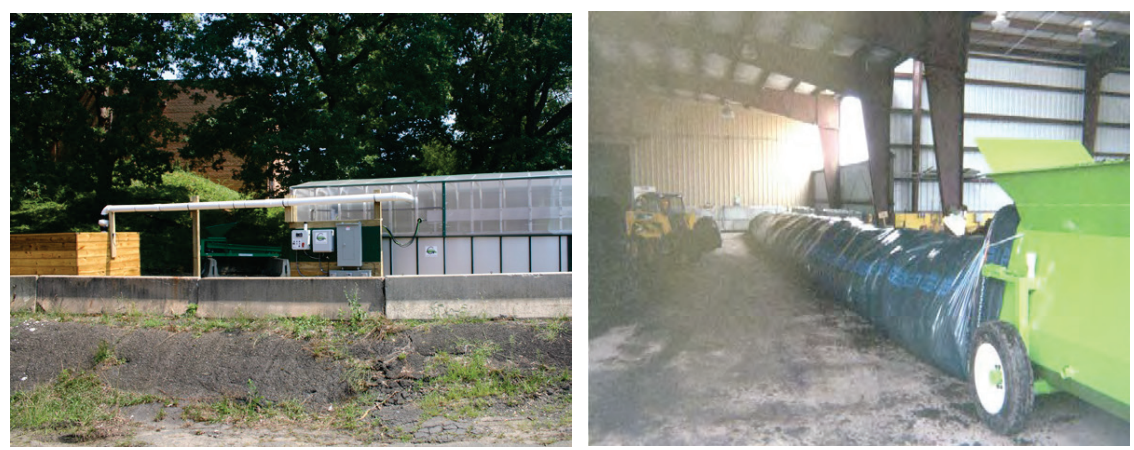

\subsection{Odor Control}

Odor control is critical for a composting operation to achieve success (Epstein 1997, Komilis and Ham 2000). Fortunately, a few key parameters can assist in controlling these issues. First, siting of the composting operation is important. A site that is relatively remote can reduce odor concerns significantly. Siting can also accommodate for prevailing wind conditions, which may also be a key factor in odor complaints.

Many odor issues actually originate from the storage of compost feedstock materials, as opposed to the operation itself. Largely vegetative compost will have less odor issues than materials that can putrefy, such as food or sludges. If items like food or sludges are included in the composting operation, then the system should include planning that allows for these materials to be quickly placed into a compost pile. This will reduce odor opportunities. Another option is to simply limit the composting operation to materials less susceptible to putrification, like vegetative sources.

As previously mentioned, maintaining aerobic conditions is critical to preventing odors in compost piles. Furthermore, different composting approaches can be correlated with different amounts of odor release. Operations that rely on turning or mixing for aeration generally have more potential for releasing odors than those systems that use static piles 
(provided that these are properly aerated). In-vessel compost reactors provide still greater odor control capabilities.

Interestingly, finished compost is an excellent odor control material, as it readily adsorbs odor-causing compounds and promotes their biodegradation (Devinny et al. 1999). Finished compost can be applied to the surfaces of open compost piles to control odors or can be used in simple, inexpensive biofilter reactors to control odors that are created from forced air (vacuums) or within in-vessel systems.

\subsection{Runoff \& Leachate Control}

Composting operations need to maintain excellent surface runoff and leachate (vertical movement to groundwater) control. Runoff can be managed by contouring the site so that any runoff goes into engineered drainages, which limits exposure of runoff water to composting areas. Drainage into sediment traps or retention ponds can remove unwanted compostables from surface water drainages. Vegetative buffers can be effective at reducing particulates in surface water runoff.

Leachate is best controlled by limiting its generation. Site selection can be a factor, as sites with low permeability soils can reduce leachate generation. In addition, paving portions of the site where compostable materials are staged or compost is cured can significantly limit leachate formation. Maintaining vegetation on unpaved areas can increase evapotranspiration, reducing water migration as leachate.

\subsection{Composting in Louisiana}

Table 6 summarizes known composting operations in the state of Louisiana that the authors identified via internet searches (except for R\&W Farms). There are likely other facilities throughout the state, including many small farming operations, but it does suggest that largescale composting is relatively sparse throughout the state. 
Table 6. Composting operations in Louisiana identified via Internet searches (the authors acknowledge the contributions of Ms. Kathy Brewer and Ms. Christina Baker of Artemis Advantage, LLC, towards the creation of this list).

\begin{tabular}{|l|l|l|}
\hline Name & Location & Comments \\
\hline $\begin{array}{l}\text { Dean Domingues } \\
\text { Compost Facility }\end{array}$ & Lafayette Parish & $\begin{array}{l}\text { Treats yard wastes from the City of Lafayette and } \\
\text { surrounding areas. } \\
\text { http://www.lafayettela.gov/PublicWorks/dpt574.asp }\end{array}$ \\
\hline R\&W Farms & $\begin{array}{l}\text { Treats food wastes from Walmart and other } \\
\text { sources, including Ft. Polk. } \\
\text { See section 7.1.1 }\end{array}$ \\
\hline Oakheart Farms & Rayne LA & $\begin{array}{l}\text { Horse stable waste } \\
\text { http://www.oakheart.info/ }\end{array}$ \\
\hline $\begin{array}{l}\text { Natural Resources } \\
\text { Recovery }\end{array}$ & Baton Rouge LA & $\begin{array}{l}\text { Yard waste composting } \\
\text { http://www.naturalresourcesrecovery.com/ }\end{array}$ \\
\hline Jeffco Transportation* & Convent LA & $\underline{\text { http://www.manta.com/c/mrsz3kz/acadiana-compost }}$ \\
\hline Acadiana Compost* & Covington LA & $\underline{\text { http://www.manta.com/c/mrsf9cl/cajun-compost }}$ \\
\hline Cajun Compost* & Baton Rouge LA \\
\hline
\end{tabular}

* These installations are not verified and may no longer be in service. 


\section{Regulatory Review}

\subsection{Type III Waste Management Facilities}

Louisiana Administrative Code (LAC) 33:VII, 723 defines a Type III solid waste facility, of which there are three types:

- Facilities that dispose of construction and demolition debris or woodwaste and do not accept residential, commercial or industrial solid waste (there are $721 \mathrm{C} \& D$ landfills in LA as of 5/10/13)

- Facilities that compost organic waste to produce usable material (723 facilities)

- Facilities that separate recyclable wastes (725 facilities)

The Louisiana Department of Environmental Quality (LDEQ) is the State agency with authority over these facilities. Some of the more relevant state regulatory requirements for a Type III solid waste facility, thus composting facilities, based on current regulations as of 5/10/13 are detailed below. They include a number of general requirements, permit notifications and exceptions, the processing of yard waste/composting, other disposal units and land applications of solid waste.

An on-site installation would have to comply with best management practices to prevent contamination to surface water. The installation would also have to comply with Ft. Polk's Municipal Separate Storm Sewer Systems (MS4) permit for any discharges into storm sewers.

\subsubsection{Permitting}

Type III facilities must be permitted and the permit application must be prepared and certified by a professional engineer (PE) licensed in the State of Louisiana. Permit requirements for these facilities must be met and should be detailed in the permit. Permit application is conducted online (http://www.deq.louisiana.gov/portal/DIVISIONS/WastePermits/SolidWastePermitApplications.aspx). The authors checked with the Louisiana DEQ, and found that permit applications have a fee of $\$ 660.00$. Annual monitoring and maintenance fees are also $\$ 660.00$. There are no additional tonnage fees as compared to those charged to landfills. 


\subsubsection{Waste that can be composted (LAC 33:VII, 723)}

According to Louisiana law, the following wastes can be composted:

- Yard trash and woodwaste

- Manure

- Sewage sludge or septage

- Residential or commercial solid waste

- Any other material deemed acceptable by the LDEQ

\subsubsection{Required Documents, Reports, and Records}

As discussed in section 3.1, a permit is required. Annual reports for the period of July $1^{\text {st }}$ to June $30^{\text {th }}$ must be submitted to the Louisiana State Office of Management and Finance by August $1^{\text {st }}$ for each reporting year. Records must be maintained on-site, including the permit application, any modifications, and applicable rules and regulations. Records detailing waste applications must be maintained at the facility for a minimum of three years. After three years, records can be moved off-site, where they must be kept until the facility ceases operations. Some of the specific records that must be kept are those of waste shipments and the identification numbers of transporters that ship solid waste.

Type III facilities need to document that they have the personnel to operate their facility. The facilities also must comply with specific operation requirements, such as demonstrating that prohibited wastes are not received at the facility and that standard composting procedures, whether for commercial or residential wastes, are practiced in the composting process.

\subsubsection{Operators}

Compost operators must be certified by the Louisiana Board of Certification and Training for Solid Waste Disposal System Operators. A training course is available online at $\mathrm{http}$ ://www.lsuagcenter.com/en/communications/publications/agmag/ Archive/1999/spring/Compost+Facility+Operator+Training+Course+attracts+students+worldwide.htm. The facility must notify the Office of Environmental Services within 30 days of any changes of employment status of its operators.

\subsubsection{Required Plans for Type III facilities}

The following plans must be created, updated when necessary, and maintained on-site: 
- An operational plan that details how the facility operates

- An emergency procedures plan that would be utilized should any range of emergencies occur

- A waste segregation/recyclables plan in the event residential and/or commercial solid waste is involved

\subsubsection{Leachate \& Runoff Management for Type III Facilities}

The facility must plan on how to manage any leachate and surface runoff, and a Louisiana Point Discharge Elimination System (LPDES) permit is likely required if there is any discharge.

\subsubsection{Security Requirements for Type III Facilities}

The perimeter of the site must be fenced (or have similar access control), and entrances should be locked when no one is present.

\subsubsection{Required Type III Composting Facility Components}

The following components are identified in LAC 33:VII, 723:

- Receiving area

- Mixing area

- Curing area

- Compost storage area

- Truckwash area (designed to prevent groundwater contamination)

- Runoff collection system (permit likely required for any discharge)

- Leachate collection

- On-site/off-site treatment system

\subsection{Compost Operational Parameters and Quality}

LAC 33:VII, 723 also contains requirements for compost operational parameter and quality.

\subsubsection{Metal Concentration of Finished Compost}

Table 7 summarizes acceptable metal concentrations of finished compost in $\mathrm{mg} / \mathrm{kg}$ of dry weight. Category I is the most restrictive, generally for food production. Non-food uses may qualify for category II compost. 
Table 7. Metal concentration levels of finished compost ( $\mathrm{mg} / \mathrm{Kg}$ dry weight).

\begin{tabular}{|l|l|l|}
\hline Metal & Category I & Category II \\
\hline Arsenic & $<41$ & $41-75$ \\
\hline Cadmium & $<39$ & $39-85$ \\
\hline Copper & $<1500$ & $1500-4300$ \\
\hline Lead & $<300$ & $300-840$ \\
\hline Mercury & $<17$ & $17-57$ \\
\hline Nickel & $<420$ & 420 \\
\hline Selenium & $<100$ & 100 \\
\hline Zinc & $<2800$ & $2800-7500$ \\
\hline
\end{tabular}

\subsubsection{Pathogen Reduction}

In composting, microbial deactivation is accomplished by sustained elevated temperatures. The state of Louisiana requires that thermic processes for in-vessel, static-aerated pile, or windrow method composting must be maintained at a certain level. The solid waste is kept at minimum operating conditions of $40{ }^{\circ} \mathrm{C}$ for five days. For $4 \mathrm{~h}$ during this period, the temperature must exceed $55^{\circ} \mathrm{C}$.

If the compost will be used for food chain applications (crops, even if they are intended as food for animals; land with hunting; etc.), the compost must be processed further to reduce pathogens. The solid waste is maintained at operating conditions of $55^{\circ} \mathrm{C}$ or greater for three days. If the windrow method is used, the solid waste attains a temperature of $55^{\circ} \mathrm{C}$ or greater for at least 15 days during the composting period, and the windrow is turned at least five times during this high-temperature period.

\subsubsection{Vector Reduction Requirements (for food chain applications only)}

Vector reduction requirements are only required if the compost is to be used in a food chain application (see previous section). Two factors affect vectors (or pests): readily available food and rapid treatment by aerobic process. The state of Louisiana requires that one of the following methods are followed:

- The specific oxygen uptake rate (SOUR) for final compost treated in an aerobic process is equal to or less than 1.5 milligrams of oxygen per hour 
per gram of total solids (dry weight basis) at a temperature of $20^{\circ} \mathrm{C}$. This essentially limits the availability of readily available food for vectors.

- The final compost is treated in an aerobic process for 14 days or longer. During that time, the temperature of the composting material shall be higher than $40^{\circ} \mathrm{C}$ and the average temperature of the composting material shall be higher than $45^{\circ} \mathrm{C}$.

- The $\mathrm{pH}$ of composting material is raised to 12 or higher by alkali addition and, without the addition of more alkali, remains at 12 or higher for two hours and then at 11.5 or higher for an additional 22 hours.

- If the compost is to be applied to agricultural land, forest, or a public contract site, another alternative to achieving vector attraction reduction is to incorporate the applied final compost into the soil within six hours after application to the land, unless otherwise specified by the permitting authority.

\subsection{Best Management Practices for Composting Yard Waste, Race Track Stable Bedding, or Woody Waste, or Agricultural Production/Processing Wastes}

An alternative regulatory approach to establishing an authority to operate a compost facility is administered by the Louisiana Department of Agriculture and Forestry, and this approach entails less effort to set up and has fewer monitoring requirements (http://www.Idaf.louisiana.gov/portal/Portals/0/SWC/ Ag\%20solid\%20Waste/Ag\%20Solid\%20waste\%20BMP\%20guidelines.pdf). Provided a composting operating facility limits its materials to yard waste, race track stable bedding, woody waste, and/or agricultural production/processing wastes, this program can be used to regulate the compost operation.

Operators under this program develop a plan and submit it for review. If accepted, a letter of acceptance will be sent and this will be the basis of operation. There are no annual reporting requirements or training requirements (although training at the LSU Ag Center Compost Operator Training Program is recommended). However, if complaints occur, and they are deemed accurate, operators will be asked to correct the conditions outlined in the complaints. If the conditions are not corrected, the LDEQ solid waste division could step in to manage them (per the regulations discussed above); a loss of exempt status could ensue; and/or enforcement action may be taken. 
In the case of Ft. Polk, this would allow for management of various sources of vegetative wastes, such as yard waste, storm debris, cleared trees, etc. Although not indicated in the guidelines (link given above), food wastes can also be included, if allowed by LDEQ (confirmed by telephone meeting, see Appendix 4 for email record). However, it would not allow for the composting of food wastes mixed with paper/plastic, paper, consumer contaminated paper, compostable plastics, cardboard, wood from pallets or construction demolition lumber, or sludge. If Ft. Polk is willing to work within these limitations, then this could be an excellent way to establish the composting operation. Or, it could be an effective means to start the operation, and with additional regulatory oversight added over time. 


\section{Waste Assessment at Ft. Polk}

Ft. Polk's waste assessment capabilities were determined during a 05o8November 2012 visit. The visit provided the team with an opportunity to review key waste-generating areas. In addition, waste generation records were reviewed and compost-suitable wastes from those records were analyzed. As a means of comparison, general waste information pertinent to Army installations is also discussed below.

\subsection{General Waste Generation at Military Installations}

The USEPA has conducted national assessments of hazardous wastes in the United States. Figure 7 is a breakout of findings reported by USEPA (2005). It is probably reasonable to expect that municipal solid waste (MSW) generation at military bases is similar to this distribution, although some differences are likely (it is probably reasonable to assume, for example, that food wastes are greater at military installations due to the policy of providing food in excess to soldiers). The majority of MSW, 80\%, is in organic forms. It is also interesting to note that a significant portion of constituents, if separated, can be composted for nutrient recovery. This includes food (13.9\%), yard waste (13.4\%), and wood (6.4\%). Paper, which makes up $28.5 \%$, is generally best managed by recycling, but a significant portion is unrecyclable due to consumer contamination (see below) or fiber damage, and these portions are also amenable to composting.

Medina and Waisner (2011) conducted a study of solid and hazardous waste generation at military installations, focusing on Joint Base Lewis-McCord (JBLM) (Washington) and the Picatinny Arsenal (New Jersey). Because the study focused on all solid wastes, the findings were greatly affected by large building and demolition projects and by soil remediation projects, both of which can generate massive amounts of wastes. However, a critical issue in waste generation at Ft. Polk and other installations like it is the annual fluctuation in population. For example, Fort Lewis had a population that ranged from 25,494 in fiscal year (FY) 2003 to 51,132 in FY 2008 (the US Federal FY is from 1 October to 30 September). These population variations were related to preparing units for large deployments during Operations Enduring Freedom and Iraqi Freedom. Fort Lewis combined with McChord Air Force Base in 2010 to form JBLM. 
Figure 7. Typical composition of municipal solid waste (USEPA 2010).

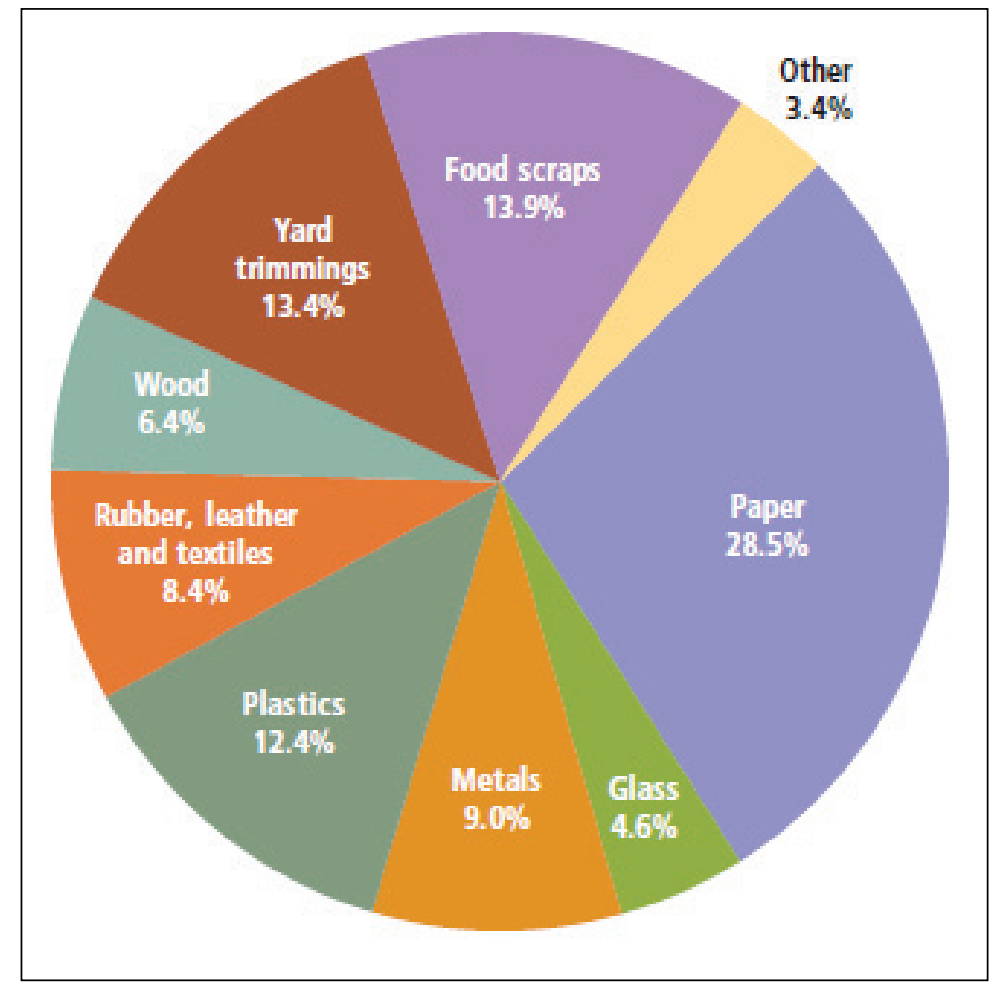

Concurrent Technologies Corporation (CTC) has conducted a series of waste audits for 6 of the 8 NZW installations. CTC prepared detailed audits for Ft. Hood and Ft. Hunter-Liggett. A draft report was reviewed and their findings indicated that most wastes produced at military installations are potentially divertible. However, the studies identified a form of wastes called Consumer Contaminated Wastes, or CCW. These are materials that are made unrecyclable by the nature of their use. They include paper towels used in handwashing, paper and plastic food wrappings and containers, soiled tissue paper, etc. These materials could make up to about 30\% of the MSW streams studied.

\subsection{Review of Waste Generation Areas at Ft. Polk}

\subsubsection{Joint Readiness Training Area (JTRC)}

The JTRC is a critical component of Ft. Polk. Mission Readiness training has been the primary focus of the JTRC over the past decade, preparing soldiers for deployed operations. And over the same period, this service has been utilized to prepare those deployed to Afghanistan. The mission in Afghanistan has included counter insurgency fighting, training of Afghan military and police, and maintaining security of friendly villages and 
towns. Very little military action has been taken against any standard military organization; rather, irregular Taliban or even local tribal organizations have been engaged. Consequently, the Mission Readiness training has been conducted taking these conditions into account. Soldiers have trained using simulated forward operating bases (FOBs) and simulated towns as preparation for operations in Afghan villages. AfghanAmericans have served in role-playing scenarios to prepare soldiers for interactions with the Afghan people. Operational units submit training requests with mission elements that they would like to focus on, and the JTRC designs missions, exercises, and scenarios to prepare the units.

There are four primary solid waste generation points from these training areas (Table 6). The first is food from the dining facilities (DFAC) at the FOB areas. Typically, soldiers will have breakfast and dinner at an FOB DFAC. Soldiers eat as much as they please. Inevitably, some food is wasted. This is collected in roll off bins, and is currently composted at the R\&W Farm (see Section 7.1.1). Used paper/plastic service items is collected in garbage and landfilled.

During training missions in the field, soldiers typically eat MREs. MREs are enclosed in thick plastic to protect the food from spoiling and from the environment. This plastic makes recovering the food and other compostable components of the MREs challenging. Unwanted MREs can be donated to charities, provided they are unopened and not deployed in the field. However, once an MRE is deployed in the field (staged in a location or parachuted in), it is considered compromised. Any unused, field-deployed MREs or MRE components from opened meals are landfilled. There has been some discussion of the use of pyrolysis as an approach that might be effective for recovering energy from MREs.

Garbage from the FOB/Village and Training areas is collected in large roll off bins. Smaller containers are provided to recover recyclable materials. However, the roll off bins are frequently used indiscriminately for any unwanted items, including Class V material (explosives, pyrotechnics, small arms ammunition, etc). As a result, the field-collected wastes are hand sorted at the Field Waste Separation facility operated by Red River under the direction of Ms. Vickie Joseph. The facility is the primary solid waste contractor at Ft. Polk, and Class V material is removed and recyclable materials are recovered. However, assessments of these operations indicated that it would be difficult to add a separation for 
compostable materials, and probably not very worthwhile in terms of the amount recovered for the effort expended. Table 7 summarizes key wastes generated from the JTRC operations and discusses the applicability of composting.

Table 7. JTRC Wastes and applicability for composting.

\begin{tabular}{|l|l|l|l|}
\hline Waste Stream & Description & Current Handling & Composting Applicability \\
\hline Food Wastes from DFAC & $100 \%$ food & $\begin{array}{l}\text { Composted at } \\
\text { R\&W Farm }\end{array}$ & Yes \\
\hline Garbage from DFAC & $\begin{array}{l}\text { Paper \& plastic service } \\
\text { items, wrappers, uneaten } \\
\text { or partially eaten food }\end{array}$ & Landfilled & $\begin{array}{l}\text { Possibly, if compostable service } \\
\text { items were used to replace } \\
\text { plastics/styrofoams or if separating } \\
\text { consumer contaminated paper }\end{array}$ \\
\hline $\begin{array}{l}\text { Camp/Village/Mission } \\
\text { Garbage }\end{array}$ & $\begin{array}{l}\text { A wide range of materials, } \\
\text { including Class V materials }\end{array}$ & $\begin{array}{l}\text { Hand sorted, then } \\
\text { landfilled }\end{array}$ & $\begin{array}{l}\text { No, the sorting process would } \\
\text { have to be greatly expanded, and } \\
\text { would not be economically viable }\end{array}$ \\
\hline MRE's & $\begin{array}{l}\text { Whole MRE units and } \\
\text { waste components from } \\
\text { opened MRE's }\end{array}$ & Landfilled & $\begin{array}{l}\text { No, wrappings are not } \\
\text { compostable. Removing would not } \\
\text { be worth it. }\end{array}$ \\
\hline
\end{tabular}

As Operation Enduring Freedom has been winding down, the JTRC has been adapting its mission to Decisive Action/Full Spectrum Operations training. This training focuses on maneuvers against adversaries organized in conventional military units. As such, this training will deemphasize FOB and village operations. In many cases, units will parachute into their training areas, or fly into the Alexandria Airport (about 50 miles east) and set up staging areas there, then maneuver to the training areas at Ft. Polk.

Decisive Action/Full Spectrum Operations will have an impact on the solid wastes derived from the JTRC. With operations originating out of the Alexandria Airport, there will be an additional waste component, and managing these remote solid wastes will probably be more complicated than current operations. In addition, without the standard FOB areas, waste generation will likely be more diffuse and result in smaller dumpsters and roll offs. Food would most likely come from MREs, with less emphasis on deployed dining hall facilities (DFACs). These changes will probably make controlling waste generation even more challenging than it is now.

\subsubsection{Dining Hall Facilities (DFACs)}

The Ft. Polk assessment included as study of two DFACs and waste analysis is presented in Table 8 . The first used china and metal silverware 
as service items. Garbage was limited to napkins, wrappers, and other small items. At the second DFAC, food was served on disposable, noncompostable paper and plastic containers with plastic silverware; however, the team was told that china and metallic silverware are generally used at this site. The hosts were not able to identify why that particular day they were using disposable service items, but they speculated that it may have resulted from a problem with the dishwashing equipment. Pre-consumer food wastes at both locations were run through a garbage disposal. However, as discussed in section 4.4, other DFACs do not have garbage disposals and landfill waste pre-consumer food. Post- consumer food and service waste is landfilled at all sites.

Table 8. DFAC wastes and applicability for composting.

\begin{tabular}{|l|l|l|l|}
\hline Waste Stream & Description & Current Handling & Composting Applicability \\
\hline Food Wastes from DFAC & $100 \%$ food & $\begin{array}{l}\text { Disposed by garbage } \\
\text { disposal or landfilled. }\end{array}$ & $\begin{array}{l}\text { Yes. Garbage disposal appears to } \\
\text { be efficient and clean, when } \\
\text { available, but some DFACs are not } \\
\text { equipped. }\end{array}$ \\
\hline Garbage from DFAC & $\begin{array}{l}\text { Wrappers, uneaten or } \\
\text { partially eaten food; } \\
\text { occasionally paper \& } \\
\text { plastic service items }\end{array}$ & $\begin{array}{l}\text { Landfilled } \\
\text { Possibly, particularly if } \\
\text { compostable service items are } \\
\text { used. However, costs are a factor. } \\
\text { Another option is to separate out } \\
\text { consumer contaminated paper. }\end{array}$ \\
\hline
\end{tabular}

The DFACs apparently maintain paper/plastic containers and plastic silverware for patrons who wish to take food to-go. These are not compostable or degradable materials. The DFAC managers reported that they had looked into these materials, but found their costs several times that of the materials currently used. However, as discussed in section 2.3 .5 , the impact per meal is on the order of $\$ 0.60$. Perhaps by adding a modest surcharge for the use of disposable items, this extra cost could be addressed.

\subsubsection{Army \& Air Force Exchanges Services (AAFES) activities}

AAFES operates Ft. Polk's post exchange (PX) and manages food concessions. The authors interviewed Beth Prichard, who directs AAFES activities at Ft. Polk, and e-mail conversations were conducted with Mark Leeper, the Chief Environmental Manager of AAFES. Table 9 summarizes the waste profile from their operations. The PX participates in Ft. Polk recycling programs for most large items, like cardboard, plastic bottles, aluminum, etc. At this time, food waste from the PX is landfilled. There 
are two types of food waste: the first is containerized food that has passed its expiration date and the second is unpackaged produce, dairy, and meat. Technically, both can be composted, but the effort to remove the food from containers adds extra costs, although food packaged in sealed paper or plastic containers could be ground and applied to the compost in that manner. The authors recommend starting with unpackaged produce, dairy, and meats.

Table 9. AAFES wastes and applicability for composting.

\begin{tabular}{|l|l|l|l|}
\hline Waste Stream & Description & Current Handling & Composting Applicability \\
\hline $\begin{array}{l}\text { Fresh Food Wastes } \\
\text { from PX }\end{array}$ & $\begin{array}{l}\text { 100\% food } \\
\text { food }\end{array}$ & $\begin{array}{l}\text { Landfilled } \\
\text { packaging }\end{array}$ & Yes \\
\hline $\begin{array}{l}\text { Garbage from food } \\
\text { vendors }\end{array}$ & $\begin{array}{l}\text { Wrappers, uneaten or } \\
\text { partially eaten food; } \\
\text { paper \& plastic service } \\
\text { items }\end{array}$ & Landfilled & $\begin{array}{l}\text { Yes, but would require food to be } \\
\text { removed from packaging; probably } \\
\text { not cost-effective }\end{array}$ \\
\hline $\begin{array}{l}\text { Possibly, particularly if compostable } \\
\text { service items are used. However, } \\
\text { costs \& policies are a factor. Another } \\
\text { option is the separation of consumer } \\
\text { contaminated paper items. }\end{array}$ \\
\hline
\end{tabular}

Food concessions at Ft. Polk include several national chains such as Burger King, Pizza Hut, and Charlie's Subs. These chains have national requirements for their wrappers, disposable service items, boxes, and other packaging. These materials do not appear to be compostable or biodegradable. Anthony's Pizza is an AAFES brand and the Pig Shack is a local vendor. AAFES can request use of compostable materials for these local vendors; however, this might bring up issues of cost and competitiveness with the national chain vendors.

\subsubsection{Mulligan's}

Mulligan's is a restaurant and pub operated by the Directorate of Family Moral, Welfare and Recreation (MWR) and is located in the golf course club house on Ft. Polk. Mr. Charlie Johnson, the Manager of Mulligan's, met with us and discussed its operation. Like the other food services evaluated, Mulligan's also disposes of food using the garbage disposal (except for large catering jobs, when food may be placed in trash) (Table 10). Mulligan's does use disposable food service items but is unique in that it has adopted biodegradable or compostable products for many of its service items (Figure 8), and is continuously searching to improve on these products. 
Table 10. Mulligan's wastes and applicability for composting.

\begin{tabular}{|l|l|l|l|}
\hline Waste Stream & Description & Current Handling & Composting Applicability \\
\hline $\begin{array}{l}\text { Food Wastes from } \\
\text { DFAC }\end{array}$ & $100 \%$ food & $\begin{array}{l}\text { Disposed by } \\
\text { garbage disposal }\end{array}$ & $\begin{array}{l}\text { Yes, but garbage disposal } \\
\text { appears efficient and clean. }\end{array}$ \\
\hline Garbage & $\begin{array}{l}\text { Wrappers, uneaten } \\
\text { or partially eaten } \\
\text { food; paper \& } \\
\text { plastic service } \\
\text { items }\end{array}$ & Landfilled & $\begin{array}{l}\text { Yes, many of the service } \\
\text { items are compostable. }\end{array}$ \\
\hline
\end{tabular}

Figure 8. Compostable service Items used by Mulligan's.

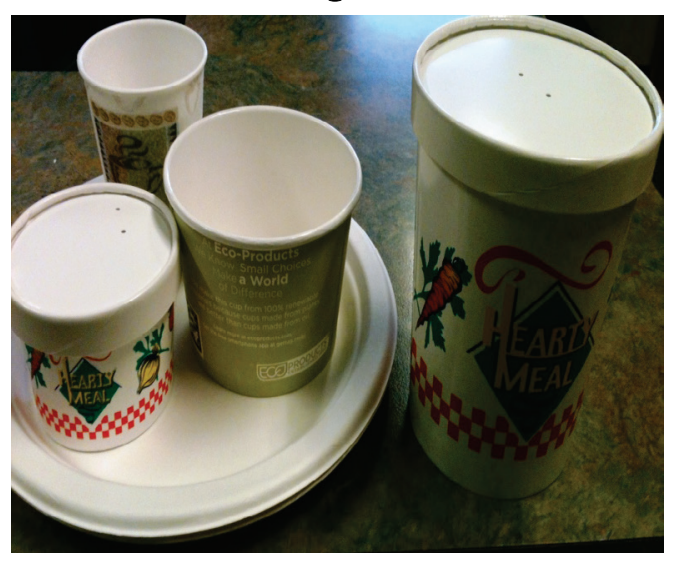

Mulligan's also provides catering services, both on and off the installation. Catering typically results in significant amounts of pre-consumer food waste. With proper coordination, this waste could conceivably be incorporated into a composting operation.

\subsubsection{DFMWR Large Events}

DFMWR hosts several large events at Ft. Polk, some of which involve thousands of people. Multiple food vendors provide service during these large events, and people can also bring their own food and drinks. These events are typically conducted on the weekends, and a massive cleanup effort is conducted to get the base prepared for business the following day. The amount of solid waste generated by these events is very large. There have been vigorous efforts to get participants to self-segregate their waste during these events by having volunteers stand by trash receptacles directing and asking people to segregate wastes, but the results have not been particularly effective. There are some events to which the public at large is invited to participate, making control more difficult, and these visitors might not value the Ft. Polk Net Zero goals. 
The large quantities of wastes generated during these events and the lack of effective segregation would make incorporating these wastes in a composting effort very difficult. Add to this the extreme time pressures to clean up the base, and it does not appear that the goal of incorporating these wastes in a composting operation is reasonable.

However, these large events can continue to be good opportunities to promote responsible waste management. Perhaps, over time, a change in attitudes could be developed by the Ft. Polk community and the surrounding areas, and this might result in better waste segregation during these large events. If that is the case, then it might be possible to revisit this waste source for composting.

\subsubsection{Department of Public Works (DPW) Roads and Grounds Maintenance}

The DPW Roads and Grounds Maintenance group removes plant material strictly for road clearance. They reported that they had removed about 20 roll offs $\left(20 \mathrm{yd}^{3}\right)$ of plant material over about a one-year period. Table 11 summarizes DPW Roads and Grounds waste generation.

Table 11. DPW ground and maintenance wastes and applicability for composting.

\begin{tabular}{|l|l|l|l|}
\hline Waste Stream & Description & Current Handling & $\begin{array}{l}\text { Composting } \\
\text { Applicability }\end{array}$ \\
\hline $\begin{array}{l}\text { Vegetative material from } \\
\text { road maintenance }\end{array}$ & $\begin{array}{l}\text { Large vegetative } \\
\text { materials }\end{array}$ & Landfilled & Yes \\
\hline
\end{tabular}

\subsubsection{Spring and Fall Cleanup}

The post supports an installation-wide spring and fall cleanup operation. This operation produces vegetative materials, similar to those from the road maintenance.

\subsubsection{Wastewater Treatment Plants}

There are currently two wastewater treatment plants (WWTPs) that serve Ft. Polk. One is located at Ft. Polk and the second is just off-site to the south of the installation. Both WWTPs are operated by American Water. The primary waste generated by the WWTPs is wet sludge (Figure 9), which is generally treated by aerobic digestion; the waste is then either dried in a drying bed or pressed. 
Figure 9. Sewage sludge in drying bed at American Water Operated Wastewater Treatment Plant.

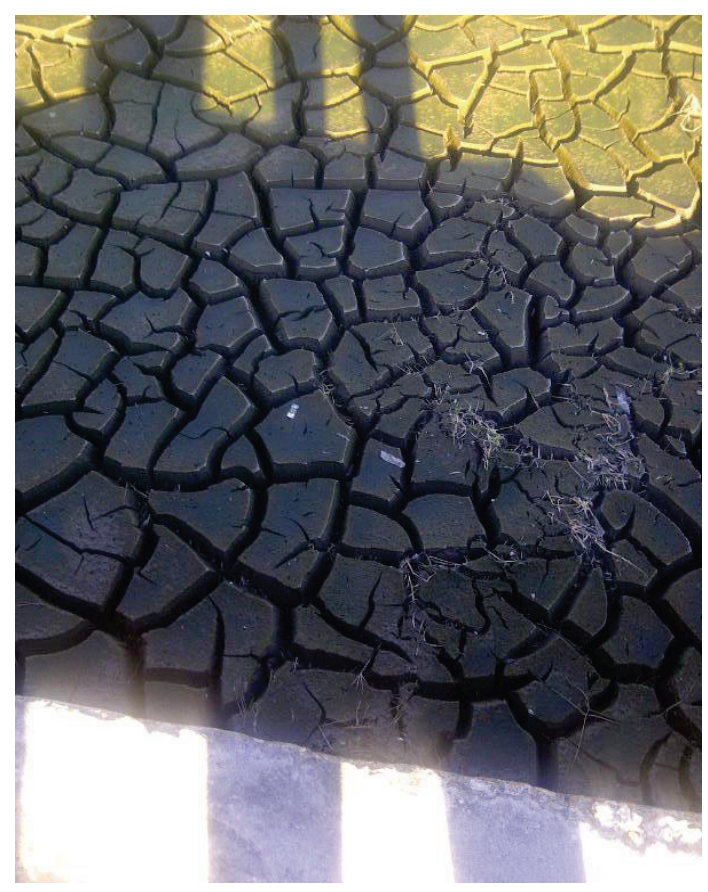

The sludge generated at the plants is currently landfilled (Table 12). However, like most WWTP sludge, it can be incorporated into a composting project. The sludge reportedly has very little metals and should be applicable for land application. ${ }^{1}$ ERDC received a sludge sample and conducted metal extraction and analyses (Table 13), and confirmed that sludge metal concentrations are low enough for soil application when incorporated into compost (Table 6). This would meet the goals as a Type 1 compost material, allowing for the broadest application.

Table 12. WWTP wastes and applicability for composting.

\begin{tabular}{|l|l|l|l|}
\hline Waste Stream & Description & Current Handling & Composting Applicability \\
\hline Sludge & $\begin{array}{l}\text { Wet sludge from } \\
\text { aerobic digesters }\end{array}$ & Landfilled & Yes \\
\hline
\end{tabular}

Table 13. Metal analysis (in $\mathrm{mg} / \mathrm{Kg}$ ) of sludge collected from one of the WWTP, operated by American Water at Ft. Polk. ND $=$ Non-detect. (Selenium was measured later, and non-detect).

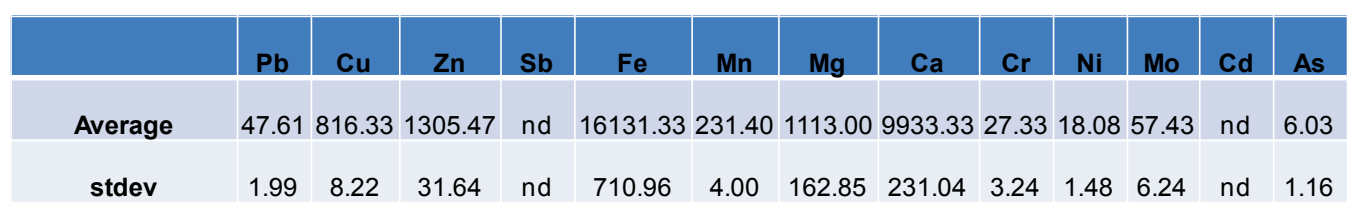

1 Dohoney, B. 2012. Personal Communication with Victor Medina, November 7. Ft. Polk, LA. 


\subsection{Specific Wastestreams}

\subsubsection{Pulverized Paper}

The Army routinely uses pulverization as a means of sensitive document destruction. Paper pulverization is a more aggressive treatment than shredding, which is commonly used in businesses, and it is believed that the residuals from pulverized paper are impossible to reconstruct. The pulverization process completely destroys the paper fibers, so the residuals are not suitable for recycling. This wastestream can be composted and, as discussed in section 2.3.4, can actually improve the quality of the compost.

\subsubsection{Damaged Wood Pallets}

Wood pallets are commonly used for shipping and receiving, and are generally reused. However, many are damaged over time. These are currently being landfilled or used as boiler fuel. Campbell et al. (1997) showed that wood residuals from lumber applications are readily compostable. ERDC received samples of the wood pallet material from Ft. Polk. There was no evidence of oily material, such as that found with creosote treatment. Analyses for metals were conducted, and most metal concentrations were below detection limits (Table 14). Of those metals detected, they were of no concern environmentally.

Table 14. Metal analyses $(\mathrm{mg} / \mathrm{Kg}$ ) of wood pallet samples from Ft. Polk. ND $=$ Non-detect.

\begin{tabular}{|c|c|c|c|c|c|c|c|c|c|c|c|c|c|c|c|}
\hline Sample ID & $\mathrm{Pb}$ & $\mathrm{Cu}$ & $\mathrm{Zn}$ & $\mathbf{S b}$ & $\mathrm{Fe}$ & $\mathrm{Mn}$ & $\mathrm{Mg}$ & Al & $\mathrm{Ca}$ & $\mathrm{Cr}$ & $\mathrm{Ni}$ & Mo & $\mathrm{Cd}$ & As & U \\
\hline WP_Bldg 2833_1 & $\mathrm{ND}$ & $\mathrm{ND}$ & 6.75 & $\mathrm{ND}$ & 40.62 & 27.02 & 95.06 & 10.16 & 782.80 & $\mathrm{ND}$ & $\mathrm{ND}$ & $\mathrm{ND}$ & ND & $\mathrm{ND}$ & $\mathrm{ND}$ \\
\hline WP_Bldg 2833_2 & ND & ND & 5.44 & ND & 41.88 & 26.46 & 94.58 & 9.76 & 707.20 & ND & $\mathrm{ND}$ & ND & ND & $\mathrm{ND}$ & ND \\
\hline WP_Bldg 2833_3 & ND & ND & 5.38 & ND & 55.12 & 25.94 & 91.62 & 17.37 & 699.20 & ND & ND & ND & ND & ND & ND \\
\hline AVG & ND & ND & 5.86 & ND & 45.87 & 26.47 & 93.75 & 12.43 & 729.73 & ND & ND & ND & ND & ND & ND \\
\hline SD & & & 0.77 & & 8.03 & 0.54 & 1.86 & 4.28 & 46.13 & & & & & & \\
\hline WP_Bldg 3622A_1 & ND & $\mathrm{ND}$ & 7.40 & ND & 19.39 & 51.84 & 187.56 & 5.49 & 609.40 & ND & ND & $\mathrm{ND}$ & ND & $\mathrm{ND}$ & $\mathrm{ND}$ \\
\hline WP_Bldg 3622A_2 & $\mathrm{ND}$ & $\mathrm{ND}$ & 9.27 & $\mathrm{ND}$ & 32.90 & 46.98 & 156.90 & 13.54 & 598.40 & $\mathrm{ND}$ & ND & $\mathrm{ND}$ & $\mathrm{ND}$ & $\mathrm{ND}$ & $\mathrm{ND}$ \\
\hline WP_BIdg 3622A_3 & ND & $\mathrm{ND}$ & 7.36 & $\mathrm{ND}$ & 21.40 & 36.86 & 129.84 & 6.17 & 463.40 & $\mathrm{ND}$ & $\mathrm{ND}$ & $\mathrm{ND}$ & ND & $\mathrm{ND}$ & $\mathrm{ND}$ \\
\hline AVG & ND & ND & 8.01 & ND & 24.56 & 45.23 & 158.10 & 8.40 & 557.07 & ND & ND & ND & ND & ND & ND \\
\hline SD & & & 1.09 & & 7.29 & 7.64 & 28.88 & 4.46 & 81.30 & & & & & & \\
\hline WP_Bldg 3622B_1 & $\mathrm{ND}$ & $\mathrm{ND}$ & $\mathrm{ND}$ & ND & 20.80 & 22.96 & 159.32 & 8.67 & 753.20 & ND & ND & $\mathrm{ND}$ & ND & $\mathrm{ND}$ & $\mathrm{ND}$ \\
\hline WP_Bldg 3622B_2 & $\mathrm{ND}$ & ND & $\mathrm{ND}$ & ND & 44.90 & 24.36 & 176.62 & 41.56 & 822.20 & ND & ND & $\mathrm{ND}$ & ND & $\mathrm{ND}$ & $\mathrm{ND}$ \\
\hline WP_Bldg 3622B_3 & ND & ND & $\mathrm{ND}$ & ND & 31.66 & 22.02 & 158.06 & 12.12 & 739.60 & ND & ND & ND & ND & ND & ND \\
\hline AVG & ND & ND & ND & ND & 32.45 & 23.11 & 164.67 & 20.79 & 771.67 & ND & ND & ND & ND & ND & ND \\
\hline SD & & & & & 12.07 & 1.18 & 10.37 & 18.07 & 44.29 & & & & & & \\
\hline WP_Bldg 4374A_1 & ND & ND & $\mathrm{ND}$ & ND & 18.30 & 29.78 & 61.74 & $\mathrm{ND}$ & 2568.00 & ND & ND & ND & ND & ND & ND \\
\hline WP_Bldg 4374A_2 & ND & ND & $\mathrm{ND}$ & ND & 14.13 & 30.20 & 59.18 & $\mathrm{ND}$ & 2510.00 & ND & ND & ND & ND & $\mathrm{ND}$ & ND \\
\hline WP_Bldg 4374A_3 & $\mathrm{ND}$ & ND & $\mathrm{ND}$ & ND & 14.22 & 30.82 & 59.56 & $\mathrm{ND}$ & 2500.00 & ND & ND & $\mathrm{ND}$ & ND & $\mathrm{ND}$ & $\mathrm{ND}$ \\
\hline AVG & $\mathrm{ND}$ & ND & $\mathrm{ND}$ & ND & 15.55 & 30.27 & 60.16 & ND & 2526.00 & ND & ND & ND & ND & ND & $\mathrm{ND}$ \\
\hline SD & & & & & 2.38 & 0.52 & 1.38 & & 36.72 & & & & & & \\
\hline WP_Bldg 4374B_1 & ND & 2446.00 & 6.47 & ND & 15.61 & 57.70 & 120.80 & 6.36 & 441.40 & ND & ND & ND & ND & $\mathrm{ND}$ & ND \\
\hline WP_Bldg 4374B_2 & $\mathrm{ND}$ & 2436.00 & 4.89 & $\mathrm{ND}$ & 11.09 & 60.26 & 134.32 & 6.86 & 449.60 & $\mathrm{ND}$ & ND & $\mathrm{ND}$ & ND & $\mathrm{ND}$ & $\mathrm{ND}$ \\
\hline WP_Bldg 4374B_3 & ND & 2730.00 & 5.83 & ND & 83.28 & 63.70 & 139.56 & $\mathrm{ND}$ & 483.80 & $\mathrm{ND}$ & ND & ND & ND & $\mathrm{ND}$ & ND \\
\hline AVG & ND & 2537.33 & 5.73 & ND & 36.66 & 60.55 & 131.56 & 6.61 & 458.27 & ND & ND & ND & ND & $\mathrm{ND}$ & ND \\
\hline SD & & 166.93 & 0.80 & & 40.44 & 3.01 & 9.68 & 0.35 & 22.49 & & & & & & \\
\hline
\end{tabular}

\subsubsection{Vegetative Debris from Hurricane Rita}

Hurricane Rita made landfall in southern Louisiana in 2005, and was one of the largest storms on record to strike the United States. It generated a 
massive amount of vegetative waste material for Ft. Polk. This was piled up at a location adjacent to the landfill, which the team subsequently observed. This pile is still very large.

Vegetative material is needed for a successful composting operation. However, large piles from Hurricane Rita could provide enough material to start a composting operation. Additionally, the composting of this material would put it to good use, as it is currently serving no constructive purpose. Although vegetative material is routinely removed for road and grounds clearance, it is likely that a composting operation will require large reservoirs of vegetative materials from future area storms.

\subsubsection{Off-Site Generated Wastes}

There are certainly sources of off-site wastes that could be integrated into a composting operation. The Boise Cascade mill in Deridder generates large quantities of paper fiber that could be incorporated into a compost formulation. The area is surrounded by farming communities that could contribute large amounts of vegetative material. Nearby Sabine Parish has numerous poultry operations which could be a great source of nutrients for a composting operation.

Incorporating these and other off-site wastes is a risky proposition, as it would probably require Ft. Polk to accept any liability associated with these materials. However, an off-site composting operation could address a range of wastes from a number of sources (see discussion in section 7.1).

\subsection{Analysis of Waste Generation Records}

The Department of Defense (DoD) maintains a centralized solid waste reporting system that provides readily available information that can be analyzed for each installation - SWARWeb (Solid Waste Annual Reporting Web system). ERDC downloaded SWARWeb data from Ft. Polk from 1999 to 2012 (Table 15). This data indicates that landfilled MSW ranged from over 13,000 tons to 6,500 tons, and averaged 9,675 tons annually. Some data is spotty, such as sewage sludge, which totaled 125 tons in 1999 and 261 tons in 2003, but does not show up in the system for other years. That is because sewage sludge is generally managed by the wastewater treatment contractor, American Water, and does not show up on Ft. Polk's waste tracking most of the time. The analysis indicates that there are several sources of vegetative material that could be used for a composting 


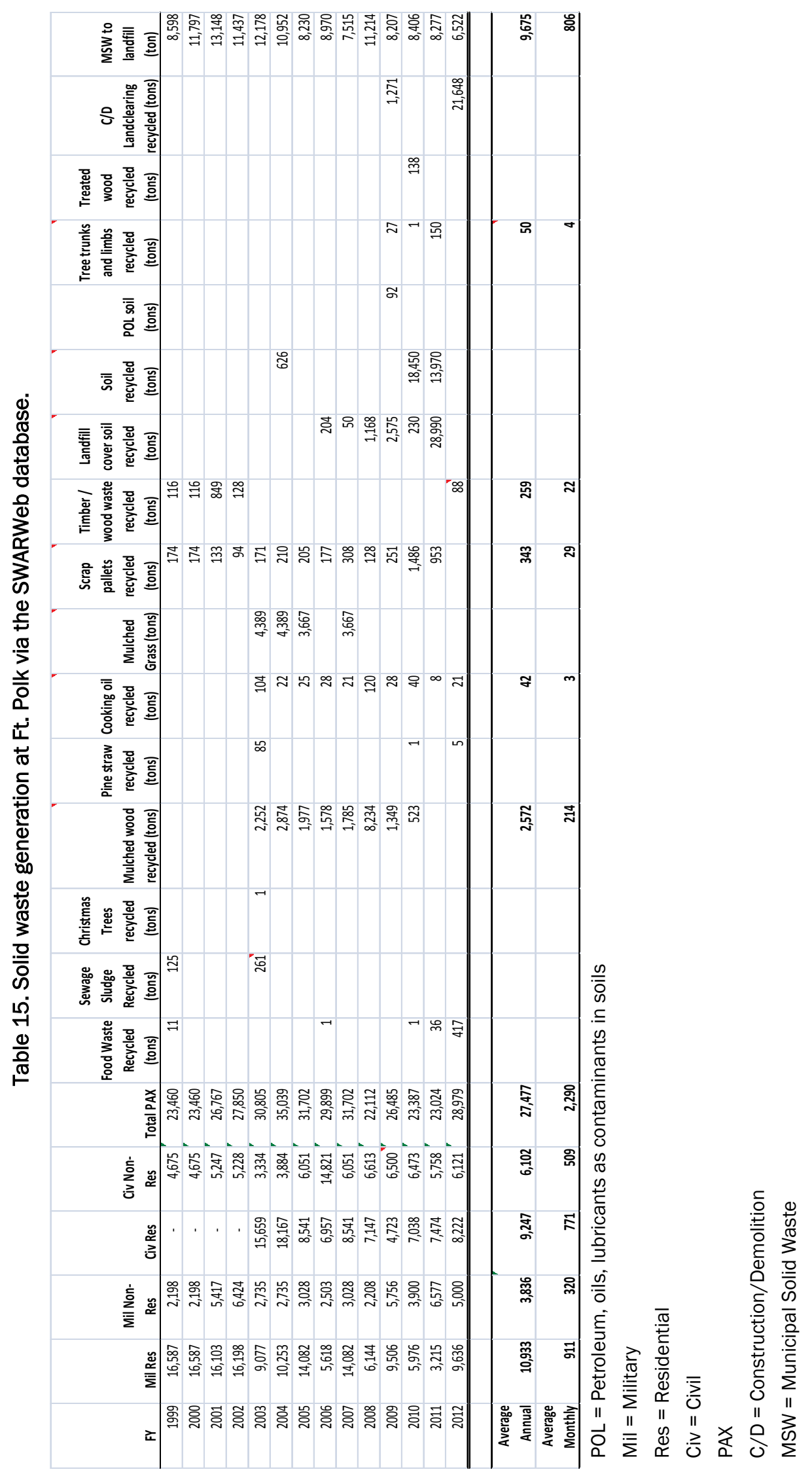


operation; on average, approaching 3000 tons. However, the data also shows great variability in the production of vegetative wastes. For example, in the fiscal year (FY: the Federal FY is from 1 October to 30 September) 2008, there was over 8000 tons of mulched wood generated compared to only 500 tons in FY 2010. Several years have no mulched wood reported, which either means that the mulching operation was suspended that year, or that the vegetative material was reported elsewhere.

Ft. Polk provided ERDC detailed information on solid waste disposal at Ft. Polk for a period between July 2011 and August 2012 (Table 16). Looking at a one-year period (from July 2011 to June 2012), the total wastes generated was 4852 tons. Three sources of food wastes were the food at the FOBs, pre-consumer food from North Fort DFACs and food from the main post. Added all together, this food resulted in a total of 1815 tons over the one year period from July 2011 to June 2012, which represents $37 \%$ of the landfilled MSW. Therefore, composting just these food wastes could represent a very significant solid waste diversion.

Table 16. Detailed solid waste generation data for Ft. Polk from July 2011 to August 2012.

\begin{tabular}{|c|c|c|c|c|c|c|c|c|c|}
\hline Month & $\begin{array}{c}\text { Cantonment } \\
\text { MSW to } \\
\text { landfill (ton) }\end{array}$ & $\begin{array}{c}\text { pallets for } \\
\text { boiler fuel } \\
\text { (ton) }\end{array}$ & $\begin{array}{l}\text { Field waste } \\
\text { collected } \\
\text { from FOBs } \\
\text { (ton) }\end{array}$ & $\begin{array}{l}\text { Compacted } \\
\text { residual } \\
\text { from RRSC } \\
\text { sorting } \\
\text { operation } \\
\text { (ton) } \\
\end{array}$ & $\begin{array}{c}\text { Recyclables } \\
\text { recovered } \\
\text { by RRSC } \\
\text { sorting } \\
\text { (ton) } \\
\end{array}$ & $\begin{array}{c}\text { Pre- } \\
\text { consumer } \\
\text { food waste } \\
\text { from North } \\
\text { Fort DFACs } \\
\text { (ton) }\end{array}$ & $\begin{array}{l}\text { Contaminated } \\
\text { soils (JP8) to } \\
\text { landfill (ton) }\end{array}$ & $\begin{array}{c}\text { Food from } \\
\text { main post } \\
\text { (ton) }\end{array}$ & MREs (ton) \\
\hline $\mathrm{Jul} / 2011$ & 274 & & 65 & & & & 8 & 0 & \\
\hline Aug/2011 & 451 & & 100 & & & & 27 & 36 & \\
\hline Sep/2011 & 334 & & 38 & & & & 12 & 1 & \\
\hline Oct/2011 & 361 & & 0 & & & 129 & 12 & 5 & \\
\hline Nov/2011 & 428 & 99 & 143 & 132 & 11 & 69 & 15 & 61 & \\
\hline Dec/2011 & 322 & 59 & 11 & 10 & 1 & & 0 & 0 & \\
\hline $\operatorname{Jan} / 2012$ & 442 & 60 & 67 & 61 & 6 & 60 & 0 & 50 & \\
\hline Feb/2012 & 486 & 86 & 48 & 43 & 5 & 27 & 58 & 16 & \\
\hline Mar/2012 & 472 & 91 & 179 & 102 & 77 & 58 & 41 & 51 & \\
\hline Apr/2012 & 479 & 78 & 67 & 80 & & 42 & 37 & 18 & \\
\hline May/2012 & 455 & 118 & 137 & 121 & 16 & 63 & 7 & 67 & 0.46 \\
\hline Jun/2012 & 348 & 96 & 143 & 142 & 1 & 30 & & 34 & \\
\hline Jul/2012 & 389 & 94 & 132 & 116 & 16 & 70 & & 50 & \\
\hline Aug/2012 & 446 & 62 & 81 & 81 & 0 & & & 44 & \\
\hline Monthly avg & $406^{\prime}$ & 84 & 87 & 89 & 15 & 61 & 20 & 31 & \\
\hline One year total & & & & & & & & & \\
\hline $\mathrm{Jul} / 2011$ to Jun/2012 & $4852^{\prime}$ & 687 & $998^{\prime \prime}$ & 691 & $117^{\top}$ & 478 & $217^{\prime}$ & 339 & 0.46 \\
\hline
\end{tabular}




\subsection{Summary of Waste Assessment}

Table 17 summarizes a composting strategy that could be used for Ft. Polk. Vegetation and food are the most readily available compostable materials. If we assume a 50:50 mix of food and vegetation by mass (based on Rynk and Sailus 1992), we find that food is the limiting element at 23 tons per week, so a total of 46 tons per week of food and vegetation can be composted. This would equate to a diversion of about 186 tons per month or 2208 tons per year. Since the average total waste generation at Ft. Polk is on the order of 9000 tons per year, this is about a $25 \%$ diversion. However, since total landfilled wastes appear to be decreasing, this diversion may be substantially higher. Furthermore, alternative composting strategies could be considered to increase the diversion, including the use of less food per vegetation, use of sewage sludge, and the addition of other wastes over time, such as paper, cardboard (from pizza boxes), etc.

Table 17. Diversion estimated from a 50:50 food waste, vegetation composting strategy.

\begin{tabular}{|c|c|c|}
\hline Item & Note & Monthly average (ton) \\
\hline Pallets & from RRSC data & 84 \\
\hline Food waste, North Fort DFAC & RRSC & 61 \\
\hline Food waste, Main & RRSC & 31 \\
\hline \multirow[t]{2}{*}{ landclearing, CD wood } & SWAR & 167 \\
\hline & Monthly & Weekly total \\
\hline Food total & 92 & 23 \\
\hline Wood total & 251 & 63 \\
\hline \multicolumn{3}{|c|}{$\begin{array}{l}\text { Plan on } 50 \text { - } 50 \text { mix of food and wood } \\
\text { therefore, we're limited by availability of "easy" food }\end{array}$} \\
\hline 23 & \multicolumn{2}{|l|}{ ton/week food } \\
\hline 23 & \multicolumn{2}{|l|}{ ton/week wood } \\
\hline 46 & \multicolumn{2}{|c|}{ ton/week "easy" compostables } \\
\hline 184 & \multicolumn{2}{|l|}{ ton/month } \\
\hline 2208 & \multicolumn{2}{|l|}{ ton/year } \\
\hline
\end{tabular}

In terms of compost produced, it is important to consider that partial degradation in composting can result in significant mass losses over time (Tiquia et al. 2002). If we assume a 30 to $40 \%$ mass loss, the amount of compost produced would vary from 1324 to 1546 tons per year. 


\section{Potential Compost Use at Ft. Polk}

\subsection{Background}

The Army owns almost five million hectares (ha) of land in the United States - including 73 installations with greater than 4,000 ha each - that routinely require rehabilitation and maintenance to support training activities (DOD 2001). These lands are often highly eroded and incur significant losses of topsoil, organic matter, and nutrients, and are prone to invasion by exotic plant species, leading to further ecological degradation. Consequently, the Army is required by law to control water and air pollution, maintain ecosystem sustainability, protect native biological diversity, and control the spread of exotic species on its training lands. As such, the Army could derive significant benefits from utilization of its own organic, composted wastes to aid in management of its training lands.

The benefits of applying compost to soils that are very sandy, lack organic matter, have poor water holding capacity, and/or are highly eroded or compacted are well known. Application rates as low as 10-15 tons per acre (about 0.25 inches thick) have been shown to significantly increase organic matter content in sandy soils (Torbert et al. 2007; Zhang et al. 1997), with the benefits often carrying over into subsequent years following one initial application (Mamo et al. 1998; Watts et al. 2012a; Watts et al. 2012b). Any increase in organic matter content improves water holding capacity and the moisture release dynamics of soils (Turner et al. 1994; Giusquiani et al. 1995), consequently supporting more desirable plant communities (Watts et al. 2012a). Military maneuver training frequently results in heavily compacted soils, and compost applications nearly always decrease bulk density (Turner et al. 1994; Giusquiani et al. 1995; Pagliai and VittoriAntisari 1993), thereby minimizing erosion risk and improving water infiltration, porosity, and storage for plant use as the growing season progresses (Zhang et al. 1997).

In highly disturbed areas, such as bivouac sites, drop zones, and maneuver areas, the soil usually lacks sufficient organic matter to support the necessary vegetative cover required to control erosion. This is frequently one of the main reasons for using composts or other organic materials on training lands. Disturbed military training and testing lands are almost always reseeded with perennial native vegetation, mostly warm season grass 
species (big bluestem (Andropogon gerardii Vitman), indiangrass (Sorghastrum nutans (L.) Nash), switchgrass (Panicum virgatum L.), little bluestem (Schizachyrium scoparium L.), and Virginia wildrye (Elymus virginicus L.)). These species are used abundantly in reclamation as they develop extensive root systems that penetrate deep into soils, providing a very effective safeguard against erosion (Drake 1983). Over the long term, this vegetation is most effective at mitigating erosion and providing suitable wildlife habitat, but is difficult to establish in the short term because these species are slow growing and susceptible to competition with weedy plant species (Paschke et al. 2000; Wilson and Gerry 1995; McLendon and Redente 1992). Because native perennial vegetation is adapted to nutrient poor soils, oversupplying nutrients in the form of purchased fertilizers is detrimental to them and often results in failure (Launchbaugh et al. 1962; Jung et al. 1988; Wilson and Gerry 1995; Skeel and Gibson 1996; Warnes and Newell 1998; Levy et al. 1999; Brejda 2000). Adequate soil restoration often requires significant quantities of organic matter, but locating suitable sources is difficult and expensive. Further, many sources are unsuitable, as they have high $\mathrm{N}$ concentrations that encourage weed growth. Therefore, the carbon:nitrogen $(\mathrm{C}: \mathrm{N})$ ratio of the material is important in determining suitability. Poultry litter, biosolids, and manures have C:N ratios less than 30 , which results in an oversupply of $\mathrm{N}$ that encourages weed growth, making them less desirable for rehabilitating damaged training areas. Other organic matter sources with higher C:N ratios, such as wood wastes (Morgan 1994; Zink and Allen 1998; Reever Morghan and Seastedt 1999; Alpert and Maron 2000; Blumenthal et al. 2003), compost derived from landscape and wood wastes (Mamo et al. 1998; Busby et al. 2007), processed municipal solid waste (Busby et al. 2006; Busby et al. 2007; Torbert et al. 2007), and sucrose (McLendon and Redente 1992; Morgan 1994; Reever, Morghan, and Seastedt 1999; Paschke et al. 2000; Blumenthal et al. 2003) can immobilize enough $\mathrm{N}$ following land application to allow native vegetation to dominate reseeded sites.

\subsection{Application Rates and Techniques}

Rehabilitating degraded military training and testing sites, where soils typically lack organic matter and favorable physical and chemical properties conducive to establishing and supporting perennial plant communities, requires significant inputs of organic amendments to improve the probability for success and sustainable future use. Minimum compost application rates should be in the range of 10 to 15 tons per acre, which translates to a layer about 0.25 inches deep over the entire acre 
(McConnell et al. 1993). A review of rates used in experimental studies suggest that applications of finished compost between 10 and 30 tons per acre provide observable improvements in soil physical and chemical properties without significant phytotoxic effects (McConnell et al. 1993). Application rates for sandy soils can be doubled without significant concern for negative impacts (McConnell et al. 1993; Busby et al. 2006; Watts et al. 2012a, b). Application rates beyond 80 to 100 tons per acre should be split and should always be planned based on soil and compost nutrient and heavy metal analyses to ensure application of compost at those rates is safe. Studies by Watts et al. (2012a) and Mamo et al. (1998) have indicated that the benefits of a single heavy application rate can still be observed five years after the initial application.

Since most compost applications on degraded training ranges and maneuver areas are usually followed by some type of revegetation effort, it is important to ensure the compost is evenly applied and subsequently incorporated before seeding perennial grass species. This is most effectively accomplished with a commercial manure spreader; however, dump trucks or front-end loaders can also be utilized. Using the 0.25 inch compost depth as a guide equivalent to a rate of $10-15$ tons per acre, the spreading equipment should be calibrated to achieve the desired application rate, recognizing that some variability in rate across the area to be treated is perfectly acceptable. After the compost has been spread, it should be incorporated into the soil using a disk plow, if possible, to a depth of 4-6 inches. This provides the best possible seedbed for subsequently seeding grasses and minimizes the probability that the compost will be removed from the site via wind or water erosion.

\subsection{Department of Public Works (DPW) Roads and Grounds}

DPW Roads and Grounds are responsible for maintaining vegetation near roads for erosion control. They conduct fertilizer application projects for this purpose. However, erosion control is the only reason they conduct any revegetation. Though DPW Roads and Grounds is a potential user for this compost, the group would probably have rather limited needs.

\subsection{Integrated Training Area Management (ITAM)}

Integrated Training Area Management (ITAM) maintains the lands used for training. Dr. Kittie Stanger, Chief of ITAM, was interviewed for this report and indicated that erosion is a great concern for ITAM management. 
Increasing the vegetation in an area - as well as the organic matter of soil can help mitigate erosion. Currently, ITAM applies Lime and Triple 16 fertilizer to about 45 to 50 acres annually. Compost can serve to minimize the use of fertilizers and lime. If we apply 10 tons per acre, as discussed in section 5.2, it would result in a use of 450 to 500 tons annually, which would be about $1 / 3$ the estimated production given in section 4.5. However, much higher application rates are feasible (80 to 100 tons per acre), and the ITAM actually manages significantly more land (1700 to 1900 acres) than what is routinely fertilized. Dr. Stanger has indicated that she believes that ITAM could use as much as compost as can be generated. ITAM is also investigating the use of paper mill fiber by-products from the local Boise Cascade Paper Mill in Deridder, LA as a soil amendment (see section 7.1.3).

\subsection{Directorate of Family, Morale, Welfare, and Recreation}

This group maintains baseball and multipurpose sports fields ( 15 total), parade grounds, and a 200-acre golf course. They indicated they could use compost to maintain soil moisture and provide fertilization. Focusing on the golf course alone (assuming 10 tons per acre per year) provides a total potential annual usage of 2000 tons per year; this is about $90 \%$ of the total compost production discussed in section 4.4 . 


\section{Potential for On-Site Composting at Ft. Polk}

\subsection{Location}

A suitable location for an on-base composting facility has been identified. It is adjacent to the closed landfill just west of Chaffee Rd (Figures 10 and 11). The site was previously used as a landfarm for treating sewage sludge. Its location, somewhat isolated from Ft. Polk and next to the landfill, means that the land probably does not have many options for constructive use. The site is terraced and appears to have some erosion and runoff control already in place. It is roughly square, about $350 \mathrm{~m}$ long by $100 \mathrm{~m}$ wide. It is vegetated with well-maintained grass. A thick bank of trees blocks its view from Chaffee Road and a well-maintained dirt road provides access. This site will have minimal issues with odors, noise, etc.

\subsection{General Layout and buildings needed for composting}

Figure 12 is a sketched, proposed layout for the project's solid waste composting yard. It will be fenced and include staging areas for composting feedstocks. Areas will be set up for size reduction of large vegetation and other compostables and mixing operations. The layout is best suited for a forced air static pile operation, which will allow for piles to be set up under an angled roof with open walls for easy access. A finished composting storage area will be provided as well.

ERDC estimated the costs of building a composting operation that could manage about seven weeks of waste materials, basing construction costs on an up-to-date R.S. Means spreadsheet (Appendix 3). The base price was calculated to be approximately $\$ 1.5$ million. With contingencies (20 and $50 \%$ ), a price range of $\$ 2.13$ to $\$ 2.66$ million was estimated.

\subsection{Equipment Required for Composting}

Table 18 outlines equipment typically used in most composting operations (Rynk and Sailus 1992). Prices for equipment vary substantially and are determined by the throughput each piece of machinery can handle. The Ft. Polk facility will be small to medium in size, with cost estimates based on operations that fall within this range. The team estimated a total cost of 
approximately $\$ 250 \mathrm{~K}$. Utilizing used or reconditioned equipment could reduce costs. It may also be possible to use existing equipment to meet some processing needs.

Figure 10. Aerial view of the proposed Chaffee Rd composting area.

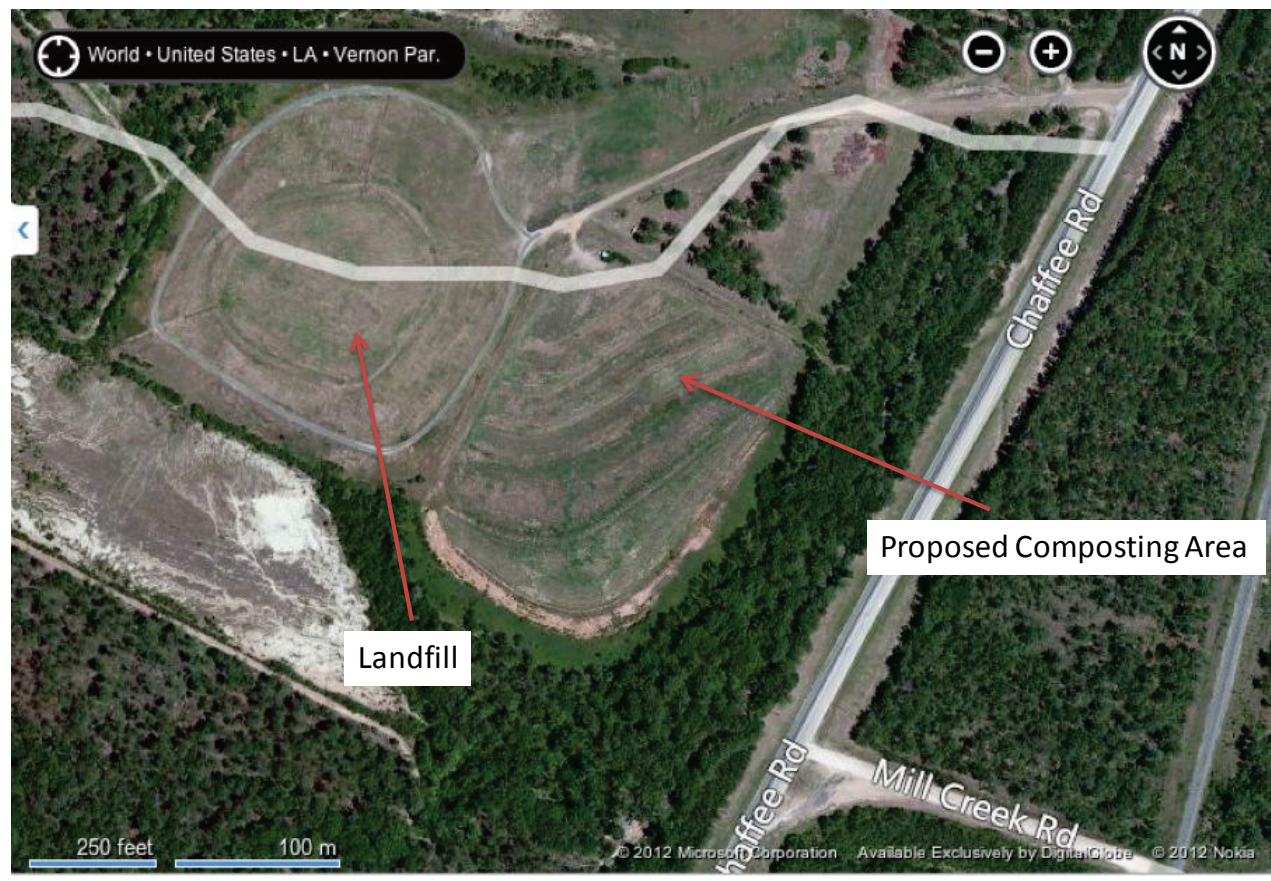

Figure 11. View of the proposed composting site looking southeast toward Chaffee Rd.

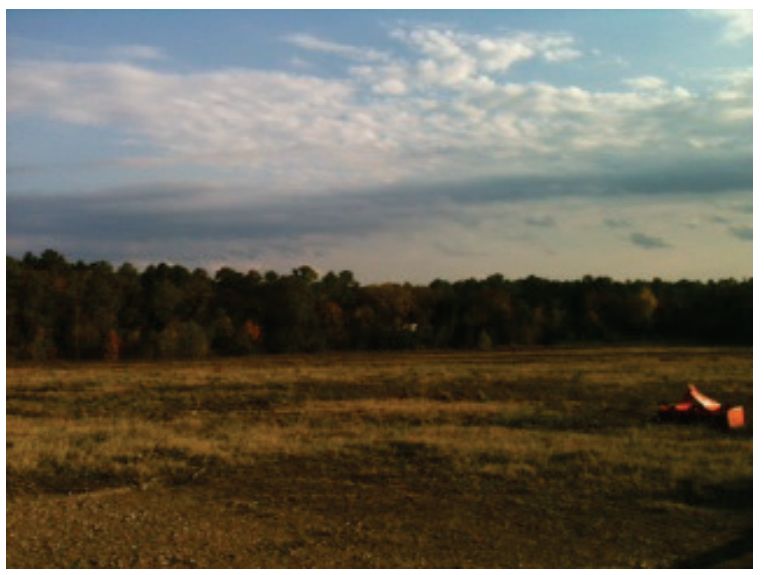


Figure 12. Idealized layout of a composting operation (courtesy of Sam Hunter, CERL).

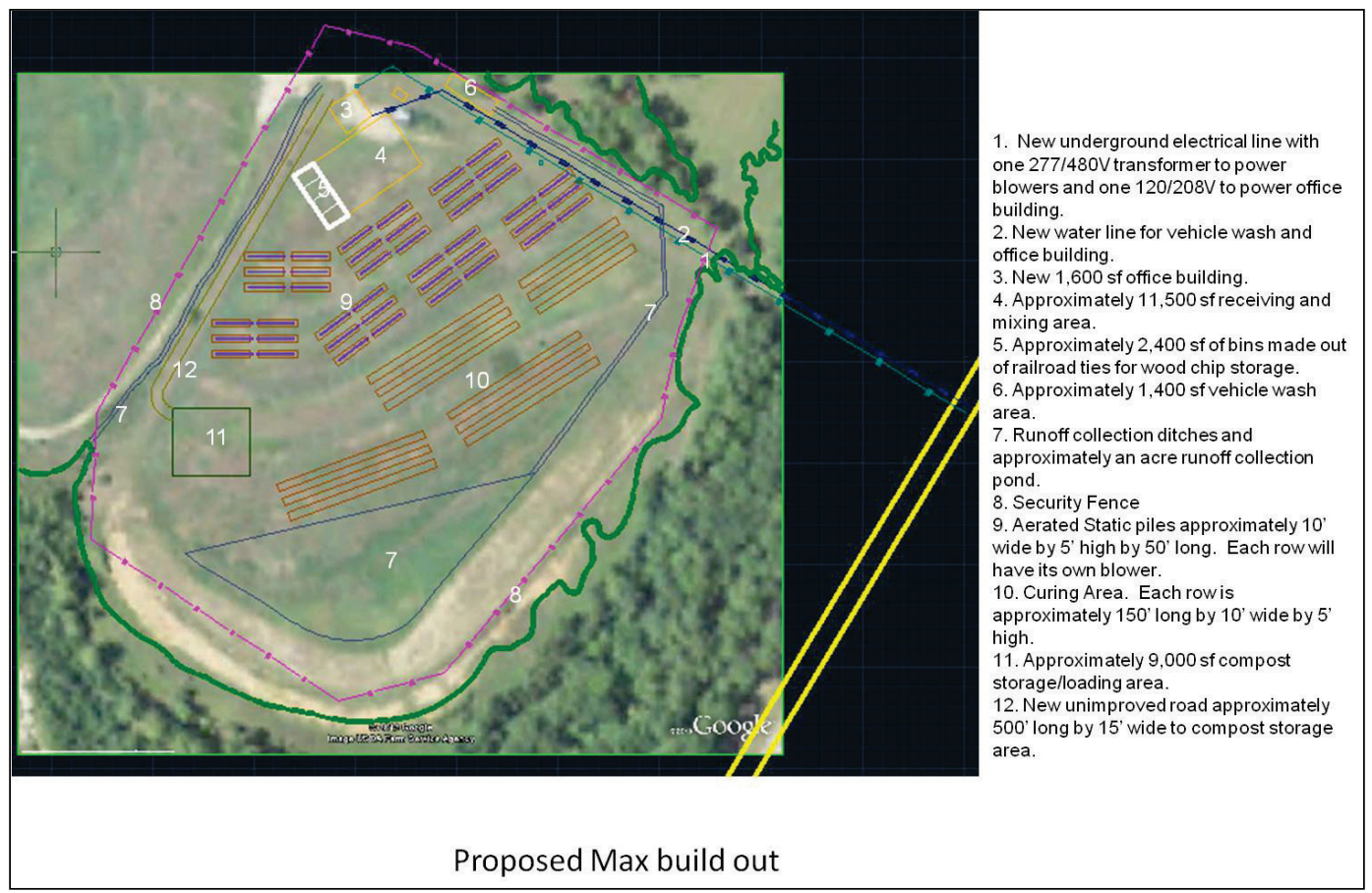

Table 18. Equipment typically required for a forced air composting operation.

\begin{tabular}{|c|c|c|c|c|}
\hline Equipment & Cost Range & Estimated Cost & Source & Comments \\
\hline Front Loader & $\$ 3$ to $10 \mathrm{~K}$ & $\$ 7 \mathrm{~K}$ & Estimated & \\
\hline Blower(s) & $\begin{array}{l}\$ 500 \text { ea. } \\
\$ 3000 \text { total }\end{array}$ & $\$ 3 K$ & Estimated & $\begin{array}{l}\text { For Forced Air. Assume } 5+1 \\
\text { backup }\end{array}$ \\
\hline Piping & $\$ 1500$ & $\$ 1.5 \mathrm{~K}$ & Estimated & $\begin{array}{l}\text { For Forced Air Static Piles. } \\
\text { Assume } 5 \times 50 \mathrm{ft} \text { piles. }\end{array}$ \\
\hline Paper shredder & $\begin{array}{l}\$ 15 K \text { to } \\
\$ 200 K\end{array}$ & $\$ 50 \mathrm{~K}$ & $\begin{array}{l}\text { Rynk and Sailus } \\
\text { 1992, } 20 \% \text { inflation }\end{array}$ & $\begin{array}{l}\text { For the incorporation of } \\
\text { consumer contaminated } \\
\text { paper/cardboard }\end{array}$ \\
\hline Wood chipper & $\$ 7 \mathrm{~K}$ to $\$ 300 \mathrm{~K}$ & $\$ 20 K$ & $\begin{array}{l}\text { Rynk and Sailus } \\
\text { 1992, 20\% inflation }\end{array}$ & \\
\hline $\begin{array}{l}\text { Compost mixers } \\
\text { (Pug Mills) }\end{array}$ & $\begin{array}{l}\$ 15 \mathrm{~K} \text { to } \\
>\$ 500 \mathrm{~K}\end{array}$ & $\$ 85 \mathrm{~K}$ & $\begin{array}{l}\text { Rynk and Sailus } \\
\text { 1992, 20\% inflation }\end{array}$ & \\
\hline $\begin{array}{l}\text { Compost Screening } \\
\text { Equipment }\end{array}$ & & $\$ 85 \mathrm{~K}$ & $\begin{array}{l}\text { Rynk and Sailus } \\
\text { 1992, 20\% inflation }\end{array}$ & \\
\hline $\begin{array}{l}\text { Total (see } \\
\text { discussion in text) }\end{array}$ & & $\$ 251.5 \mathrm{~K}$ & & \\
\hline
\end{tabular}

\subsection{Recommendations for a Ft. Polk Composting Operation}

The purpose of this study is to provide Ft. Polk with an analysis of the feasibility of establishing an on-site compost operation. The decision to 
implement an on-site composting operation or not is one that must be made by Ft. Polk management and command. ERDC nonetheless provides some recommendations in this section that could be used a guide if the decision is made to move forward.

\subsubsection{Staged start-up}

Operating a compost facility requires experience. Certain wastes can be challenging to incorporate, particularly food and sludge. Ft. Polk should consider a staged approach to beginning a compost start-up. Initially, the composting operation can focus on vegetative material. The start-up operation is relatively straight forward, has few storage or staging issues and minimal odor concerns. Vegetative materials tend to be carbon-rich materials, which can result in a slower composting process. But the need for extensive biotransformation is reduced, because the vegetative materials have virtually no offensive aspects in terms of odor, pathogenic organisms, or attraction of vectors. The vegetative approach will give the operator(s) an opportunity to develop skills in moving the compostable feed stocks and setting up the compost operation without the pressure of dealing with putrescent materials.

As time goes on, more challenging materials can be added: food, sludge, pulverized paper, and consumer-contaminated paper. These materials will add nutrients and sorptive materials, resulting in better quality compost. The expansion will make the composting operation more significant in its impact on Ft. Polk's waste management. It is recommended that food residuals be incorporated at 10 to $20 \%$ by volume initially, then expanded to up to $50 \%$ if the process is successful (USCC 2009). It may be the case that not all the food can be accepted into the composting operation.

\subsubsection{Vegetation/Bulking Agents}

Bulking agents are generally needed in composting to provide structure that allows good air flow through the compost pile. Woody vegetation generally fills this need. As discussed in section 4.4, there is substantial vegetative waste produced at Ft. Polk, but it can vary considerably from year to year. Fortunately, woody material tends to be amenable to long term staging, so this material can be saved when generated and used over long periods of time. Other bulking materials could also be considered, including damaged pallets and used pizza boxes. 


\subsubsection{Food/Sludge}

Currently, food wastes from DFACs and from most AAFES vendors are thrown out in garbage disposals where they are incorporated in wastewater and eventually treated in one of two wastewater treatment plants. However, there are two other options for the handling of food waste: one option is to collect and compost food waste on-site. One of the arguments for this option is that there is high nutritional value in the food that can be exploited in the compost operation. JBLM adopted this approach in implementing their composting operation, and report good results. ${ }^{1}$ The second option is for Ft. Polk to expand its garbage disposal of food. The garbage disposal system is already in place, is easy for DFACs, and eliminates the issues that often arise with the storage of putrefying food. Dr. Charles Stagg has reported that changing the existing solid waste contract to accommodate the inclusion of this waste is probably not feasible. Therefore, the second option is the recommended option for Ft. Polk.

Once in the WWTP, the food is combined with the sludge already in the system. There the organic matter in both the food and the sludge is partially digested. This system reduces odor-causing agents and the sludge can be more easily stored, staged, and incorporated into the composting operation compared to untreated raw food waste.

Neither the North Fort DFAC nor the DFACs serving the FOB training areas have food grinders. The North Fort DFAC food is currently landfilled, and food from the FOB training areas is collected and sent to R\&W Farms. Waste food from these sources totals nearly 100 tons per month (section 4.4). This food could be directly applied to an on-site composting operation. Another issue is that food grinders can break, which apparently happens frequently; it can take up to 150 days to replace them. Contingency plans can be developed to collect this food and deliver it to the compost operation.

\subsubsection{Paper}

The composting operation at Ft. Polk should include non-recyclable paper, particularly pulverized paper, which is a major source of waste on the base. This material is easily included in a compost recipe, potentially adding

\footnotetext{
${ }^{1}$ Norton, C. R. 2013. Personal Communication with Victor Medina. April 15. JBLM Versar, Inc. Fort Lewis, WA.
} 
beneficial qualities to the compost mix, including the ability to retain water and - with the additional organic material - improvements to soil structure. Paper waste will combine well with sludge because it will help balance the carbon nitrogen ratio and is also useful for absorbing odors.

In time, other non-recyclable paper feedstocks will be considered. These will include consumer-contaminated paper products from the DFAC and AAFES vendors. These products would require separation and most likely need to be reduced in size. The latter can be achieved through grinding or even pulverizing. With these preparations, these materials could also be effectively included in the composting operation, increasing the waste diversion significantly.

\subsubsection{Contingency Situations}

Ted Hammerschimdt (Ft. Polk, Environmental Division) reports that breakdown of garbage disposals is common, and that it can take 90 to 150 days for repairs to be completed. During this time, the food wastes are generally landfilled. A contingency could be developed that would allow for this food waste to be captured and placed into the composting operation.

In a similar manner, dishwashing equipment does break down from time to time, necessitating the use of disposable service items. With proper planning, compostable materials can be made available and the wastes diverted to a composting operation.

\subsubsection{Contaminated Soils}

Tables 15 and 16 (section 4.4) indicate that petroleum-contaminated soils are routinely generated at Ft. Polk. Interestingly, composting has been demonstrated to be a very effective means of degrading petroleum and petroleum products in soils (Jorgensen et al. 2000; Van Gestel et al. 2003). Could composting be used to treat these soils? Although evaluating this possibility is outside the scope of this project, it might be something that could be considered over time if an on-site composting operation is adopted. A strategy would involve a laboratory study followed by small pilot demonstrations in the composting facility. Any application at the compost facility should be conducted with close consultation with the LDEQ. The regulatory constraints could ultimately be the determining factor to as whether this approach could be adopted. 


\section{Other Options}

\subsection{Outside the Fence Partnership Possibilities}

The focus of this project has been on the development of an on-site operation. However, there appears to be viable, off-site possibilities. These are outlined below.

\subsubsection{R\&W Farm}

R\&W Farm is located about 20 miles from Ft. Polk (Figure 13). Currently, the farm accepts food waste from Ft. Polk, and then composts it through its windrow composting operations. In addition, R\&W Farm accepts food wastes from Walmart department stores in the state of Louisiana and possibly other sources as well. The amounts of food wastes from Ft. Polk are a relatively small part of their operation.

Figure 13. Composting operations at R\&W Farm.
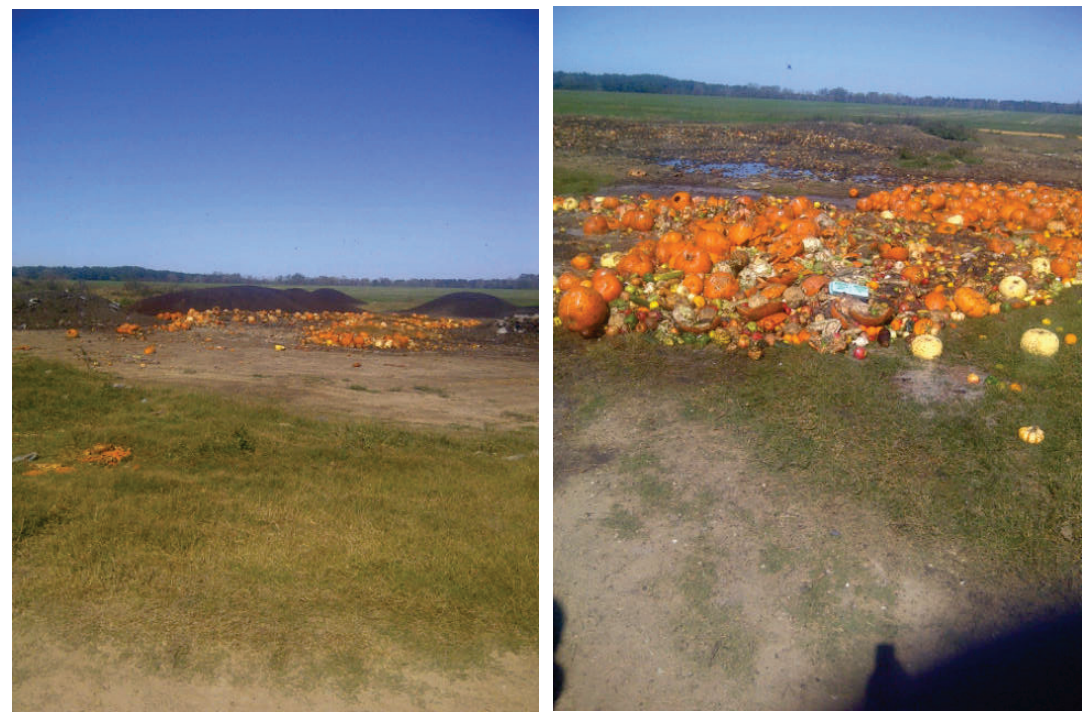

The windrows at the farm are primarily a combination of food and soil. Because there is no significant structural component in the compost, the operation has the potential to generate significant odors. During the team's visit, odors were not especially strong, but there have been reports from some Ft. Polk DPW employees of very offensive odors coming from the operation. 
However, the farm is relatively isolated, so odors may not be of great concern. The farm's owner uses the compost beneficially, as a soil amendment for growing silage for the farm's animal feeding operation. The farmer reported that the compost has had a positive effect on his crop production.

The authors' interview of the owner indicated that the operation could accept more waste - particularly food waste - from Ft. Polk. The advantage to this solution is that the farm is already available and in place and it utilizes some of the most problematic materials found at Ft. Polk: food waste. However, this farm currently only accepts food waste, and it is not clear if it would be willing to expand to take in other materials, like paper or sludges. Another disadvantage is that the compost would not be available for use at Ft. Polk.

\subsubsection{Partnerships with Local Communities}

Ms. Lorna Hanes is the Ft. Polk Community planner and she has been very active in studying waste management issues in the Ft. Polk region, particularly at the Parish level. In an interview, she indicated that the Vernon Parish has interest in jointly developing a composting program with Ft. Polk. She also indicated that there is land available for a site, and there are customers interested in compost. Vernon Parish has already developed a recycling area; thus, there is demonstrated interest in more advanced waste management processes.

Artemis Advantage, LLC, a local environmental consulting and services firm, shared information they developed in an effort to encourage interest in a regional composting center (Appendix 5). The firm had discussions with leadership from the cities of Leesville and Deridder, Beauregard Parish, and a local citizen's group. The Mayor of the City of Deridder indicated that an area near the DeRidder airport could be a good site for a regional composting center. Artermis Advantage also interviewed the Leesville Mayor, who was supportive of a center.

\subsubsection{Boise-Cascade Paper}

Artermis Advantage, LLC, interviewed the Environmental Manager at the Boise-Cascade papermill in DeRidder. They are interested in composting as a solution to the 45 tons of paper fiber by-product generated per day. This material appears suitable for land application. 
Ted Hammerschmidt of the Ft. Polk Environmental Division also shared information about recent discussions with the City of Deridder to open a regional composting operation, which would also include by-products from the Boise Cascade plant in Deridder. The concept is encouraging, but it is clear that it is still in a nascent stage.

\subsection{Some Alternative Diversions to Implementing Composting}

\subsubsection{Continued Management Practices}

One option is to continue with the current system of waste management, a system that focuses largely on landfilling, but includes some composting (at R\&W Farms) and recycling. This continuing current practice avoids costs and risks associated with starting a composting operation. However, without composting, or a similar alternative, achieving NZW is not feasible. The Army has identified NZW as a worthwhile strategic goal, and making progress towards this requires meaningful changes. Composting appears to be the most viable and cost-effective means of providing a diversion for vegetative materials, food, sludges, and most unrecyclable paper.

\subsubsection{Direct application of Vegetative Material, Paper and Sludges as Soil Amendments}

Although composting can beneficially prepare organic materials in the waste as a soil amendment, several of the key feedstocks proposed at Ft. Polk could be reused or recycled without composting. Vegetative material can be chipped and used directly as a soil amendment (Brandon et al. 2011). Pulverized paper also can be disked or plowed into soil and has many beneficial properties. Sludges can be dried and directly applied to soil as well.

However, preparing these materials for direct soil application takes significant effort, similar to the preparations needed for composting. Vegetative material must be reduced by chipping prior to application. Sludges should be dried. If consumer contaminated paper is to be used, then it will have to be shredded or pulverized. Like composting, these materials need to be staged and stored. Thus, the effort to directly apply these materials as soil amendments is comparable to composting itself.

Composting offers four significant advantages over simply applying these materials to soil directly. First, although these materials could be land 
applied directly, composting improves their suitability as a soil amendment, because the partial degradation that occurs in composting makes nutrients much more available. Second, the partial degradation occurring in composting is effective at removing odor-causing agents, such as those that might be found in the sewage sludge or in consumer contaminated paper. Third, composting provides disinfection, which would be valuable in the cases of sewage sludge and consumer-contaminated paper. And finally, composting could incorporate the food waste not suitable for direct land application.

Woody debris can also be ground and used as feedstock in a local paper mill. This approach was used to manage woody debris recovered in southern Louisiana after Hurricane Katrina (Brandon et al. 2011). BoiseCascade operates a papermill in Deridder Parish, and could be a consumer of this material.

\subsubsection{Alternatives for Food Wastes and Sludges}

Food waste and sludges are among the most challenging wastes to address. As discussed above, sludges can be directly applied as a soil amendment. This option is not practical for food, however, due to odors and concerns with vectors. However, there are two other options for these wastes that should be considered. Anaerobic digestion (AD) is a process in which wastes are converted using anaerobic processes. These are typically conducted in a closed vessel reactor. Like composting, the offensive characteristics of the waste material are usually consumed in the digestion process. Though slower than aerobic processes (like composting), anaerobic digestion can result in a more completely degraded digestate. The biggest advantage of the $\mathrm{AD}$ process is that methane is typically generated, and this can be used as a fuel. However, odor-causing gases, such as sulfides and mercaptains, are also produced and must be controlled.

ERDC has investigated the application of $\mathrm{AD}$ for food wastes at FOBs and the results are promising. The gas production is relatively high and of good quality. However, mass production of gas may require the treatment of very large waste streams. Other studies also confirm that $\mathrm{AD}$ can be applied very effectively to food, but requires that the food be separated from other wastes, which would include paper and plastic service items, for example (Garcia-Pena et al. 2011, Bernstad and la Cour Jansen. 2012). Composting would not require as much separation as $\mathrm{AD}$. 
Vermiculture is another option for foodwaste and sludges. This involves using worms to reduce the food (Garg et al. 2006, NBARD 2007) by digesting and decomposing the organic material in the food waste. Worms are very efficient organisms and their casts make excellent fertilizers. The worms themselves can be used in pet foods or as fishing bait. Vermiculture is widely used overseas, but is not common in the United States. That said, the prison at Fort Leavenworth reportedly operates a vermiculture for their food wastes. Overall, composting appears to be easier to apply and manage than vermiculture in this case. ${ }^{1}$

\subsubsection{Conclusion}

Overall, composting appears to be the best approach to deal with a wide range of problematic wastes at Ft. Polk. Although some alternatives exist, none appear as well developed and as readily implementable as composting.

\footnotetext{
1 Fey, C. A., Personal Communication with Victor Medina. US Army Environmental Command, San Antonio, TX.
} 


\section{Laboratory Study}

A small laboratory study was conducted to evaluate composting of wastes similar to those found at Ft. Polk.

\subsection{Purpose}

The purpose of the laboratory study is to evaluate the effectiveness of using composting systems like those at Ft. Polk. Specific wastes evaluated include vegetative material, food wastes, sludge (from the Ft. Polk wastewater treatment plant).

\subsection{Approach}

\subsubsection{Materials \& Recipe}

The study involved compost treatment of leaves, woody material, pine straw, sewage sludge (obtained from American Water) and food (Figure 14). The team also conducted treatments with pulverized paper and compostable products currently used by Mulligan's and provided by Ft. Polk.

Figure 14. Materials used in study (from top left to right: Leaves, pine straw, sewage sludge, \& food scraps).
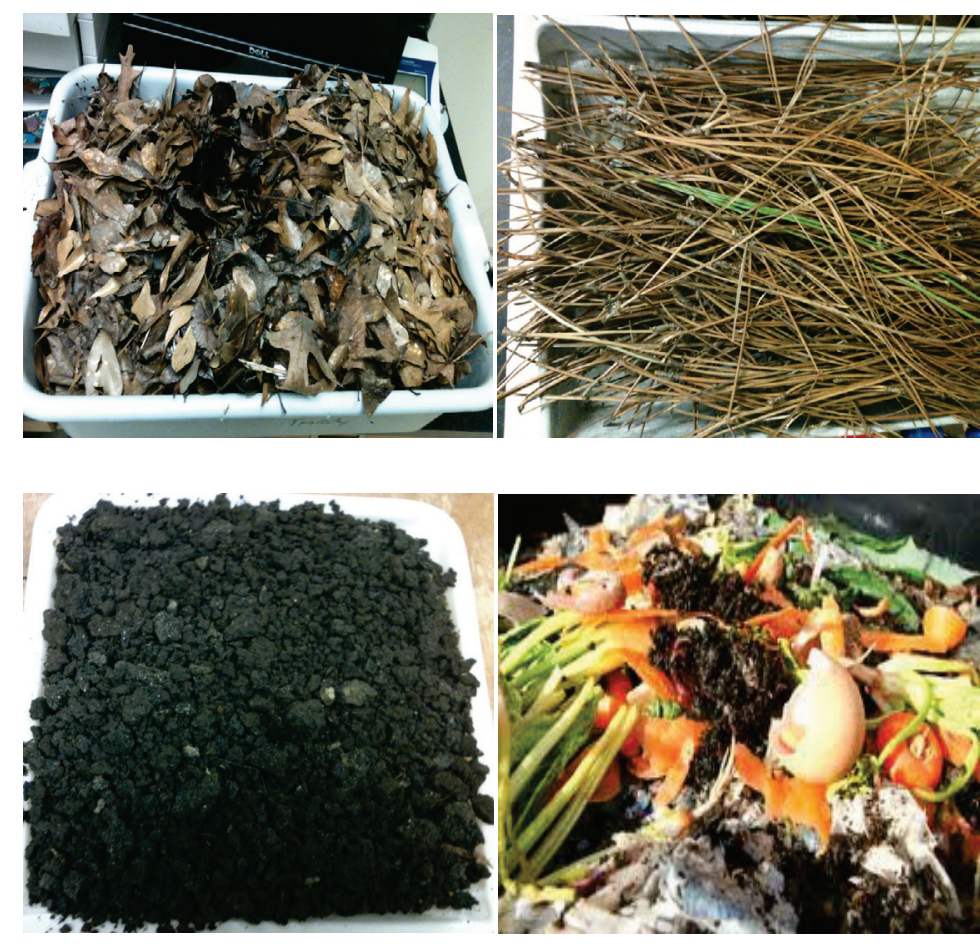
Moisture contents of key constituents were determined using a Denver Instruments moisture analyzer (Figure 15). Carbon was measured using a Total Organic Carbon (TOC) analyzer. Nitrogen was extracted first by finely grinding the materials of interest, then by using a 10:1 liquid solids ratio for extraction, and measured using Inductively Coupled Argon (ICAP) Spectrophotometry. Table 19 summarizes results of moisture, carbon, and nitrogen measurements.

Figure 15. Denver Instruments moisture analyzer.

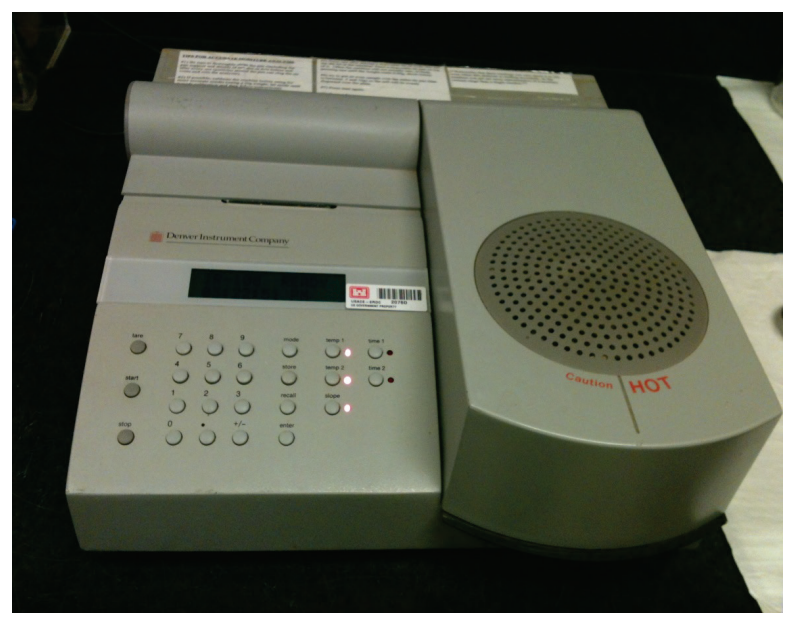

Table 19. Initial measurements and recipe used for the compost preparation.

\begin{tabular}{|c|c|c|c|c|c|}
\hline & $\%$ MC & $\begin{array}{c}\text { mass } \\
(\mathbf{k g})\end{array}$ & $\begin{array}{c}\text { Carbon } \\
(\%)\end{array}$ & $\begin{array}{c}\text { Nitrogen } \\
(\%)\end{array}$ & $\begin{array}{c}\text { C:N } \\
\text { ratio }\end{array}$ \\
\hline leaves & 12.00 & 0.100 & 48.6 & 0.9 & 54 \\
\hline straw & 4.96 & 0.100 & 56 & 0.7 & 80 \\
\hline chips & 48.6 & 1.000 & 50 & 0.1 & 500 \\
\hline food & 69 & 0.900 & 46.4 & 2.9 & 16 \\
\hline sludge & 18.55 & 1.000 & 33.6 & 5.6 & 6 \\
\hline
\end{tabular}

Compost recipes were determined using approaches outlined in Rynk and Sailus (1992). The team found that moisture content was the most critical factor in preparing the compost recipe. Table 19 also contains the masses of constituents used for the recipe. 


\subsubsection{Reactor Setup \& Incubation}

After some experimentation, the team found a large bin to be a very effective reactor (Figure 16). It allowed easy access for mixing and good aeration, eliminating the need for forced air. To maintain the high $50^{\circ} \mathrm{C}$ temperatures necessary for composting, the reactors were placed in large incubators (Figure 17). The reactor was incubated for 50 days, and were mixed and had moisture adjustments weekly.

Figure 16. Plastic bin containers used as a compost reactor.

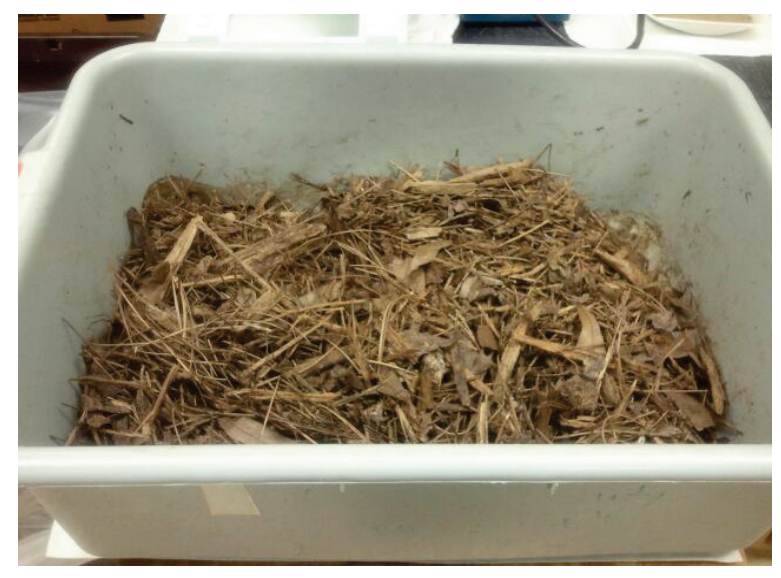

Figure 17. Incubators used in study.
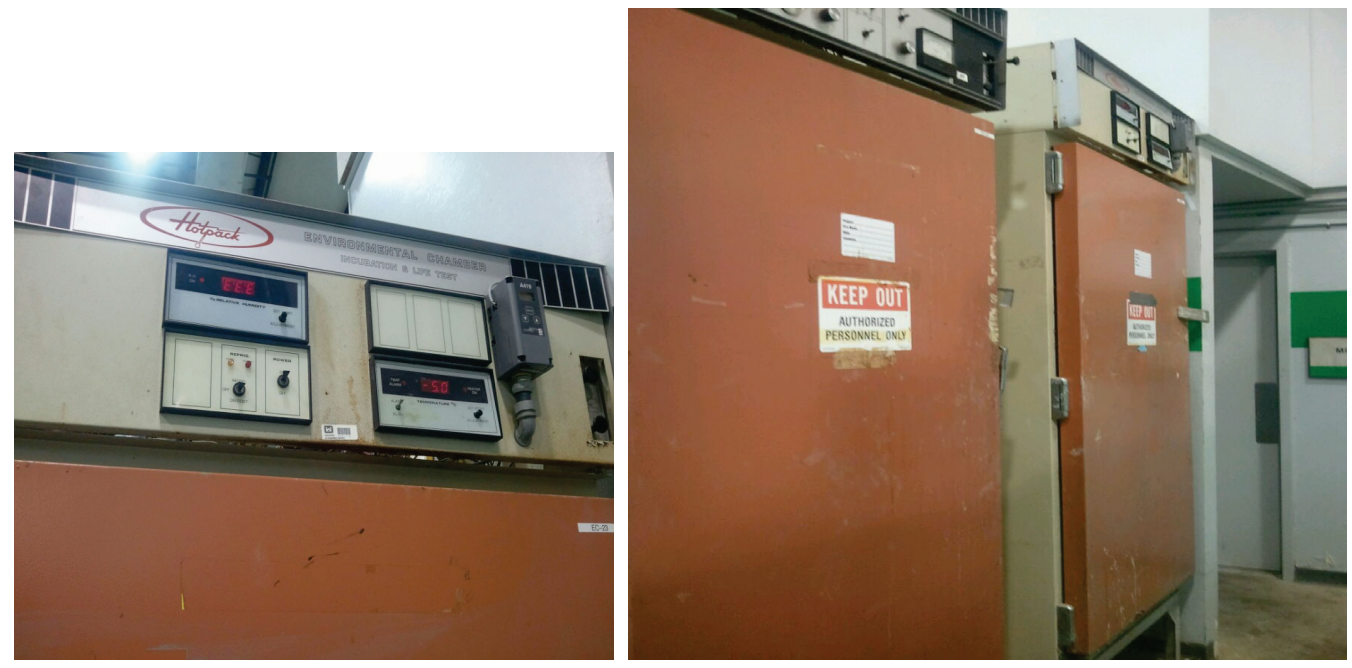

\subsubsection{Results}

Figure 18 compares initial and finished compost (after 50 days) consisting of leaves, pine straw, sewage sludge, and food. The food and sludge components were clearly visible in the initial compost preparation. Such a material would be considered unpleasant from an aesthetic standpoint. 
Figure 18. Comparison of initial (left) and finished compost (right) consisting of leaves, pine straw, leaves, sludge and food. Food is clearly visible in the initial compost (left), but almost completely degraded so as to be unrecognizable in the finished compost (right).
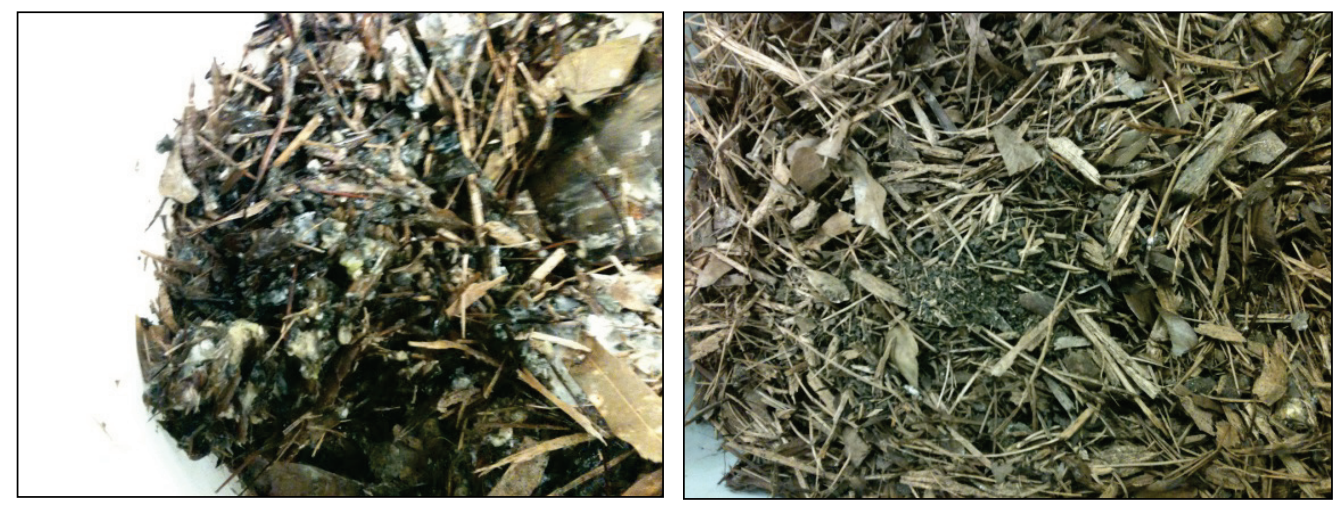

However, after 28 days of composting, it is not possible to even see the remnants of the food or sludge, and the compost has a rich appearance. No odor was evident.

Organic matter was measured using combustion at $550^{\circ} \mathrm{C}$ and $\mathrm{pH}$ was measured by extraction using a 10:1 liquids:solids ratio. Table 20 compares organic matter contents and $\mathrm{pH}$ of initial versus finished compost (50 days); once again, the compost consisted of pine straw, leaves, sewage sludge, and food. The composting process resulted in about a 30\% drop in organic matter content, indicating a consumption of readily biodegradable constituents. The $\mathrm{pH}$ was similar for both initial and finished samples.

Table 20. Volatile organic matter content and $\mathrm{pH}$ of compost reactors consisting of leaves, pine straw, sludge and food.

\begin{tabular}{|l|l|l|}
\hline & Initial (Day 0) & Finished (Day 50) \\
\hline Volatile Organic Matter (\%) & 91.86 & 61.81 \\
\hline $\mathrm{pH}$ & 6.22 & 6.45 \\
\hline
\end{tabular}

Figure 19 shows finished compost (after 50 days incubation) with pulverized paper and with shredded compostable materials obtained from Ft. Polk (see Figure 7). Both the paper and the compostable products show signs of weathering and decomposition, but both materials also maintain their identity to the naked eye. Composts made with these materials could be disked into soil or applied in areas where there is not a need to maintain aesthetic values, but composts of this type would probably not be suitable for surface application in highly visible areas. 
Figure 19. Finished (50 days) compost with pulverized paper (left) and with compostable products (right).
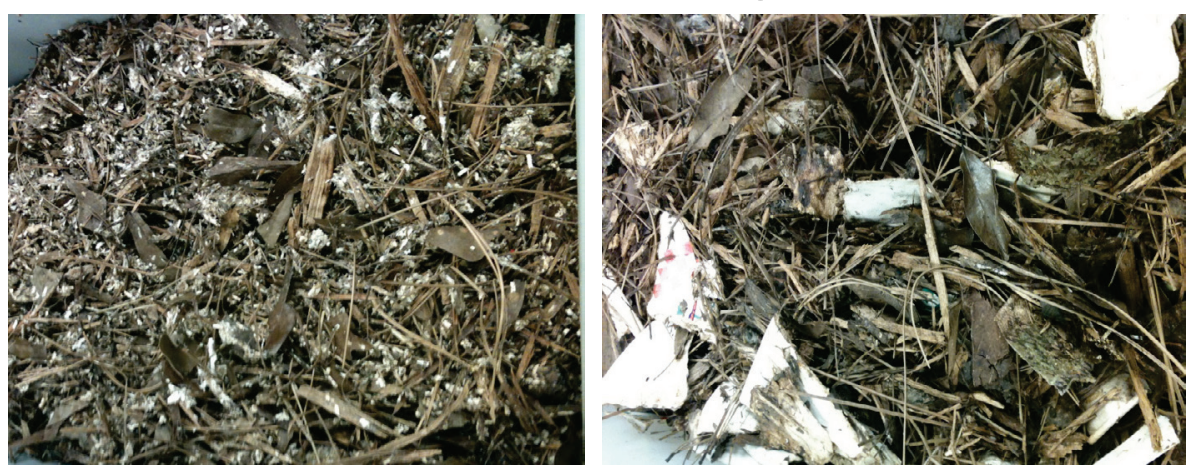

\subsection{Summary}

The small laboratory study indicates that composting very effectively incorporates food and sludge into a good quality compost material. The 50-day treatment period is reasonable for full-scale applications. Paper and compostable service items still maintained their appearance, and compost with these constituents would be best applied to remote areas where appearance would be unimportant (such as training ranges) or in disking application where the compost is integrated with the soil. The recipes used for this study could be a good starting point for actual fullscale application recipes. 


\section{Discussion}

\subsection{Implications to Other Army and DoD Installations and Army Net Zero Waste}

This assessment indicates that a properly managed, on-site composting operation at Ft. Polk is sustainable. Composting these wastes would represent a sizeable diversion for the installation. Additionally, there appears to be sufficient uses for the compost on the base. The Ft. Polk composting facility could have applications for many of the army bases located in the United States.

Because each Army installation serves a specific mission, each has its own guidelines. Thus, the waste generated at each base can be different. Taking that into consideration, there are bases that share similar waste profiles. Paper waste, for example, is found throughout the DoD, and is a major waste stream, as is food waste and consumer-contaminated paper from DFACs and AAFES.

Installation location is an important factor in what is available for composting and how viable a composting operation will be. Ft. Polk is located in a wet, temperate area in the southern US that supports lush vegetation. Storms in the area create periodic reservoirs of large vegetative debris that can be readily used in composting operations. However, installations located in the desert like Ft. Bliss (near El Paso, TX) and Ft. Irwin (near Barstow, CA), or those located in sub-arctic environments, where vegetation is sparse, may make composting untenable.

On-site use of compost also can be an issue. Selling the compost off-site, or even giving the compost away, is complicated because of regulations designed to keep the DoD from competing with private enterprise. In the case of Ft. Polk, there are extensive training lands that must be maintained and soils in the area are generally poor, and prone to erosion. Maintaining the golf course and the athletic and drill fields are also important. These could all benefit from Ft. Polk's on-site production of compost. Most comparatively sized installations would have similar uses for compost.

Location is key to a successful composting operation. Ft. Polk's Chaffee Road site is large and isolated, allowing for a wide range of composting 
options. Though most military installations are large, space can still be an issue. Space issues can be addressed by limiting the materials for composting (removing food and sludge can also greatly reduce odor issues) and/or by using static pile or in-vessel systems. In both cases, less space would be required.

Base population matters. As discussed above, Ft. Polk has an average population of about 23,000, which makes it a medium to small Army installation. However, smaller installations exist. Installations that are smaller than Ft. Polk must seriously consider whether an on-site composting operation makes sense and is cost-effective. Larger installations, on the other hand, would likely achieve many benefits from composting. In summary, on-site composting is a viable waste management approach for Ft. Polk. It may also be applicable to other military installations, although several aforementioned factors must be taken into consideration.

Off-site partnerships may make a lot of sense. By partnering with surrounding communities and businesses, a larger pool of compostable wastes can be treated and the beneficial impact from an overall perspective can be greater. By conducting composting offsite, liabilities to the base could be reduced and issues like runoff and odor could be moved off-site. Such an arrangement would probably require the installation to purchase the compost for its own use, but it would be likely that a favorable price could be negotiated.

Landfilling costs in the United States are still relatively low, making the effort and the capital costs expended for composting operations difficult to recover when considering the investment from a pure cost analysis (Renkow and Rubin 1998). However, landfilling is not consistent with achieving NZW. Furthermore, composting is a process with many benefits. It provides a diversion for many wastes that are difficult to manage otherwise, and the compost is a product that can be used to improve soil quality, promote vegetation growth, and reduce erosion. Since the compost can be beneficially used on station, cost recovery may not be as critical.

\subsection{Implications to Forward Operating Bases}

Members of the Directorate of Environmental Integration (Mr. Ed Lefler), personnel from the Engineering School (Mr. James Rowan), and current and retired Army officers (COL Courtney Paul and retired LTC Robert Tucker, Ph.D.) suggested that experiences in Kosovo, Iraq, and Afghanistan 
demonstrate that the Army needs better waste management approaches for their FOBs. These sentiments were also shared by LTC Damon Brown and SFC James Sartain, who served as science and technology advisors to the JTRC. Lessons learned from the composting conducted in Kosovo (from Dr. Tucker) can be applied in future operations. However, as of now, there is no official guidance on composting.

It is instructive to study the FOB areas at JTRC since they are representative of actual FOBs in theater. Though the JTRC FOB areas are managed differently (waste here would be taken to a central composting facility as opposed to being composted on-site), studying them could provide valuable insights about composting operations. Many types of waste from the JTRC area are amenable to composting, particularly food and garbage from the DFAC operations. While these waste materials are particularly troublesome to manage in FOB environments, they can be effectively treated through composting. The odor and pathogenicity of the waste can be controlled. Composting currently appears to be a promising concept for managing these wastes on an FOB.

There are, however, three critical issues. The first issue is the availability of woody vegetation, which is needed for composting as a structural agent to ensure good airflow. This material is not always common waste at FOB sites. In some cases, an FOB site might require removal of heavy vegetation, which could be stockpiled. But in other cases, particularly in desert or subarctic environments, vegetation might not be readily available.

It might be possible to obtain vegetative materials from the local populace, and/or logging and agricultural operations. This could be conducive for fostering friendly relations with the general community; however, it could also open avenues for hostile penetration of the FOB. Another possibility would be to use substitutes, like lumber and cardboard, from pallets and packing materials.

Another key issue is space. FOBs are generally small and do not have a lot of available space. Highly efficient, in-vessel systems could be useful in these environments, particularly systems with continuous flow operations, limiting the need for stockpiling (NDCEE 2013a, 2013b).

Space could also be addressed by having the composting operations situated off-site. This concept fits well with the full spectrum doctrine that 
fosters building positive relations and providing business development opportunities. In this case, the Army can team with other organizations like USAID and the Department of State to provide training to interested parties. This opens the base to potential hostile penetration, although perhaps no more than already is occurring with current waste management approaches.

The final issue involves use of the compost. There are some uses for compost at FOBs (for erosion control or as a filter material for odors), but certainly not enough to consume the amount of compost expected to be generated. Therefore, this compost could be offered to the local populace, presumably for agricultural activities.

A common theme runs through this discussion. Composting at FOBs requires cooperation with the local populace. This could provide a means for establishing friendly relations with them, and promoting business development for a self-sustaining society. Composting of FOB and other wastes in the area can provide enough local fertilizer to reduce the need for chemical fertilizers (unfortunately, chemical fertilizers are also used to make improvised explosive devises). If sufficient relations with a friendly local populace can be established, then composting will prove a useful means of treating food, blackwater, sludge, and other wastes at an FOB.

Composting could be used to treat contaminated soils at contingency bases. As discussed in section 6.4.5., petroleum-contaminated soils have been treated using composting. This type of contamination is also common in contingency. Other contaminants that may be found at a contingency base include explosives. Explosives have also been treated using composting, although the approach frequently involves creating anaerobic zones within the compost pile (Preston et al. 1997, Preston et al. 1998)

In-vessel reactors could be a good approach for FOBs. As discussed in section 2.4.3, a forced air, in-vessel reactor was tested at JBMHH, and the results were considered to be very positive. An in-vessel reactor would reduce space and odor concerns, which can certainly be a factor in an FOB environment. However, windrow composting can be performed with simple earthmoving equipment, which would forgo the costs of a reactor and the shipping and set up. 
The JTRC can play a critical role in evaluating and developing the concept of composting for contingency bases. Pilot demonstrations can be conducted to evaluate composting as part of training exercises. Soldiers who have been "killed" as part of an exercise can be used to conduct this activity. Another exercise could be conducted in which actors portraying the native populace are recruited to run a composting operation. If the Ft. Polk on-site compost operation is in place at the time, then personnel could participate to train the local populace actors in the composting. Other scenarios can also be developed.

\subsection{Costs and Breakeven Calculation}

In sections 6.2 and 6.3, the authors estimated costs to construct a new compost installation (maximum build out) and to purchase new equipment for a compost operation. Composting will result in savings for disposal and waste handling costs, as well as a valuable soil amendment. However, there will also be costs associated with its operation. Appendix 6 illustrates spreadsheet calculation scenarios to estimate the breakeven time for any costs savings to play off the initial investment. For scenario 1, the authors estimated the initial investment for composting would be about $\$ 2.5$ million. If we estimate 2 full time employees (FTEs) (at $\$ 40 \mathrm{~K}$ per year each) to run the installation and operating costs on the order of $\$ 40 \mathrm{~K}$, we derive an annual operating costs of $\$ 120 \mathrm{~K}$. If we assume a waste diversion of 46 tons/week, disposal costs of $\$ 80$ per ton, and a savings of $\$ 25$ per ton of compost for offsetting fertilizer/soil amendment costs, we calculate an annual savings of about $\$ 25 \mathrm{OK}$. This gives a breakeven period of 19.1 years.

The breakeven period could be reduced by lowering the initiation costs, such as by choosing a lower cost build out, looking at used equipment, etc. If the construction costs could be reduced to $\$ 1.8$ million and the equipment costs reduced to $\$ 15 \mathrm{oK}$, the breakeven point would be reduced to just under 14.9 years (Scenario 2). It might be possible to reduce the labor requirements to $1 \mathrm{FTE}$, which would also reduce the breakeven point to 14.6 years (Scenario 3). Doing both reduced the breakeven point to just over 11.4 years (Scenario 4). Increasing the diversion can also improve the payoff period. If the diversion was increased by $50 \%$ (to 69 tons per week), the payoff period would be reduced to 9.7 years, assuming scenario 1 conditions (Scenario 5).

This simple analysis assumes all costs are fixed, which is not the actual case. Over time, salaries of the workers would be expected to rise and the 
other operating costs would likely increase as well; this would result in an increase in the amount of time it would take to meet the breakeven point. Similarly, disposal costs and fertilizer costs would be expected to rise; these factors would decrease the breakeven time. 


\section{Conclusions}

The following conclusions are derived from this study:

- On-site composting is a viable approach for managing vegetative, food, sludge, and unrecyclable paper at Ft. Polk:

- There are sufficient materials to generate a substantial amount of compost.

- A suitable area is available for a composting operation.

- The generated compost can be used on the installation and improve vegetation growth, control erosion; generated compost can also reduce the need for chemical fertilizers.

- Other options exist for some of the waste streams targeted by composting:

- Unrecyclable paper and sewage sludge can be directly applied to soil.

- Food and sewage sludge can be treated by anaerobic digestion, with the residuals being land applied. This can generate methane gas for heating purposes.

- Composting appears to be the most direct means of addressing all of these waste components.

- There appears strong potential for an off-site, regional composting operation:

- Deridder and Vernon Parishes have expressed interest.

- Boise-Cascade, which operates a large paper plant in Deridder Parish, can be a key industrial partner.

- Another option is to expand the current relationship with R\&W Farm.

- Some drawbacks of an outside-the-fence operation are that some materials might not be accepted for treatment and the installation would not have unlimited access to the compost. 


\section{References}

Alpert, P., and J. L. Maron. 200o. Carbon additions as a countermeasure against biological invasion by plants. Biological Invasions 2:33-40.

Bartle, A. 2011. Textile Waste. In Letcher, T. and Vallero, D. Waste: A handbook of waste management and recycling. Oxford, UK: Elsevier, Inc. Chapter 12.

Bernstad, A., and J. la Cour Jansen. 2012. Separate collection of household food waste for anaerobic degradation - comparison of different techniques from a systems perspective. Waste Management. In-press article published online: www.elsevier.com/locate/wasman.

Blumenthal, D. M., N. R. Jordan, and M. P. Resselle. 2003. Soil carbon addition controls weeds and facilitates prairie restoration. Ecological Applications 13:605-616.

Bonhotal, J., M. Schwarz, and G. Feinland. 2011. In-vessel composting options for medium-scale food waste generators. Biocycle 52: 49-54.

Brandon, D. L., V. F. Medina, and A. B. Morrow. 2011. A case history study of the recycling efforts from the United States Army Corps of Engineers Hurricane Katrina Debris Removal Mission in Mississippi. vol. 2011, Article ID 526256, 9 pages.

Brejda, J. J. 2000. Fertilization of native warm-season grasses. In Native warm season grasses: Research trends and issues (CSSA Special Publication Number 30), ed. K. J. Moore and B.E. Anderson.

Busby, R. R. 2003. Suitability of a municipal solid waste by-product as a soil amendment for reestablishing native grasses on disturbed Army training lands. MS thesis, University of Illinois, Urbana-Champaign.

Busby, R. R., D. L. Gebhart, and H. A. Torbert. 2006. Effects of an uncomposted municipal waste processing by-product on prairie grass establishment. Agronomy Journal 98:1073-1080.

Busby, R. R., H. A. Torbert, and D. L. Gebhart. 2007. Carbon and nitrogen mineralization of non-composted and composted municipal solid waste in sandy soils. Soil Biology and Biochemistry 39:1277-1283.

Campbell, A. G., R. L. Folk, and R. R. Tripepi. 1997. Wood as an amendment in municipal sludge and yard waste composting processes. Compost Science and Utilization $5: 62-73$.

Chang, J. I., and T. E. Hsu. 2008. Effects of compositions on food waste composting. Bioresource Technology 99:8068-8074.

Copinet, A., C. Bertrand, S. Govindin, V. Coma, and Y. Couturier. 2004. Effects of ultraviolet light $(315 \mathrm{~nm})$, temperature, and relative humidity on the degradation of polylactic acid plastic films. Chemosphere 55:763-773. 
Department of Defense (DoD). 2001. Base structure report: Fiscal year 2001 baseline. Office of the Deputy Undersecretary of Defense, Installations and Environment. Washington, DC: US Government Printing Office.

Devinny, J. S., M. S. Deshusses, and T. S. Webster. 1999. Biofiltration for air pollution control. Boca Raton, FL: CRC Press.

Donahue, D. W., J. A. Chalmers, and J. A. Stores. 1998. Evaluation of in-vessel composting of university postconsumer food wastes. Compost Science and Utilization 6:75-81.

Drake, L. D. 1983. Erosion control with prairie grasses in Iowa strip-mine reclamation. In Proceedings of the 7 th North American Prairie Conference, ed. C. L. Kucera, 189-197. Springfield, Miss.: University of Missouri.

Epstein, E. 1997. The science of composting. Lancaster, PA: Technomic Publishing Company.

Garcia-Pena, E. I., P. Parameswaram, D. W. Kang, M. Canul-Chan, R. Krajmalnik-Brown. 2011. Anaerobic digestion and co-digestion processes of vegetable and fruit residues: Process and microbial ecology. Bioresource Technology 102:9447-9455.

Garg, P., A. Gupta, and S. Satya. 2006. Vermicomposting of different types of waste using Eisenia foetida: A comparative study. Bioresource Technology 97:391-395.

Guisquiani, P. L., M. Pagliai, G. Gigliotti, D. Businelli, and A. Benetti. 1995. Urban waste compost: Effects on physical, chemical, and biological soil properties. Journal of Environmental Quality 24:175-182.

Haug, R. T. 1993. The principal handbook of compost engineering. Boca Raton, FL: Lewis Publishers.

Hoppenheidt, K., and J. Trankler.1995. Biodegradable Plastics and Biowaste Options for Common Treatment. Biowaste. 96 Conference. Aaborg, Denmark.

Jorgensen, K. S., J. Puustinen, and A-M. Suortti. 2000. Bioremediation of petroleum hydrocarbon-contaminated soil by composting in biopiles. Environmental Pollution 107:245-254.

Jung, G. A., J. A. Shaffer, and W. L. Stout. 1988. Switchgrass and big bluestem response to amendments on strongly acid soil. Agronomy Journal 80:669-676.

Launchbaugh, J. L. 1962. Soil fertility investigations and effects of commercial fertilizers on reseeded vegetation in west-central Kansas. Journal of Range Management 15:27-34.

Levy, D. B., E. F. Redente, and G. D. Uphoff. 1999. Evaluating phytotoxicity of Pb-Zn tailings to big bluestem (Andropogon gerardii Vitman) and switchgrass (Panicum virgatum L.). Soil Science 164 (6): 363-375. 
Keysar E., P. Brezovec, S. Siart. 2013. Reduced footprint base camp - systems integration support. Final mobile in-vessel composting demonstration/validation final report. National Defense Center for Energy and the Environment. Contact No. W91ZLK-10-D-005. Task 0720. Johnstown, PA: Concurrent Technologies Corporation..

Kim, J. D., P. Joon-Seok, I. Byung-Hoon, D. Dim, and W. Namkoong. 2008. Evaluation of pilot scale in-vessel composting for food waste treatment. Journal of Hazardous Materials 154:272-277.

Komilis, D. P., and R. K. Ham. 2000. A laboratory method to investigate gaseous emissions and solids decomposition during composting of municipal solid wastes. Compost Science and Utilization 8:254-265.

Komilis, D. P., and R. K. Ham. 2004. Life-cycle inventory of municipal solid waste and yard waste windrow composting in the United States. Journal of Environmental Engineering 130: 1390-1400.

Liang, Y., J. J. Leoanrd, J. J. R. Feddes, and W. B. McGill. 2006. Influence of carbon and buffer amendment on ammonia volatilization in composting. Bioresource Technology 97:748-761.

Mamo, M., T. R. Halbach, and C. J. Rosen. 1998. Utilization of municipal solid waste compost for crop production. Report FO-7083-GO 1998. Rochester, MN: University of Minnesota Extension Service.

McConnell, D. B., A. Shiralipour, and W. H. Smith. 1993. Compost application improves soil properties. Biocycle 33(I): 61-63.

McLendon, T., and E. F. Redente. 1992. Effects of nitrogen limitation on species replacement dynamics during early succession on a semiarid sagebrush site. Oecologia 91:312-317.

Medina, V. F., and S. A. Waisner. 2011. Military solid and hazardous wastes - assessment of issues at military facilities and base camps. In Letcher, T. and Vallero, D. Waste: A handbook of waste management and recycling. Oxford, UK: Elsevier, Inc. 25, 358-376.

Morgan, J. P. 1994. Soil impoverishment. Restoration and Management Notes 12:55-56.

National Bank for Agriculture and Rural Development (NBARD). 2007. Vermicomposting units under agri-clinics. Mumbai, India: Web-Werks Model Bank Projects.

National Defense Center for Energy and Environment (NDCEE). 2013a. Evaluation of composting for contingency bases. Rev. 1-13.

National Defense Center for Energy and Environment (NDCEE). 2013b. Demonstrating energy, waste, and wastewater technologies to reduce the footprint of contingency bases. Rev. 2-13.

Pagliai, M. and L. Vittori-Antisari. 1993. Influence of waste organinc matter on soil micro and macrostructure. Bioresource Technology 43:205-213. 
Paschke, M. W., T. McLendon, and E. F. Redente. 2000. Nitrogen availability and oldfield succession in a shortgrass steppe. Ecosystems 3:144-158.

Preston, K. T., S. Seiden, K. S. Ro. 1997. Bench-scale remediation composting: process, principles, and protocol. Technical Report IRRP-97-1. Available Online: http://el.erdc.usace.army.mil/elpubs/pdf/trirrp97-1.pdf.

Preston, K. T., R. Wade, K. S. Ro, S. Seiden, and M. Bergess. 1998. Bench-scale investigation of composting for remediation of explosives-contaminated soils from Iowa Army Ammunition Plant, Middletown, Iowa. Technical Report EL98-7. Vicksburg, MS: US Army Engineer Waterways Experiment Station.

Reever Morghan, K. J., and T. R. Seastedt. 1999. Effects of soil nitrogen reduction on nonnative plants in restored grasslands. Restoration Ecology 7:51-55.

Renkow, M. and A. R. Rubin. 1998. Does municipal solid waste composting make economic sense? Journal of Environmental Management 53:339-347.

Rippey, P. 2012. Analysis of Army Food Waste Streams. June-Aug. 2012. US Army Net Zero Briefing Slides. US Army Public Health Command.

Rynk, R., and M. Sailus. 1992. On-farm composting handbook. Ithaca, NY: National Resource, Agriculture, and Engineering Service.

Sarasa, J., J. M. Garcia, C. Javierre. 2009. Study of biodisintegration of bioplastic material waste. Bioresource Technology 100:3764-3768.

Skeel, V. A., and D. J. Gibson. 1996. Physiological performance of Andropogon gerardii, Panicum virgatum, and Sorghastrum nutans on reclaimed mine spoil. Restoration Ecology 4 (4): 355-367.

Tiqua, S. M., T. L. Richard, and M. S. Honeyman. 2002. Carbon, nutrient, and mass loss during composting. Nutrient Cycling Agroecosystems 62:15-24.

Torbert, H. A., D. L. Gebhart, R. R. Busby, K. N. Potter, and D. R. Curtin. 2007. Noncomposted municipal solid waste processing byproduct effect on soil reclamation. Communications in Soil Science and Plant Analysis 41:250-266.

Turner, M. S., G. A. Clark, C. D. Stanley, and A. G. Smajstrla. 1994. Physical characteristics of a sandy soil amended with municipal solid waste compost. Soil and Crop Science Society of Florida Proceedings 53:24-26.

US Composting Council (USCC). 1995. Factsheet: The benefits of including paper in composting. Ronkonkoma, NY: USCC.

. 2009. Best management practices for incorporating food residuals into existing yard waste composting operations. Bethesda, MD: USCC.

United States Environmental Protection Agency (USEPA). 2000. Biosolids technology fact sheet: In-Vessel composting of biosolids. EPA 832-00-061, Washington, DC: USEPA.

.2005. Municipal solid waste in the United States, 2005 facts and figures. Washington, DC: USEPA. 
. 2006. Putting surplus food to good use. Report Number EPAS30-F-06-004. Washington, DC: USEPA.

. 2009. Generators of food waste. www.epa.gov/epawaste/conserve/materials/organics/food.

. 2012. Putting surplus food to good use: A how-to guide for good service providers. EPA530-F-12-002. Washington, DC: USEPA

Van Gestel, K., J. Mergaert, J. Swings, J. Coosemans, and J. Ryckeboer. 2003. Bioremediation of diesel oil-contaminated soil by composting with biowaste. Environmental Pollution 125:361-368.

Warnes, D. D., and L. C. Newell. 1998. Establishment and yield responses of warm season grass strains to fertilization. Journal of Range Management 22:235-240.

Watts, D. B., F. J. Arriaga, H. A. Torbert, D. L. Gebhart, and R. R. Busby. $2012 a$. Ecosystem biomass, carbon, and nitrogen five years after restoration with municipal solid waste. Agronomy Journal 104:1305-1311.

Watts, D. B., F. J. Arriaga, H. A. Torbert, R. R. Busby, and D. L. Gebhart. 2012b. Noncomposted municipal solid waste by-product influences soil and plant nutrients five years after soil reclamation. Soil Science 177:480-489.

Wilson, S. D., and A. K. Gerry. 1995. Strategies for mixed-grass prairie restoration: Herbicide, tilling, and nitrogen manipulation. Restoration Ecology 3(4): 290298.

Zhang, H., K. H. Hartge, and H. Ringe. 1997. Effectiveness of organic matter incorporation in reducing soil compactibility. Soil Science Society of America Journal 61:239-245.

Zink, T. A. and M. F. Allen. 1998. The effects of organic amendments on the restoration of a disturbed coastal sage scrub habitat. Restoration Ecology 6:52-55. 


\section{Appendix A: Carbon-to-Nitrogen Ratios for Various Waste Items (from USCC 2009)}

\begin{tabular}{|c|c|c|c|}
\hline \multicolumn{4}{|c|}{ Appendix A: Carbon-to-Nitrogen Ratios for Select Waste Items ${ }^{11,12}$} \\
\hline Apple filter cake & 13 & Mussel waste & 2.2 \\
\hline Apple pomace ${ }^{a}$ & 48 & Newspaper ${ }^{a}$ & $400-850$ \\
\hline Apple processing sludge & 7 & Olive husks & $30-35$ \\
\hline Aquatic plants ${ }^{a}$ & $15-35$ & Paper (from domestic refuse) ${ }^{\mathrm{a}}$ & $125-180$ \\
\hline Blood meal ${ }^{\mathrm{a}}$ & 3 & Paper fiber sludge ${ }^{a}$ & 250 \\
\hline Broiler manure & 14 & Paper mill sludge ${ }^{a}$ & 55 \\
\hline Cardboard (corrugated) ${ }^{a}$ & 560 & Paper pulpa & 90 \\
\hline Castor pomace ${ }^{a}$ & 8 & Paunch manure ${ }^{a}$ & $20-30$ \\
\hline Cocoa shells ${ }^{a}$ & 22 & Pig manure ${ }^{a}$ & 14 \\
\hline Coffee grounds ${ }^{a}$ & 20 & Potato tops ${ }^{a}$ & 28 \\
\hline Compost ${ }^{\mathrm{a}}$ & $15-20$ & Potatoes (culled) & 18 \\
\hline Corn silage ${ }^{a}$ & $35-45$ & Potato processing sludge & 28 \\
\hline Corn stalks & $60-73$ & Poultry carcasses & 5 \\
\hline Corn wastes ${ }^{a}$ & $60-120$ & Rice hulls ${ }^{a}$ & $110-130$ \\
\hline Cottonseed meal ${ }^{\mathrm{a}}$ & 7 & Sawdust & 442 \\
\hline Cow manure $\mathrm{a}^{\mathrm{a}}$ & $10-30$ & Sawmill waste ${ }^{a}$ & 170 \\
\hline Crab/Lobster wastes & 4.9 & Seaweed ${ }^{\mathrm{a}}$ & $5-27$ \\
\hline Cranberry filter cake & 31 & Sheep manure & 16 \\
\hline Cranberry plants & 61 & Shrimp wastes ${ }^{a}$ & 3.5 \\
\hline Fish wastes & 3.6 & Shrub trimmings & 53 \\
\hline Fish--breading crumbs & 28 & Slaughterhouse wastes ${ }^{a}$ & $2-4$ \\
\hline Fish--processing sludge & 5.2 & Softwood bark ${ }^{\mathrm{a}}$ & $100-1000$ \\
\hline Food wastes ${ }^{a}$ & $14-16$ & Softwood chips, shavings ${ }^{\text {a }}$ & $200-1300$ \\
\hline Fruit wastes ${ }^{a}$ & 40 & Soil ${ }^{\mathrm{a}}$ & 12 \\
\hline Grass clippings & 17 & Soybean meal ${ }^{\mathrm{a}}$ & $4-6$ \\
\hline Hardwood bark ${ }^{a}$ & $100-400$ & Straw, general & 80 \\
\hline Hardwood chips, shavings ${ }^{a}$ & $450-800$ & Straw, oat ${ }^{\mathrm{a}}$ & 60 \\
\hline Hay, general & $15-32$ & Straw, wheat ${ }^{\mathrm{a}}$ & 127 \\
\hline Hay, legume ${ }^{a}$ & $15-19$ & Telephone books ${ }^{\mathrm{a}}$ & 772 \\
\hline Hay, non-legume & 32 & Tomatoe processing waste & 11 \\
\hline Hoof and horn meal ${ }^{a}$ & 3 & Tree trimmings ${ }^{a}$ & 16 \\
\hline Horse manure & 30 & Turkey litter ${ }^{\mathrm{a}}$ & 16 \\
\hline Laying hen manure & 6 & Vegetable wastes ${ }^{a}$ & $11-19$ \\
\hline Leaves & $40-80$ & Water hyacinths (fresh) & $20-30$ \\
\hline
\end{tabular}

figures in italic are average vakues

Source: NRAES-114, 1999. see References.

a Source: North Country Organics. See References. 


\section{Appendix B: Moisture Contents of Various Feedstocks (from USCC 2009)}

\begin{tabular}{|c|c|c|c|}
\hline \multicolumn{4}{|c|}{ Appendix B--Moisture Content of Select Feed Stocks ${ }^{12}$} \\
\hline Material & $\begin{array}{l}\% \text { by wt } \\
\text { (wet) }\end{array}$ & Material & $\begin{array}{l}\% \text { by wt } \\
\text { (wet) }\end{array}$ \\
\hline Apple filter cake & 60 & Newsprint & $3-8$ \\
\hline Apple pomace & 88 & Paper (from domestic waste) & 19 \\
\hline Apple processing sludge & 59 & Paper fiber sludge & 66 \\
\hline Breading crumbs & 10 & Paper mill sludge & 81 \\
\hline Broiler litter & 37 & Paper pulp & 82 \\
\hline Cattle manure & 81 & Paunch manure & $80-85$ \\
\hline Cocoa shells & 8 & Potato processing sludge & 75 \\
\hline Corn cobs & 15 & Poultry carcasses & 65 \\
\hline Corn silage & $65-68$ & \begin{tabular}{|l} 
Rice hulls \\
\end{tabular} & 14 \\
\hline Corn stalks & 12 & Sawdust & 39 \\
\hline Corrugated cardboard & 8 & Seaweed & 53 \\
\hline Cranberry filter cake & 50 & Sewage sludge & $72-84$ \\
\hline Crab and lobster wastes & 47 & Sheep manure & 69 \\
\hline Cranberry plant parts & 61 & Shrimp waste & 78 \\
\hline Cull potatoes & 78 & Shrub trimmings & 15 \\
\hline Fish processing sludge & 94 & Slaughterhouse waste & $10-78$ \\
\hline Fish processing waste & 76 & Straw & 12 \\
\hline Food waste & 69 & \begin{tabular}{|l} 
Swine manure \\
\end{tabular} & 80 \\
\hline Fruit wastes & 80 & Telephone books & 6 \\
\hline Grass clippings & 82 & Tomatoe processing waste & 62 \\
\hline Hay-general & 9 & Tree trimmings & 70 \\
\hline Horse manure w/bedding & 72 & Turkey litter & 26 \\
\hline Laying hen manure & 69 & Vegetable produce & 87 \\
\hline Leaves & 38 & Water hyacinth, fresh & 93 \\
\hline Mussel waste & 63 & & \\
\hline
\end{tabular}




\title{
Appendix C: Summary Article on Biodegradable Plastic Replacements (prepared by Dominique Gilbert)
}

\author{
Research: Biodegradable Plastic Products - draft 2/1/2013
}

\author{
Overview
}

1. Generic List of Commercial Products (go to page 11 for specific products)

- Below is a generic list of some of the many commercial biobased products (Biodegradable Plastics, n.d.; Leaversuch, 2002; Biodegradable Products Institute, 2003-2012). Films, agricultural films, traffic cones, industrial trays and commodity bags, disposable cutlery, food trays, hairbrush handles, and paper coatings (Leaversuch, 2002) loose-fill packaging, composting bags, fast-food tableware, nursery pots and plant labels (Biodegradable Plastics, n.d.), Carrier bags, refuse sacks (consumers buy in rolls for disposal of household waste), aprons (for garment protection), bags (for the collection of dog poop), Bin liners, gloves, plastic sheeting (for a variety of applications), plastic film for wrapping newspapers and magazines, bread bags, frozen food bags, wrappers for cigarette packets, shrink-wrap, pallet-wrap bubble-wrap, rigid products such as bottles and cups (IFT, 2013), Packaging and catering products, wrappings, egg cartons, razor handles, toys, food containers, laminated paper, films for agricultural applications (mulching films, low tunnel films, seed film, planting pots), disposable non-wovens (engineered fabrics), golf tees and hygiene products (diaper back sheets, cotton swabs) (Gross, 2002; Rudnik, 2008; Barker, 2009). Bioplastic polymers also used in more durable applications such as in textiles, consumer goods, automotive parts and building and construction (Song, 2009).

\section{Biodegradable Products}

- Biodegradable polymers (BDP), aka biodegradable plastics are produced from natural origins (e.g. plants, animals or micro-organisms), are derived from polysaccharides, proteins or lipids, (e.g. starch, cellulose, lignin and chitin; gelatin, casein, wheat gluten, silk and wool; or plant oils and animal fats, respectively) (Song, 2009).

- They are capable of decomposing into carbon dioxide, methane, water and inorganic compounds or biomass in which the primary mechanism is the enzymatic action of microorganisms (Song, 2009).

- Biodegradable plastics are generally plant-derived polymers, produced by converting plant sugars into plastic; producing the polymers inside a microorganism (bacteria), or growing the plastic inside the leaves or stalk of corn or other crops (Biodegradable Plastics, n.d.). 


\section{Compostability}

- Some BDPs are compostable but if they do not completely breakdown fragments they can be harmful for human health and to the environment (Narayan,

Biobased and biodegradable polymer materials: rationale, drivers, and technology exemplars. In Degradable Polymers and Materials, 2006a; Narayan, Rationale, drivers, standards, and technology for biobased materials. In Renewable resources and renewable energy, 2006b)

- $\quad$ NOT all BDP materials are biodegradable and vice versa (Song, 2009).

\section{Commercial Plastics (see tables 1 and 2 on page 9)}

- Many commercial BDP's combine materials from both Renewable (bio-based) and non-renewable (petrochemical-based) resources to reduce costs and/or enhance performance (Song, 2009). Therefore, BDP's, often comprise polymer blends containing partly biogenic (renewable) carbon derived from biomass and partly petrochemical carbon (Song, 2009).

- The 2 most prominent bioplastics are (Averos, 2013):

a) Polylactic acid (PLA):

b) Polyhydroxalkanoate (PHA)

- PLA

a) PLA is the most common BDP polymer on the market. It is derived from plants and involves converting plant sugars into plastic (Biodegradable Plastics, n.d.).

b) The bioplastics in PLA are produced from starches found in corn, wheat and potatoes (Davis, n.d.), as well as sugar beet, sugarcane, switchgrass, and other plants (IFT, 2013) fermented by lactobacillus organisms (Davis, n.d.). The lactic acid produced by these organisms is fused with polymers to create a plastic-like substance. Once in the trash, decomposers break the bonds between the polymers and lactic acid and degrade the material (Davis, n.d.).

c) These plastics are woven into fibers to make clothes in place of polyester (Quick, 2010).

\section{Environmental Benefits}

a) PLA production uses $65 \%$ less energy than production for conventional plastics, according to an independent analysis commissioned by NatureWorks (division of Cargill). It also generates $68 \%$ fewer greenhouse gases, and contains no toxins (Royte, 2006).

\section{Conditions for Decomposition}

a) Breaks down into water and carbon dioxide when exposed to bacteria (Harris, 1998-2013).

b) According to one source the plastic will decompose in less than 90 days if decomposition conditions are anaerobic and temperatures reach 140 Fahrenheit (Harris, 1998-2013; Royte, 2006).

c) These conditions are hard to achieve in landfill or in typical homecomposting systems (Harris, 1998-2013; Kapanen, 2012) where PLA can remain as long as petroleum-based plastics (Harris, 1998-2013) 1001000 years (Royte, 2006).

d) PLA in recycling centers causes other problems. Because PLA and 
petroleum based plastics don't mix (when broken down for recycling) they have to be separated which is expensive and time consuming (Harris, 1998-2013; Royte, 2006).

e) Large amounts of PLA also interfere with conventional composting because the polymer reverts into lactic acid, making the compost wetter and more acidic. Microbes will consume the lactic acid, but they demand a lot of oxygen, and for some facilities that much oxygen is difficult to provide.

Pros

a) In comparison to other BDP's prices for PLA are relatively low due to its market availability (ecomall, n.d.; Royte, 2006; Averos, 2013).

\section{Cons}

a) Price of each bottle is $5 \%-10 \%$ higher than regularly produced plastic bottles (Bowery, 2012).

b) Lower heat resistance limits its use because it degrade faster than traditional plastics (Quick, 2010).

c) Environmentalists say turning foodstuffs into packaging takes food from the hungry. In addition, industrially grown corn uses more nitrogen fertilizer, herbicides and insecticides than any other US crop.

- PH-A, -B, -V, -BV, -BHx, -BO, -Bod

\section{PHA}

a. Natural line of polymers (Averos, 2013) that are biodegradable in aerobic and anaerobic conditions. It is an intracellular storage product of bacteria and algae and is produced by microorganisms through a fermentation process. The plastics are extracted from the biomass after fermentation by solvent extraction (ecomall, n.d.).

b) Involves getting bacteria to produce granules of a plastic called polyhydroxyalkanoate (PHA) and poly-B-hydroxybutyrate (PHB) inside their cells. Bacteria are simply grown in culture, and the plastic is then harvested (Austrailian Academy of Science, 2002; Biodegradable Plastics, n.d.).

c) Scientists have also taken genes from these bacteria and stitched them into corn plants, which then manufacture the plastic in their own cells (Austrailian Academy of Science, 2002).

d) Evidence suggests that a variety of different microorganisms will form PHA's in large quantities under proper conditions (Biodegradable Plastics, n.d.).

e) Physically incompatible with main stream packaging wastes (PE, PP, ABS and PET) and aliphatic polyesters cannot be readily reprocessed with commercial polyesters, due to their thermal incompatibility (OxoBiodegradable Plastics Association, 2011)

Pros (Biodegradable Plastics, n.d.)

a) Evidence (see page 12) suggests they degrade quickly and completely (Biodegradable Plastics, n.d.) on land and at sea (Winter, 2012).

b) Good control of the chemical and physical properties of the polymer is possible (Biodegradable Plastics, n.d.).

c) PHAs are more versatile than most competing BDP's because they maintain their structure at up to $300 \mathrm{~F}$.

\section{Cons}


a) Relatively expensive in comparison to other BDP's ( $\$ 2.25$ to $\$ 2.75$ verses petroleum-based plastic which cost $60 \notin$ a pound) (Winter, 2012).

b) Product has a relatively low thermal decomposition temperature (OxoBiodegradable Plastics Association, 2011).

\section{- Another BDP of Interest}

\section{Oxo Biodegradable}

a) This one is also bio-assimilated by bacteria and fungi, which convert the degraded plastic to cell biomass, just like lignocellulose materials like straw, leaves and twigs (Oxo-Biodegradable Plastics Association, 2011).

b) It's made from a byproduct of oil or natural gas, and still relies on nonrenewable resources (Oxo-Biodegradable Plastics Association, 2011).

c) Length of time it takes for Oxo-biodegradable products to degrade can be programmed '(determined by quantity of BDP it is manufactured with) at the time of manufacture and can be as little as a few months or as much as a few years (Oxo-Biodegradable Plastics Association, 2011).

\section{Conditions for Decomposition}

a) Decomposes best in the oxygen-rich environments provided by large industrial composting tanks, equipment not found in typical landfills or backyards (Oxo-Biodegradable Plastics Association, 2011).

b) It can be recycled with normal plastic waste stream (Oxo-Biodegradable Plastics Association, 2011).

c) According to the Oxo-Biodegradable Plastics Association (BPA) ecotoxicity tests have demonstrated that traces remaining after degradation are such minor parts per million that no harmful effects occur (OxoBiodegradable Plastics Association, 2011).

d) Because Oxo bio products biodegrade after their molecular weight has reduced to the point where naturally-occurring micro-organisms can access them (Oxo-Biodegradable Plastics Association, 2011) (OxoBiodegradable Plastics Association, 2011).

i. First they degrade then biodegrade. BPA claims the can degrade on land, sea, in light or dark, heat or cold, and on whatever timescale required, leaving at the end of the process $\mathrm{NO}$ fragments and NO harmful residues (Oxo-Biodegradable Plastics Association, 2011).

e) In the first phase of the degradation process the formulation breaks the molecular chains so that the material can no longer be considered a plastic but a material with an entirely different molecular structure. The material does not just fragment, but will be consumed in the second phase by bacteria and fungi after the formulation has reduced the molecular weight to a level which permits living micro-organisms access to the carbon and hydrogen (Oxo-Biodegradable Plastics Association, 2011).

f) This process continues until the material has biodegraded to nothing more than $\mathrm{CO} 2$, water, and humus (Oxo-Biodegradable Plastics Association, 2011). Length of the useful life of an Oxo-biodegradable plastic product is determined by antioxidants (processing stabilizers and UV stabilizers) contained within the formulation, which can be modified 
so that the plastic product degrades according to whatever timescale is required. Oxo-biodegradable plastic can be programmed at manufacture to degrade within a timescale to suit the user's requirements (OxoBiodegradable Plastics Association, 2011).

g) Oxo-biodegradable plastic do not degrade quickly in low temperature in windrow composting, but development is ongoing with in -vessel composting as the temperatures are higher (Oxo-Biodegradable Plastics Association, 2011).

Cons

a) Not good deep in landfill (Oxo-Biodegradable Plastics Association, 2011)

b) Many contain up to $50 \%$ of synthetic plastic derived from oil, and others (e.g. some aliphatic polyesters) are entirely based on oil-derived intermediates (Oxo-Biodegradable Plastics Association, 2011).

c) In February 2011 a life cycle assessment was published by the UK Environment Agency, which showed that Oxo-biodegradable plastic bags have a better LCA than paper bags or compostable plastic bags (Oxo-Biodegradable Plastics Association, 2011).

Pros

a) Plastic bags are extremely compact. Plastic grocery bags and all plastic retail bags together take up less than $1 \%$ of space in landfills. (OxoBiodegradable Plastics Association, 2011)

b) Little or no additional cost, because it is made with same machines and workforce, as ordinary plastics, and uses same low-cost raw materials (Oxo-Biodegradable Plastics Association, 2011).

c) It is thinner and requires less space to store and transport, and less material to produce (Oxo-Biodegradable Plastics Association, 2011).

d) And because they are thinner and lighter than traditional plastics, less energy is required to produce and transport them (Oxo-Biodegradable Plastics Association, 2011).

e) They can be made with the same workforce and machinery as conventional plastic products (Oxo-Biodegradable Plastics Association, 2011).

f) Plastic bags from these plastics are extremely compact (OxoBiodegradable Plastics Association, 2011).

\section{Different Types of Biodegradable Plastics}

\section{PLA}

- Cargill (USA) manufactures a PLA under the trademark NatureWorks (Royte, 2006)

a) Cargill (the largest corn merchant) is located 30 mins. North of Omaha, is the largest lactic-acid plant in the world - producing the white pellets that are the industrial resin that is PLA (corn based kind).

b) At the time of publication Wal-Mart planned for PLA containers (114 million PLA containers a year) for produce and high-end electronics, 
Newman's Own Organics uses PLA packaging for its salad mixes, Wild Oats uses PLA products, Google's uses PLA trays in their cafeteria, the George Lucas (filmmaker) uses PLA products trays and Del Monte and Meijer stores use PLA for their fresh cut fruits.

- Dainippon Ink and Chemicals (Japan) -- CPLA

a) Combines polyester and PLA properties into one polymer developing a biodegradable copolymer called CPLA based on a copolyester plus lactic acid. A higher ratio of copolyester increases flexibility, while more lactic acid adds stiffness.

b) These materials are miscible with numerous other polymers and are inherently biodegradable, though they have low melting points and are expensive.

\section{PH-A, -B, -V, -BV, -BHx, -BO, -Bod}

\section{- Proctor \& Gamble Co. (USA)}

a) Nodax is a PHBH

i. Developing large range of polyhydroxybutyrate cohydroxyalkanoates (PHBHx, PHBO, PHBOd). Industrial production not in the plan. (Averos, 2013).

ii. Material properties are tailored by varying the HV content. An increase of $\mathrm{HV}$ induces increases in impact strength of genetic material (Averos, 2013).

\section{Generic Products}

iii. Used in packaging, diapers and clothing (ecomall, n.d.).

- Metabolix and ADM (USA) (PHB, PHBV or polyhydroxybutyrate valerate) bought Biopol ${ }^{\circledR}$ assets (originally manufactured by Monsanto) in 2001 (Averos, 2013).

a) Biopol ${ }^{\circledR}$ trade developed the genetic modification of plants to make them produce small quantities of PHB (Averos, 2013).

b) Monsanto produced a large range of bacterial copolymer grades, with HV contents reaching 20\% (Averos, 2013).

c) Metabolix looking to use switchgrass instead of corn (Winter, 2012)

- Copersucar-Biocycle (PHB Industrial-Brazil).

a) Small company that produces PHBV from sugar cane molasses (Averos, 2013).

- Polargruppen (Norway) - uses Novamont's Mater-Bi polymer (ecomail)

a) Uses Mater-Bi starch (available through Norsea BioSystems in Edmonds, WA).

b) Certified by DIN Certco in Germany and "OK Compost" in other parts of Europe.

c) Bags, bin liners, agricultural mulch and food packaging.

\section{Biodegradable Petroleum Based Polyesters}

- Aliphatic copolyesters (Averos, 2013) 
a) A large number of aliphatic copolyesters are biodegradable copolymers based on petroleum resources - products; biodegradability depends also on the structure.

b) Addition of adipic acid, which decreases the crystalinity, tends to increase the compost biodegradation.

- DuPont (USA) (ecomall, n.d.)

a) Biomax polyethylene terephthalate copolymer (hydro/biodegradable polyesters - the added polymers make weak spots, making the Biomax polymer hydrodegradable - once moisture breaks polymer down microbes can consume material.

b) Available in US and overseas.

\section{Generic Products}

a) Fast-food disposable packaging, yard-waste bags, diaper backing, agricultural film, flower pots, and bottles (Leaversuch, 2002).

- Showa Highpolymer (Japan) has developed a large range of these polybutylene succinate/adipate (PBS, PBSA) (Averos, 2013).

a) The copolymers are commercialized under the Bionolle ${ }^{\circledR}$ trade mark.

b) PBSA is inherently biodegradable, the addition of a starch filler significantly improves the rate of degradation.

c) PBSA is obtained by addition of adipic acid.

d) Offer resins in US (Leaversuch, 2002).

- Ire chemical (Korea) commercializes the same copolyesters under EnPol ${ }^{\circledR}$ trade mark.

- SK Chemicals (Korea) manufactures Skygreen ${ }^{\circledR}$ (Averos, 2013)

a) Offer resins in US (Leaversuch, 2002).

- Nippon Shokubai (Japan) commercializes aliphatic copolyesters with Lunare SE® trademark. (Averos, 2013)

- Polargruppen (Norway) - uses Novamont's (ecomall, n.d.) (former Italian Company produced under trademark Origo-Bi (Averos, 2013)) and Mater-Bi polymer (ecomall, n.d.)

a) Mater-Bi starch (available through Norsea BioSystems in Edmonds, WA) (ecomall, n.d.)

\section{Generic Products}

a) Bags, bin liners, agricultural mulch and food packaging (ecomall, n.d.).

- BASF (Germany) commercialize aromatic copolyesters with Ecoflex ${ }^{\circledR}$ (Averos, 2013)

a) Research suggests no environmental risk (ecotoxicity) when aliphaticaromatic copolyesters of the Ecoflex-type are introduced into composting process (Witt, Einig, Yamamoto, Kleeberg, Deckwer, \& Muller, 2011).

b) Ecoflex is an aromatic-aliphatic copolyester based on butanediol, adipic acid, and terephthalic acid, BASF's products contain long-chain branching (Leaversuch, 2002).

\section{Oxo Bio Products}

- Leading UK supermarkets are now using Oxo-biodegradable plastic products. 
- In Portugal the country's largest retail group, Sonae, has adopted Oxobiodegradable plastic for their Continent, Mondelo and Mondelo Bonjour supermarket chains.

- Other users include TigerBrands South Africa, the Inditex Group26 (owners of Zara) as well as Bimbo Group of Bakeries in Latin America, the Marriott Hotels, BUPA Care Homes, Subway fast food chain, News International, Pizza Hut, KFC, French Railways, The Brazilian Post Office, Barclays Bank, and Walmart (Argentina) (Oxo-Biodegradable Plastics Association, 2011). 
Table 1: Biodegradable polymers from renewable and petroleum sources by feedstock, trade name and company where possible (Averos, 2013; Rudnik, 2008)

\begin{tabular}{|c|c|c|c|}
\hline Polymers for renewable sources & $\begin{array}{l}\text { Primary feedstock } \\
\text { /synthesis }\end{array}$ & Trade Names & Company \\
\hline PLA polylactide & $\begin{array}{l}\text { Lactic acid by chemical } \\
\text { synthesis or carbohydrate } \\
\text { fermentation }\end{array}$ & $\begin{array}{l}\text { Lacea, Lacty, Nature } \\
\text { Works, Hycail, Heplon, } \\
\text { CPLA, Futero, PLA, } \\
\text { Biofront, L-PLA }\end{array}$ & $\begin{array}{l}\text { Cargil (USA-Japan), } \\
\text { Shimadzu (Japan), } \\
\text { Mitsui Chemicals (Japan), } \\
\text { Chronopol (USA), } \\
\text { Dainippon Ink Chem (Japan), } \\
\text { Total /Galactic (Belgium), } \\
\text { Galactic (Belgium), } \\
\text { Teijin (Netherlands), } \\
\text { Purac (Netherland), } \\
\text { Xhejiang Hisun Biomaerials (China) }\end{array}$ \\
\hline $\begin{array}{l}\text { PHA poly(hydroxyalkanoates) } \\
\text { PHB poly(3-hydorxybutyrate) } \\
\text { PHV poly(3-hydorxyvalerate) } \\
\text { PHBV poly(3-hydorxybutyrate-co-3-hydroxyvalerate) }\end{array}$ & $\begin{array}{l}\text { Synthesized by bacteria } \\
\text { (carbohydrates, alkanes, } \\
\text { organic acids, etc.) }\end{array}$ & $\begin{array}{l}\text { Biopol@, Kaneka, } \\
\text { Nodax®, Tirel, Enmat, } \\
\text { Biocycle, Biomer L }\end{array}$ & $\begin{array}{l}\text { Metabolix/ADM (USA), Tianen (China), } \\
\text { Copesucar (Brazil), } \\
\text { Biomer (Germany), } \\
\text { Procter and Gamble (USA) }\end{array}$ \\
\hline $\begin{array}{l}\text { PHBHx polyhydroxybutyrate co-hydroxyhexanoate } \\
\text { PHBO polyhydroxybutyrate co-hydroxyoctonoate , PHBOd } \\
\text { polyhydroxybutyrate co-hydroxyoctadecanoate }\end{array}$ & & & \\
\hline TPS thermoplastic starch & Starch & $\begin{array}{l}\text { Solanyl, Bioplast TPS, } \\
\text { EverCorn, Plantic, } \\
\text { Biopar, Placorn }\end{array}$ & \\
\hline $\begin{array}{l}\text { Cellulose: } \\
\text { CA cellulose acetate }\end{array}$ & $\begin{array}{l}\text { Esterification of cellulose } \\
\text { (wood, cotton, hemp, sugar } \\
\text { cane, corn etc.) }\end{array}$ & $\begin{array}{l}\text { Ntureflex, Tenite, } \\
\text { Bioceta, Cellidor }\end{array}$ & \\
\hline CAP cellulose propionate & & & \\
\hline CAB cellulose acetate butyrate & & & \\
\hline
\end{tabular}




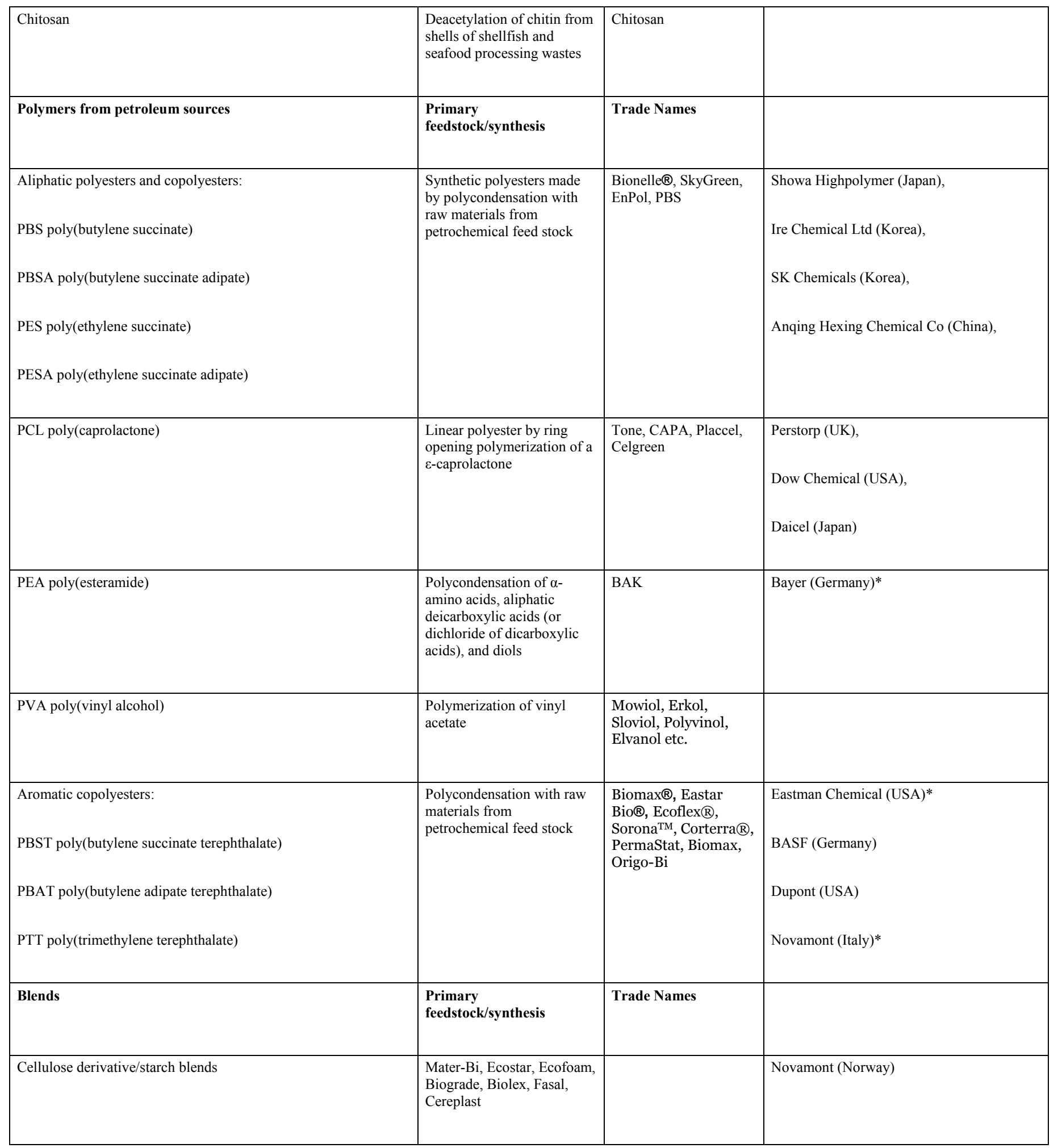

* Bankrupt or no longer being produced (Averos, 2013; ecomall, n.d.) 
Table 2: Biodegradation of main commercial biopolyesters (Averos, 2013)

\begin{tabular}{|l|l|l|l|l|l|}
\hline $\begin{array}{l}\text { PLA } \\
\text { Dow-Cargill (Nature } \\
\text { Works) }\end{array}$ & $\begin{array}{l}\text { PHBV } \\
\text { Monsanto (Biopol } \\
\text { DH400G) HV=7 mol } \\
\%\end{array}$ & $\begin{array}{l}\text { PCL } \\
\text { Solway (CAPA 680) }\end{array}$ & $\begin{array}{l}\text { PEA } \\
\text { Bayer (BAK 1095) }\end{array}$ & $\begin{array}{l}\text { PBSA } \\
\text { Showa } \\
\text { (Bionolle 3000) }\end{array}$ & $\begin{array}{l}\text { PBAT } \\
\text { Eastman (easta } \\
\text { bio 14766) }\end{array}$ \\
\hline $\begin{array}{l}\text { Biodegradation / } \\
\text { Mineralization } \\
(\%)\end{array}$ & 100 & 100 & 100 & 90 & 100 \\
\hline
\end{tabular}




\section{Plastics By Company Name}

\section{Specific Biobased Products (Leaversuch, 2002)}

- Synthetic biodegradable polyesters also play a role in thermoformed trays for fresh produce and meat, as well as disposable plates, bowls, and cups.

- Earthshell composite consists of cellulose from paper waste, starch from potato waste, ground limestone, and water.

a) Earthshell and DuPont have formed an alliance to serve the disposable food-service market, including plates, hinged clamshells, hot and cold cups, and more.

- Apack's trays are being used for organic produce by two top U.K. supermarket chains as a replacement for EPS foam trays. Apack meat trays have a base similar to that of the produce tray. Their packaging is being tested for poultry in the US

- DuPont is concentrating on a new flexible sandwich wrap for fast-food chains.

a) DuPont's Biomax polyester is one of several ingredients in the Nature Partners sandwich wrap.

\section{Standards Certifications for Biodegradable Products}

- The American Society for Testing and Materials (ASTM) is an international testing authority that determines voluntary consensus on technical standards for a wide range of materials, products, systems, and services. The organization establishes the Standard Specifications that defines the requirements to be satisfied by subject of the standard. They also define

- The Standard Test Methods, that parameterize the way a test is performed and the precision of the result.

- The three main standards for biodegradable products are (Biodegradable Products Institute, 2003-2012):

a) ASTM 6868: Test to determine if a biodegradable plastic is truly biodegradable.

b) ASTM 6400: Test to certify if a product can be composted.

c) EN14342 (European standard): European test to determine biodegradability of plastics.

- PLA plastic technology, compostable, ASTM certified compostable, or a combination thereof: Specific Products by Company (Biodegradable Products Institute, 2003-2012):

a) Nature Works (a division of Cargill)

i. World Centric ${ }^{\mathrm{TM}}$ 3" Compostable Tasting Spoon by Nature Works

ii. Compostable Corn Plastic Sushi Trays

iii. Food Containers

b) Eco Products (trademark of Waddington North America)

iv. Compostable PLA Salad Bowls with Lids

v. Compostable Corn Plastic Sushi Trays

vi. Green Stripe Compostable Hot Cups

vii. Compostable Containers 
c) Ecotainer (trade mark of Paper International)

viii. Carte Blanc ${ }^{\mathrm{TM}}$ Hot Cup

d) Greenware (trade mark of Fabri-Kal)

ix. Print Compostable Corn Cups, Lids, and straws (made from Nature Works PLA plastic)

e) EcoSafe (trade mark of Plastic Solutions Inc.)

x. 6400 Compostable Trash Bags

- Oxo bio products by Company advertised as incorporation plastic technology:

a) Pride Green Technology

b) 13-gallon Tie \& Drawstring Tall Kitchen Bags

- Natur-Bag-ASTM 6400 certified (manufactured by Northern Technologies International Corp)

- Mater-Bi product (not clear which company produces this bag liner) (http://www.spiritofnature.co.uk/products/straight/compost-a-bag-bin-liners/)

a) Compost-A-Bag Bin Liners

\section{Research Supporting Biodegradability of above Plastics}

\section{PLA research}

- Research has demonstrated that the extent of degradation increases with higher process temperatures. The ester linkage is the primary mechanism for degradation of PLA. On the basis of this data, PLA degradation was suggested. (Agarwal M., 1998)

- Decomposers and their enzymes can be used for the effective biological treatment of plastic wastes containing PLA (Tokiwa Y., 2004).

\section{Oxo-bio research}

- Research reviewed by the authors here leave no question that some plastics made from natural resources do rapidly convert to carbon dioxide and water. However, the research on the biodegradability for Oxo bio's also confirms that it can take longer, which for certain applications is better as certain uses for the polyolefins require them to be longer lasting.

- The authors in this paper also do affirm that the ASTM testing protocol does indeed identify plastics and other polymers that can meet the designated criteria even though the authors acknowledge many of these do not biodegrade solely as a result of microbial activity.

- Authors cite research that shows that when Oxo-biodegradable polyethylene films is subjected to $70 \mathrm{C}$, the films experience an over $60 \%$ conversion to carbon dioxide in just over 6 months. In other works cited the authors say that after relatively mild thermal oxidative conditions (55 C) Oxo-biodegradable polyethylene substantially converted to $\mathrm{CO} 2$ within 18 months when incubated with both soil and mature compost. The authors make the point that this takes place over three years, which is a shorter time than what is required for the mineralization of straw on soil (Scott G., 2001). 


\section{Mater-Bi (Long, 2010)}

- Mother Earth News tested five types of bioplastic bags to see how well they would compost. They found that under home composting conditions, bags were still decomposing after 25 weeks. They found that a product from the Italian bioplastic manufacturer Novamont with their Mater-bi product came closest to truly compostable.

- Mother Earth News found that while three other brands did well in commercial composting conditions, they did not degrade well, if at all, in home compost conditions and one t-Biodegradable, did not begin to break down until after 25 weeks at 140 degrees.

- In the Bloomberg BusinessWeek Magazine article the author cites Jo Ann Ratto, a polymer research engineer with the US Army (Army's Natick Soldier Research, Development and Engineering Center) who studies plastics. Apparently Ratto ran a study looking at how well biodegradable materials decompose in ocean waters. Apparently the study revealed that the samples of cellophane and polylactic acid, two commonly used biodegradables, lost less than $20 \%$ and less than $1 \%$ of their mass, respectively. The PHA samples, however, completely disappeared in less than five weeks. According to Ratto this kind of degradation in marine environments is rare (Winter, 2012).

\section{Biodegradable packaging materials}

- Study showed that biodegradable packaging materials exhibited a wide range of biodegradation properties in simulated home composting systems run under nonthermophilic conditions (where mesophilic micro-organisms dominate). Thus, it was concluded that mesophilic home composting conditions might be less favorable for biodegradation than those specified in some standards.

Nevertheless, the home composting system used in this study operated over a temperature range of approximately $5-18^{\circ} \mathrm{C}$ rather than the $20-30^{\circ} \mathrm{C}$ range specified in the OK Compost Home standard (a certified system) (Klauss M., 2004). 


\section{Bibliography}

Agarwal M., K. K. (1998). Characterization of the degradation of polylatic acid polymer in a solid substrate environment. Biotechnol. Prog , 14, , 517-526.

Austrailian Academy of Science. (2002, February). Nova Science in the News:MAKING PACKAGING GREENER - BIODEGRADABLE PLASTICS. Retrieved January 22, 2013, from Austrailian Academy of Science: http://www.science.org.au/nova/061/061key.html

Averos, L. (2013, February 1). - Bioplastics - Biodegradable polyesters (PLA, PHA, $P C L$...). Retrieved February 1, 2013, from Pr. Luc Averous: Biodegradable and Biobased Polymer, Biopolymer, Agro-polymer, Bioplastic, Biomaterial, Compostable Packaging : http://www.biodeg.net/bioplastic.html

Barker, M. S. (2009). Industrial uses for crops: markets for bioplastics. London: Caledonia House.

Biodegradable Plastics. (n.d.). Retrieved Januray 24, 2013, from University of Michigan Engineering:

http://www.engin.umich.edu/labs/EAST/me589/gallery/bioplastics_f01/599Webs

ite/BiodegradablePlastics.htm

Biodegradable Products Institute. (2003-2012). Definitions \& Standards of Biodegradability. Retrieved February 3, 2013, from Biodegradable Products Institute: http://www.bpiworld.org/science-of-composting

Bowery, B. (2012, November 5). How are biodegradable plastics made? Retrieved January 24, 2013, from Helium: Where Knowledge Rules: http://www.helium.com/items/2388392-how-are-biodegradable-plastics-made

Davis, J. (n.d.). Green Living: Biodegradable Items That Can Replace Plastic. Retrieved January 24, 20013, from National Geogrpahic: http://greenliving.nationalgeographic.com/biodegradable-items-can-replaceplastic-20151.html

ecomall. (n.d.). ecomall: A Place to Help Save the Earth. Retrieved January 24, 2013, from DEGRADABLE PLASTICS FOR COMPOSTING:

http://www.ecomall.com/greenshopping/biocycle.htm

Gross, R. K. (2002). Biodegradable polymers for the environment. Science , 297, 803-807. 
Harris, W. (1998-2013). howstuffworks? Retrieved January 24, 2013, from Do we need biodegradable plastics?: http://science.howstuffworks.com/science-vsmyth/everyday-myths/do-we-need-biodegradable-plastics.htm IFT. (2013, January 16). Using pulp for biodegradable plastic in disposable food containers. Retrieved January 24, 2013, from IFT: Feeding the minds that feed the world: http://www.ift.org/Food-Technology/Daily-

News/2013/January/16/Using-pulp-for-biodegradable-plastic-in-disposablefood-containers.aspx

Kapanen, A. (2012). Some experiments demonstrate: fast degraders loose approximately $90 \mathrm{wt} \%$ and became visually indistinguishable from their sealed packets; medium degraders loose approximately $50 \mathrm{wt} \%$ and remain recognizable on close inspection. Slow degraders loose typically less than 5 wt\% and are clearly recognizable. - biodegradable packaging materials exhibit wide range of biodegradation properties in simulated home composting system run with non-thermophic conditions (where mesophilic micro-organisms dominate). elevated temperature around $60^{\circ} \mathrm{C}$ is a crucial, enabling the induction of biodegradation of polymers such as PLA (e.g. Agarwal et al. 1998; Scott \& Wiles 2001; Tokiwa \& Jarerat 2004). . University of Helsinki. Espoo: Julkaisija-Utgivare.

Klauss M., B. W. (2004). Biodegradable polymer packaging: practical experiences of the model project Kassel. Proceedings of the 1st UK Conference and Exhibition on Biodegradable and Residual Waste Management (pp. 382-388). Harrogate: CalRecovery Europe Ltd.

Leaversuch, R. (2002, September). BIODEGRADABLE POLYESTERS: PACKAGING GOES GREEN. Retrieved January 22, 2013, from Plastic Technology: http://www.ptonline.com/articles/biodegradable-polyesters-packaging-goesgreen

Long, S. (2010, July). The Truth About Biodegradable Plastics. Retrieved January 24, 2013, from Mother Earth News: the original guide to living wisely: http://www.motherearthnews.com/nature-community/the-truth-aboutbiodegradable-plastics.aspx\#ixzz2JPvenxkl

Narayan, R. (2006a). Biobased and biodegradable polymer materials: rationale, drivers, and technology exemplars. In Degradable Polymers and Materials. In P. F.

Mauro Graziani (Ed.), Degradable Polymers and Materials: Principles and Practice (Vol. 939, p. 282). American Chemical Society. 
Narayan, R. (2006b). Rationale, drivers, standards, and technology for biobased materials. In Renewable resources and renewable energy. In F. P. eds Graziani M. (Ed.), Renewable Resources and Renewable Energy: A Global Challenge (Vol. 939, p. 282). Boca Raton, FL.

Oxo-Biodegradable Plastics Association. (2011). Briefing Note on Biodegradable Plastics. Oxo-Biodegradable Plastics Association. London: Oxo-Biodegradable Plastics Association.

Quick, D. (2010, November 18). Making tougher biodegradable plastics from plants. Retrieved 124,2013 , from gizmag: http://www.gizmag.com/tougherbiodegradable-plastic-pla/16993/

Royte, E. (2006, August). Corn Plastic to the Rescue. Retrieved January 24, 2013, from Smithsonian.com: http://www.smithsonianmag.com/sciencenature/plastic.html\#ixzz2JgyylczV

Rudnik, M. (2008). Compostable polymer materials. Oxford, England: Elsevier.

Scott G., W. D. (2001). Programmed-life plastics from polyolefins: a new look at sustainability. Biomacromolecules , 2, 615-622.

Song, J. M. (2009, June 14). Biodegradable and compostable alternatives to conventional plastics. Retrieved January 22, 2013, from The Royal Society: http://rstb.royalsocietypublishing.org/content/364/1526/2127.full

Tokiwa Y., J. A. (2004). Biodegradation of poly(L-lactide). Biotechnol. Lett. , 26,, 771-777.

Winter, C. (2012, January 5). Environment: Keeping the Sea Safe from Plastic. Retrieved 122 , January, from Bloomberg Business Week Magazine: http://www.businessweek.com/magazine/keeping-the-sea-safe-from-plastic01052012.html

Witt, U., Einig, T., Yamamoto, M., Kleeberg, I., Deckwer, W., \& Muller, R. (2011). Biodegradation of aliphatic-aromatic copolyesters: evaluation of the final biodegradability and ecotoxicological impact of degradation intermediates. Chemosphere , 44 (2), 289-299. 


\title{
Appendix D: Phone meeting notes from discussion with Joey Breaux, Louisiana Office of Soil and Water Conservation
}

\author{
LA BMP vs permit (UNCLASSIFIED) \\ Kemme, Patricia ERD-IL
}

Wed 8/14/2013 2:48 PM

Classification: UNCLASSIFIED

Caveats: NONE

I just spoke to Joey Breaux of the Louisiana Office of Soil and Water Conservation. Joey stated that a BMP could be allowed not only for yard and wood waste but also food waste. The DEQ may add some language to the BMP to make it acceptable. The BMP would not allow paper, plastic or sewage sludge. A BMP does not have any fees attached. Joey seemed very willing to help. He is now expecting a call from Charles Stagg at Ft Polk. In addition someone around Ft Polk is also investigating a compost facility start up. The office number is 225-922-1269

The Type III compost landfill permit application costs $\$ 660$. In addition, an annual monitoring and maintenance fee of $\$ 660$ is also required. Type III compost facilities have no additional tonnage fees (Found the pricing structure in LAC 33, VIII, 1501 and 1505).

Classification: UNCLASSIFIED

Caveats: NONE 


\section{Appendix E: Cost Estimate for Preparing an On-Site Composting Operation (with references to R.S. Means construction estimating factors)}




\begin{tabular}{|c|c|c|c|c|c|}
\hline Action & Quantity & UOM & Cost/unit & Total Cost & \begin{tabular}{|l} 
Means Ref. No./ \\
Subtotals
\end{tabular} \\
\hline \multicolumn{6}{|l|}{ Ft. Polk Composting Facility } \\
\hline \multicolumn{6}{|l|}{ Prepare area } \\
\hline Clear, grub, and remove top soil & - & - & - & - & - \\
\hline Clear and grub & 7 & acres & $\$ 1,125.00$ & $\$ 8,326.45$ & 311313100300 \\
\hline Strip away bad top soil & 5,970 & CY & $\$ 1.76$ & $\$ 10,507.85$ & 311413230100 \\
\hline Load 'bad' top soil into dump trucks & 5,970 & CY & $\$ 1.24$ & $\$ 7,403.26$ & 312316421650 \\
\hline Haul away 'bad' top soil in dump trucks & 5,970 & CY & $\$ 12.75$ & $\$ 76,122.22$ & 312323201102 \\
\hline Install new 6" 'base' material for facilit & - & - & - & - & - \\
\hline Load fill material (clay type material) to & 5,777 & CY & $\$ 1.24$ & $\$ 7,163.78$ & 312316421650 \\
\hline Haul in fill material by dump truck & 5,777 & CY & $\$ 12.75$ & $\$ 73,659.86$ & 312323201102 \\
\hline Spread fill material throughout & 5,777 & CY & $\$ 2.03$ & $\$ 11,727.80$ & 312323170020 \\
\hline Grade fill material & 35,822 & SY & $\$ 0.84$ & $\$ 30,090.67$ & 312216100100 \\
\hline Compact fill material & 5,777 & $\mathrm{CY}$ & $\$ 1.39$ & $\$ 8,030.37$ & 312323240400 \\
\hline Compact fill material & 5,777 & CY & $\$ 1.39$ & $\$ 8,030.37$ & 312323240400 \\
\hline Total & & & & & $\$ 241,062.63$ \\
\hline & & & & & \\
\hline \multicolumn{6}{|l|}{ Install fencing } \\
\hline Install new fencing, poles $10^{\prime}$ on center, & 2,280 & LF & $\$ 47.50$ & $\$ 108,300.00$ & 323113200920 \\
\hline Install double gates, $8^{\prime}$ high, $12^{\prime}$ wide & 2 & Ea & $\$ 3,600.00$ & $\$ 7,200.00$ & 323113205090 \\
\hline Total & & & & & $\$ 115,500.00$ \\
\hline & & & & & \\
\hline \multicolumn{6}{|l|}{ Build run off pond } \\
\hline Excavate and form pond & - & - & - & - & - \\
\hline Excavate for run off pond & 14,130 & $C Y$ & $\$ 5.45$ & $\$ 77,009.51$ & 312316462210 \\
\hline Pile soil to load into truck & 14,130 & $\mathrm{CY}$ & $\$ 0.15$ & $\$ 2,119.53$ & 312316420020 \\
\hline Remove excess soil/load into truck & 14,130 & CY & $\$ 1.24$ & $\$ 17,521.43$ & 312316421650 \\
\hline Haul excess soil away 10 mile trip & 14,130 & CY & $\$ 12.75$ & $\$ 180,159.87$ & 312323201102 \\
\hline Grade and/or form run off pond & 10,777 & SY & $\$ 0.84$ & $\$ 9,052.79$ & 312216100100 \\
\hline \multicolumn{6}{|l|}{ [liner] } \\
\hline Total & & & & & $\$ 285,863.13$ \\
\hline & & & & & \\
\hline \multicolumn{6}{|l|}{ Install perimeter lights } \\
\hline Install power lines for security lights & - & - & - & - & - \\
\hline Trench for cable to power lights & 2,280 & LF & $\$ 1.02$ & $\$ 2,325.60$ & 312316140350 \\
\hline Install direct burial cable to power lights & 2,280 & LF & $\$ 20.17$ & $\$ 45,987.60$ & 260519201600 \\
\hline Compact and backfill trench by hand & 2,280 & LF & $\$ 1.21$ & $\$ 2,758.80$ & 312316141350 \\
\hline Install panelboard, $120 / 208 \mathrm{~V}, 225 \mathrm{amp}$ & 1 & EA & $\$ 1,900.00$ & $\$ 1,900.00$ & 262416300750 \\
\hline Grounding copper wire, stranded & 8 & LF & $\$ 265.00$ & $\$ 2,120.00$ & 260526800600 \\
\hline Grounding rod, 8' long, 3/4" diameter & 1 & EA & $\$ 144.00$ & $\$ 144.00$ & 260526800050 \\
\hline Grounding connection, brazed, \#2 & 1 & EA & $\$ 78.50$ & $\$ 78.50$ & 260526803000 \\
\hline Install security lights & - & - & - & - & - \\
\hline Install perimeter lights 1,000 Watt, 40 fo & 18 & EA & $\$ 6,890.00$ & $\$ 124,020.00$ & G40201103160 \\
\hline Total & & & & & $\$ 179,334.50$ \\
\hline
\end{tabular}




\begin{tabular}{|c|c|c|c|c|c|}
\hline \multicolumn{6}{|l|}{ Bring power to site } \\
\hline Install power pole & - & - & - & - & - \\
\hline Excavate for utility pole bringing power in & 1 & CY & $\$ 102.00$ & $\$ 102.00$ & 312316160100 \\
\hline Install utility pole including cross arms & 1 & EA & $\$ 685.00$ & $\$ 685.00$ & 337116337600 \\
\hline Install site transformers & - & - & - & - & - \\
\hline Pour 6" concrete pad for $5 \mathrm{kV}$ transforme & 36 & SF & $\$ 7.53$ & $\$ 270.97$ & A10301204480 \\
\hline Install transformer $5 \mathrm{KV}$ primary, $277 / 48 \mathrm{~d}$ & 2 & EA & $\$ 13,274.00$ & $\$ 26,548.00$ & 261219100100 \\
\hline Pour 6" concrete pad for $480 \mathrm{~V}$ transform & 25 & SF & $\$ 7.53$ & $\$ 188.18$ & A10301204480 \\
\hline Install transformer $480 \mathrm{~V}$ primary, $120 / 20$ & 1 & EA & $\$ 2,525.00$ & $\$ 2,525.00$ & 262213103100 \\
\hline Total & & & & & $\$ 30,319.15$ \\
\hline & & & & & \\
\hline \multicolumn{6}{|l|}{ Build blower system } \\
\hline Install blower & - & - & - & - & - \\
\hline Build support structure & 800 & SF & $\$ 37.15$ & $\$ 29,723.20$ & B10103200152 \\
\hline Installs stairs & 2 & EA & $\$ 12,610.00$ & $\$ 25,220.00$ & C20101100660 \\
\hline Install pipes--2' & 1,260 & LB & $\$ 12.35$ & $\$ 15,561.00$ & 233113131040 \\
\hline Install pipes--3' & 524 & LB & $\$ 12.35$ & $\$ 6,471.40$ & 233113131040 \\
\hline Install blower [need type] & 42 & EA & $\$ 6,075.00$ & $\$ 255,150.00$ & 233416103600 \\
\hline Install power lines, breakers, and swit & - & - & - & - & - \\
\hline Trench for cable to blower $2 / 0$ wire & 1,700 & LF & $\$ 1.02$ & $\$ 1,734.00$ & 312316140350 \\
\hline Install direct burial cable for blower (ass & 1,700 & LF & $\$ 20.17$ & $\$ 34,289.00$ & 260519201600 \\
\hline Compact and backfill by hand trench & 1,700 & LF & $\$ 1.21$ & $\$ 2,057.00$ & 312316141350 \\
\hline Install panelboard, & 2 & EA & $\$ 4,500.00$ & $\$ 9,000.00$ & 262416301450 \\
\hline Grounding copper wire, stranded & 8 & LF & $\$ 265.00$ & $\$ 2,120.00$ & 260526800600 \\
\hline Grounding rod, 8' long, 3/4" diameter & 1 & EA & $\$ 144.00$ & $\$ 144.00$ & 260526800050 \\
\hline Grounding connection, brazed, \#2 & 1 & EA & $\$ 78.50$ & $\$ 78.50$ & 260526803000 \\
\hline Install 60 amp breaker for blower & 42 & EA & $\$ 116.00$ & $\$ 4,872.00$ & 262416200500 \\
\hline Install 60 amp safety switch at blower & 42 & EA & $\$ 665.00$ & $\$ 27,930.00$ & 262816200300 \\
\hline Total & & & & & $\$ 414,350.10$ \\
\hline \multicolumn{6}{|l|}{ Build water stand } \\
\hline Excavate additional depth for water st & - & - & - & - & - \\
\hline Excavate an additional 6 " for water stand & 52 & $\mathrm{CY}$ & $\$ 3.00$ & $\$ 155.56$ & 312316462020 \\
\hline Load 'excess' soil into dump trucks & 52 & CY & $\$ 1.24$ & $\$ 64.30$ & 312316421650 \\
\hline Haul away 'excess' soil in dump trucks & 52 & CY & $\$ 12.75$ & $\$ 661.11$ & 312323201102 \\
\hline New base material & - & - & - & - & - \\
\hline Load up base course material to make & 39 & $\mathrm{CY}$ & $\$ 1.24$ & $\$ 48.22$ & 312316421650 \\
\hline Haul base course material 10 mile trip & 39 & $\mathrm{CY}$ & $\$ 12.75$ & $\$ 495.83$ & 312323201102 \\
\hline Spread fill material to make 6" deep & 39 & CY & $\$ 2.03$ & $\$ 78.94$ & 312323170020 \\
\hline Grade fill material & 156 & SY & $\$ 0.84$ & $\$ 130.67$ & 312216100100 \\
\hline Compact fill material & 39 & CY & $\$ 1.39$ & $\$ 54.06$ & 312323240400 \\
\hline Place concrete for water stand & - & - & - & - & - \\
\hline Install welded wire fabric reinforcement & 14 & CSF & $\$ 52.05$ & $\$ 728.70$ & 32205500100 \\
\hline Pour 6" concrete slab with gravel base a & 1,400 & SF & $\$ 9.44$ & $\$ 13,213.20$ & A10301204520 \\
\hline Pour thicker edges of slab of $24 " \mathrm{"} 24 \mathrm{"} \mathrm{a}$ & 180 & LF & $\$ 43.00$ & $\$ 7,740.00$ & 33053404750 \\
\hline Install control joints & 280 & LF & $\$ 0.82$ & $\$ 229.60$ & 33529350160 \\
\hline Total & & & & & $\$ 23,600.19$ \\
\hline
\end{tabular}




\begin{tabular}{|c|c|c|c|c|c|}
\hline \multicolumn{6}{|l|}{ Install water line } \\
\hline Trench for water line & 886 & LF & $\$ 1.02$ & $\$ 903.72$ & 312316140350 \\
\hline Install pipe bvedding & 886 & LF & $\$ 3.07$ & $\$ 2,718.25$ & G10308151440 \\
\hline Install water line & 886 & LF & $\$ 32.40$ & $\$ 28,706.40$ & 221113740150 \\
\hline Compact and backfill trench by hand & 886 & LF & $\$ 1.21$ & $\$ 1,072.06$ & 312316141350 \\
\hline Total & & & & & $\$ 33,400.43$ \\
\hline \multicolumn{6}{|l|}{ Install drainage ditches } \\
\hline Cut ditch & 1,500 & If & $\$ 15.67$ & $\$ 23,497.50$ & G10308053820 \\
\hline Excavate an additional 6 " for base mate & 458 & CY & $\$ 3.00$ & $\$ 1,375.00$ & 312316462020 \\
\hline Load 'excess' soil into dump trucks & 458 & $\mathrm{CY}$ & $\$ 1.24$ & $\$ 568.33$ & 312316421650 \\
\hline Haul away 'excess' soil in dump trucks & 458 & CY & $\$ 12.75$ & $\$ 5,843.75$ & 312323201102 \\
\hline Total & & & & & $\$ 31,284.58$ \\
\hline Total cost for 'bare bone' facility & & & & & $\$ 1,354,714.70$ \\
\hline
\end{tabular}




\begin{tabular}{|c|c|c|c|c|c|}
\hline Build shared or optional facilities & & & & & \\
\hline \multicolumn{6}{|l|}{ Build administration facility } \\
\hline Excavate additional depth & - & - & - & - & - \\
\hline Excavate an additional 6 " for base mate & 33 & CY & $\$ 3.00$ & $\$ 100.00$ & 312316462020 \\
\hline Load 'excess' soil into dump trucks & 33 & CY & $\$ 1.24$ & $\$ 41.33$ & 312316421650 \\
\hline Haul away 'excess' soil in dump trucks & 33 & $\mathrm{CY}$ & $\$ 12.75$ & $\$ 425.00$ & 312323201102 \\
\hline New base material & - & - & - & - & - \\
\hline Load up base course material to make & 25 & $\mathrm{CY}$ & $\$ 1.24$ & $\$ 31.00$ & 312316421650 \\
\hline Haul base course material 10 mile trip & 25 & $\mathrm{CY}$ & $\$ 12.75$ & $\$ 318.75$ & 312323201102 \\
\hline Install foundation & - & - & - & - & - \\
\hline Install welded wire fabric reinforcement & 9 & CSF & $\$ 52.05$ & $\$ 468.45$ & 32205500100 \\
\hline Pour concrete slab & 900 & SF & $\$ 9.44$ & $\$ 8,494.20$ & A10301204520 \\
\hline Pour thicker edges of slab of 24 " $\times 24$ " a & 120 & LF & $\$ 43.00$ & $\$ 5,160.00$ & 33053404750 \\
\hline Install control joints & 180 & LF & $\$ 0.82$ & $\$ 147.60$ & 33529350160 \\
\hline Install building & - & - & - & - & - \\
\hline Install pre-engineered building & 900 & SF & $\$ 15.85$ & $\$ 14,265.00$ & 133419502100 \\
\hline Install anchor bolts in set of 4 & 6 & Sets & $\$ 61.50$ & $\$ 369.00$ & 50523051150 \\
\hline Frame up doors & 2 & EA & $\$ 530.00$ & $\$ 1,060.00$ & 133419506050 \\
\hline Install personnal doors & 0 & EA & $\$ 900.00$ & $\$ 0.00$ & 133419505750 \\
\hline Frame up windows & 0 & EA & $\$ 510.00$ & $\$ 0.00$ & 133419506200 \\
\hline Install windows $4^{\prime} \times 3^{\prime}$ & 0 & EA & & & \\
\hline Install insulation & 2,129 & SF & $\$ 0.97$ & $\$ 2,065.01$ & 133419506720 \\
\hline Install rain gutter & 60 & LF & $\$ 10.60$ & $\$ 636.00$ & 133419506550 \\
\hline Install downspout & 25 & LF & $\$ 6.65$ & $\$ 166.25$ & 77123100400 \\
\hline Finish interior & - & - & - & - & - \\
\hline Install interior walls $2 \times 4 @ 16 "$ o.c. with & 1,760 & SF & $\$ 5.29$ & $\$ 9,312.16$ & C10101241250 \\
\hline Paint interior walls, 1 coat of primer and & 1,760 & SF & $\$ 0.96$ & $\$ 1,693.12$ & C30102300140 \\
\hline InstallI 5/8" Accoustical tile $2^{\prime} \times 4^{\prime}$ ceiling & 900 & SF & $\$ 4.26$ & $\$ 3,837.60$ & C30302105800 \\
\hline Additional amount for carrior channels s & 900 & SF & $\$ 1.72$ & $\$ 1,544.40$ & C30302403340 \\
\hline Install floor covering & 900 & SF & & & \\
\hline Install HVAC & - & - & - & - & - \\
\hline Install mechanical system HVAC & 1 & & $\$ 15,000.00$ & $\$ 15,000.00$ & 238143101120 \\
\hline Install ductwork & 1 & & $\$ 15,000.00$ & $\$ 15,000.00$ & \\
\hline Install electrical power to building & - & - & - & - & - \\
\hline Trench for cable to building & 36 & LF & $\$ 1.02$ & $\$ 36.72$ & 312316140350 \\
\hline Install direct burial cable for building (as & 36 & LF & $\$ 20.17$ & $\$ 726.12$ & 260519201600 \\
\hline Compact and backfill by hand trench & 36 & LF & $\$ 1.21$ & $\$ 43.56$ & 312316141350 \\
\hline Install service weatherhead & 1 & EA & $\$ 4,745.00$ & $\$ 4,745.00$ & D50101200280 \\
\hline Install panelboard, 120/208V, $225 \mathrm{amp}$ & 1 & EA & $\$ 1,900.00$ & $\$ 1,900.00$ & 262416300750 \\
\hline Grounding copper wire, stranded & 8 & LF & $\$ 265.00$ & $\$ 2,120.00$ & 260526800600 \\
\hline Grounding rod, 8' long, 3/4" diameter & 1 & EA & $\$ 144.00$ & $\$ 144.00$ & 260526800050 \\
\hline Grounding connection, brazed, \#2 & 1 & EA & $\$ 78.50$ & $\$ 78.50$ & 260526803000 \\
\hline Install electrical items & - & - & - & - & - \\
\hline Install wiring distribution system & 3 & CLF & $\$ 293.00$ & $\$ 820.40$ & 260519550250 \\
\hline Install outside lights & 900 & SF & $\$ 2.59$ & $\$ 2,328.30$ & D50202220280 \\
\hline Install receptacles & 900 & SF & $\$ 2.24$ & $\$ 2,012.40$ & D50201100200 \\
\hline Install light switches & 4 & EA & $\$ 318.50$ & $\$ 1,274.00$ & D50201250720 \\
\hline Install 2 tube $34 \mathrm{~W}$ lights interior lights & 16 & EA & $\$ 190.00$ & $\$ 3,040.00$ & 265113500940 \\
\hline Administration Building Total Cost & & & & & $\$ 99,403.87$ \\
\hline
\end{tabular}




\begin{tabular}{|c|c|c|c|c|c|}
\hline \multicolumn{6}{|l|}{ Build open bin storage } \\
\hline Excavate additional depth & - & - & - & - & - \\
\hline Excavate an additional $6 "$ for base mate & 178 & $\mathrm{CY}$ & $\$ 3.00$ & $\$ 533.33$ & 312316462020 \\
\hline Load 'excess' soil into dump trucks & 178 & CY & $\$ 1.24$ & $\$ 220.44$ & 312316421650 \\
\hline Haul away 'excess' soil in dump trucks & 178 & $\mathrm{CY}$ & $\$ 12.75$ & $\$ 2,266.67$ & 312323201102 \\
\hline New base material & - & - & - & - & - \\
\hline Load up base course material to make & 178 & $\mathrm{CY}$ & $\$ 1.24$ & $\$ 220.44$ & 312316421650 \\
\hline Haul base course material 10 mile trip & 178 & $\mathrm{CY}$ & $\$ 12.75$ & $\$ 2,266.67$ & 312323201102 \\
\hline Install foundation & - & - & - & - & - \\
\hline Install welded wire fabric reinforcement & 0 & CSF & $\$ 52.05$ & $\$ 0.00$ & 32205500100 \\
\hline Pour concrete slab & 1,600 & SF & $\$ 9.44$ & $\$ 15,100.80$ & A10301204520 \\
\hline Pour thicker edges of slab of $24 " \times 24 " a$ & 0 & LF & $\# \mathrm{~N} / \mathrm{A}$ & & 33053404750 \\
\hline Install control joints & & LF & $\$ 0.82$ & $\$ 0.00$ & 33529350160 \\
\hline Construct walls & - & - & - & - & - \\
\hline Install walls & 720 & LF & $\$ 26.07$ & $\$ 18,766.80$ & B20101014000 \\
\hline Open Bin Total Cost & & & & & $\$ 39,375.16$ \\
\hline \multicolumn{6}{|l|}{ Install gravel road } \\
\hline Excavate additional depth for road & - & - & - & - & - \\
\hline Excavate an additional 4" aspahlt road & 1,199 & $\mathrm{CY}$ & $\$ 3.00$ & $\$ 3,596.30$ & 312316462020 \\
\hline Load 'excess' soil into dump trucks & 1,199 & CY & $\$ 1.24$ & $\$ 1,486.47$ & 312316421650 \\
\hline Haul away 'excess' soil in dump trucks & 1,199 & $\mathrm{CY}$ & $\$ 12.75$ & $\$ 15,284.26$ & 312323201102 \\
\hline Base Material & - & - & - & - & - \\
\hline Load base course material (to make 6" & 1,079 & $\mathrm{CY}$ & $\$ 1.24$ & $\$ 1,337.82$ & 312316421650 \\
\hline Compact 6" base course material & 1,079 & CY & $\$ 1.39$ & $\$ 1,499.66$ & 312323240400 \\
\hline Road Total Cost & & & & & $\$ 23,204.50$ \\
\hline SUBTOTAL & & & & $\$ 1,516,698$ & $\$ 1,516,698$ \\
\hline City cost index & $100.0 \%$ & & & & \\
\hline TOTAL & & & & $\$ 1,516,698$ & \\
\hline TOTAL with contingency of: & $20 \%$ & & & $\$ 1,820,038$ & \\
\hline TOTAL with contingency of: & $50 \%$ & & & $\$ 2,275,047$ & \\
\hline ROUNDED TO & & & & $\$ 1,820,000$ & \\
\hline ROUNDED TO & & & & $\$ 2,275,000$ & \\
\hline
\end{tabular}




\section{Appendix F: Notes from Artemis Advantage, LLC. Regarding Off-Site Options}




\section{Vernon/Beauregard Parish Regional Composting Facility Outlook}

\section{Provided by Artemis Advantage LLC.}

To develop a regional composting facility, at least 4 items will need to be addressed: financial backing, feedstock accessibility, land availability, and an agreeable political environment. To determine the availability of these items, the communities surrounding Ft. Polk were contacted to assess their interest in a regional composting facility.

Artemis Advantage, LCC, a local environmental consulting firm, held discussions with key personnel from the cities of Leesville and DeRidder, Beauregard Parish, the local paper mill, potential investors, and a volunteer citizen's group dedicated to reducing waste in the area. All entities are supportive of the concept and have indicated they would be interested in being part of the planning and development of a regional composting facility. Efforts are currently underway by Artemis Advantage to bring community members together for a tour of existing, successful composting facilities in the state. The aim will be to initiate discussions to define a concrete plan toward the development and operation of a regional composting facility.

DeRidder Mayor, Ron Roberts, believes a regional composting facility would be welcomed in the DeRidder area at the industrial site located near the DeRidder airport. Mayor Roberts is very excited about the possibilities to help the community reduce waste and possibly bring a new industry into the area. He says, "This is a concept that has been discussed for a while in the community and we believe that the time is right to make this a reality in DeRidder." 
Leesville Mayor, Robert Rose, is supportive of a Regional Composting Facility and believes the implementation of such is long overdue. He is very interested in pursuing future discussions regarding a possible implementation of this type of facility in the area. He has mentioned that the existing C\&D Vernon Parish landfill is targeted for closure, which will necessitate the need for alternative solutions for processing of these wastes, which includes green waste.

Bobby Hennigan, administrator for the Beauregard Parish Policy Jury, is interested in investigating more about the potential for housing a composting facility in the parish. Discussion of the topic is scheduled with the Economic Development and Landfill and Solid Waste Police Jury Committees during April 2013.

The Boise Environmental Department at the DeRidder Paper Mill has expressed an interest in the concept of a regional composting facility. The local Environmental Manager, Blaine Butaud, has indicated paper sludge produced as a byproduct of their processes, at the current rate of approximately 45 dry tons/day, could be used as a potential feed stock for a composting facility. Mr. Butaud has indicated a willingness to work with area municipalities, entities and businesses to explore the possibility of turning this concept into a reality.

Mr. Butaud stated that the sludge material is composed of short cellulose fibers and has been analyzed using USEPA Appendix 9 protocols and all contaminants are at de minimis levels. The material has been approved for land application under a Beneficial Management Plan with Louisiana Department of Agriculture and Forestry and Louisiana Department of Environmental Quality.

Two separate area businessmen with experience in developing and managing composting facilities were also approached by Artemis. Both 
indicated they would be interested in "sitting at the table" to discuss the possibilities involved in setting up a composting facility in the Ft. Polk/Vernon/Beauregard area. Each is interested in investing in this initiative and has asked to be included in conceptual/feasibility discussions. It is noteworthy that these potential investors have experience in the field and expressed excitement in the possibility of expanding their composting capabilities into other parts of the state.

In addition to the above, Artemis Advantage has also worked closely with a local volunteer citizens group, the NZW Citizen's Brigade, dedicated to reducing waste in the region. This group is very supportive of a composting facility and would be anxious to help raise awareness of the benefits of composting. The group sees this as a direct help to one of their primary goals of encouraging and developing community gardens.

The political and financial climate in the Beauregard/Vernon area shows that a regional composting facility is desired and is a real possibility. With appropriate vision and leadership this concept could become a reality in the near future.

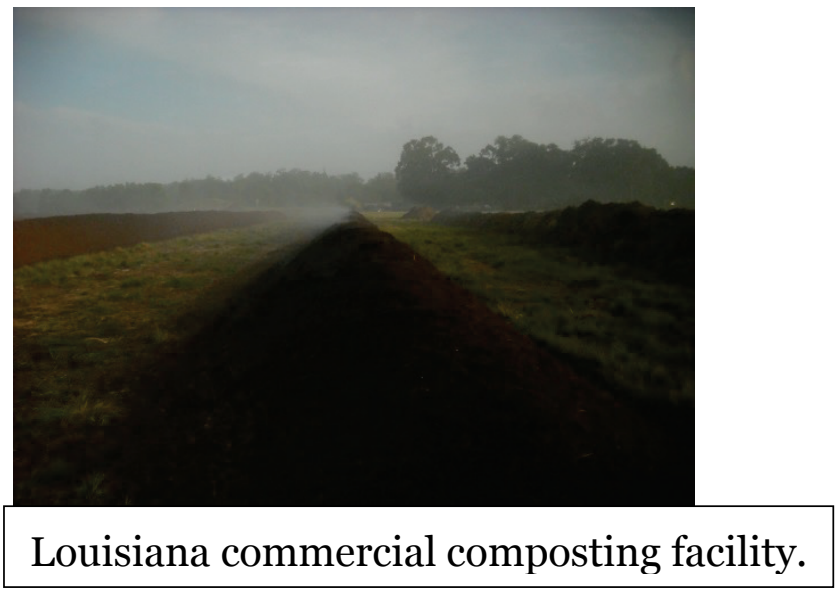




\section{Appendix G: Breakeven calculations for five scenarios}

\begin{tabular}{|c|c|c|c|c|c|c|c|c|c|}
\hline \multicolumn{2}{|c|}{ Scenario 1 . Costs based on study results } & & & & \multicolumn{2}{|c|}{ Scenario 2 . reduce initial setup costs } & & & \\
\hline \multirow{2}{*}{$\begin{array}{l}\text { Costs for Construction and Setup } \\
\text { Constuction of Site }\end{array}$} & & & & & \multicolumn{2}{|c|}{ Costs for Construction and Setup } & & & \\
\hline & & & & & & & & & \\
\hline & $\$ 2,250,000.00$ & & & & & $\$ 1,800,000.00$ & & & \\
\hline \multirow[t]{2}{*}{ Equipment } & $\$ 250,000.00$ & & & & Equipment & $\$ \quad 150,000.00$ & & & \\
\hline & & & & & & & & & \\
\hline \multirow[t]{2}{*}{ Total investiment } & $\$ 2,500,000.00$ & & & & Total investiment & $\$ 1,950,000.00$ & & & \\
\hline & & & & & & & & & \\
\hline Annual Operational Costs & & & & & Annual Operational costs & & & & \\
\hline \multirow[t]{2}{*}{ Labor } & FTES & Annual Wage & Total & & Labor & FTES & Annual Wage & Total & \\
\hline & 2 & $40,000.00$ & $\$ 80,000.00$ & & & 2 & $2 \$ 40,000.00$ & $\$ 80,000.00$ & \\
\hline \multirow{2}{*}{ Operational Costs } & $\$ 40,000,00$ & & & & Operational costs & $40,000,00$ & & & \\
\hline & $40,000.00$ & & & & 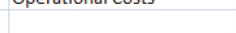 & $40,000.00$ & & & \\
\hline \multirow[t]{2}{*}{ Total Annual } & $\$ 120,000.00$ & & & & Total Annual & $\$ \quad 120,000.00$ & & & \\
\hline & & & & & & & & & \\
\hline \multirow{3}{*}{$\begin{array}{l}\text { Annual Savings } \\
\text { Disposal Costs }\end{array}$} & & & & & Annual Savings & & & & \\
\hline & tons/wk & Fee/ton & $\mathrm{wk} / \mathrm{yr}$ & Total & Disposal Costs & tons/wk & Fee/ton & $\mathrm{wk} / \mathrm{yr}$ & Total \\
\hline & 46 & 80.00 & 52 & $2 \$ 191,360.00$ & & 46 & 80.00 & 52 & $2 \$ 191,360.00$ \\
\hline & & & & & & & & & \\
\hline & & & & & & & & & \\
\hline \multirow[t]{2}{*}{ Fertilizer } & tons/wk & Saved cost/ton & $\mathrm{wk} / \mathrm{yr}$ & Total & Fertilizer & tons/wk & Saved cost/ton & $\mathrm{wk} / \mathrm{yr}$ & Total \\
\hline & 46 & 25.00 & 52 & $2 \$ 59,800.00$ & & 46 & 25.00 & 52 & $2 \$ 59,800.00$ \\
\hline Total Savings & $\$ 251,160.00$ & & & & Total Savings & $\$ 251,160.00$ & & & \\
\hline & & & & & & & & & \\
\hline Total Benefit Annually & $\$ 131,160.00$ & & & & Total Benefit Annually & $\$ 131,160.00$ & & & \\
\hline & & & & & & & & & \\
\hline Years to pay off initial investment & 19.1 & 1 years & & & Years to pay off initial invest & 14.9 & 9 years & & \\
\hline Scenario 3. Reduce labor costs & & & & & Scenario 4. Combined Scena & rio 2 and 3 & & & \\
\hline & & & & & & & & & \\
\hline Costs for Construction and Setup & & & & & Costs for Construction and S & etup & & & \\
\hline Constuction of Site & & & & & Constuction of Site & & & & \\
\hline & $\$ 2,250,000.00$ & & & & & $\$ 1,800,000.00$ & & & \\
\hline Equipment & $\$ 250,000.00$ & & & & Equipment & $\$ \quad 150,000.00$ & & & \\
\hline & & & & & & & & & \\
\hline Total investiment & $\$ 2,500,000.00$ & & & & Total investiment & $\$ 1,950,000.00$ & & & \\
\hline & & & & & & & & & \\
\hline Annual Operational Costs & & & & & Annual Operational Costs & & & & \\
\hline Labor & FTES & Annual Wage & Total & & Labor & FTES & Annual Wage & Total & \\
\hline & 1 & $40,000.00$ & $\$ 40,000.00$ & & & 1 & $1 \$ \quad 40,000.00$ & $\$ 40,000.00$ & \\
\hline Operational costs & $\$ \quad 40,000.00$ & & & & Operational Costs & $40,000.00$ & & & \\
\hline & & & & & & & & & \\
\hline Total Annual & $\$ 80,000.00$ & & & & Total Annual & $80,000.00$ & & & \\
\hline & & & & & & & & & \\
\hline Annual Savings & & & & & Annual Savings & & & & \\
\hline Disposal Costs & tons/wk & Fee/ton & $\mathrm{wk} / \mathrm{yr}$ & Total & Disposal Costs & tons/wk & Fee/ton & $w k / y r$ & Total \\
\hline & 46 & 80.00 & 52 & $2 \$ 191,360.00$ & & 46 & 80.00 & 52 & $2 \$ 191,360.00$ \\
\hline & & & & & & & & & \\
\hline Fertilizer & tons/wk & Saved cost/ton & $\mathrm{wk} / \mathrm{yr}$ & Total & Fertilizer & tons/wk & Saved cost/ton & $w k / y r$ & Total \\
\hline & 46 & 25.00 & 52 & $2 \$ 59,800.00$ & & 46 & 25.00 & 52 & $2 \$ 59,800.00$ \\
\hline Total Savings & $\$ 251,160.00$ & & & & Total Savings & $\$ \quad 251,160.00$ & & & \\
\hline & & & & & & & & & \\
\hline Total Benefit Annually & $\$ 171,160.00$ & & & & Total Benefit Annually & $\$ \quad 171,160.00$ & & & \\
\hline & & & & & & & & & \\
\hline Years to pay off initial investment & 14.6 & 6 years & & & Years to pay off initial invest & 11.4 & 4 years & & \\
\hline
\end{tabular}




\begin{tabular}{|c|c|c|c|c|}
\hline \multicolumn{5}{|l|}{ Scenario 5 . Increase diversion by $50 \%$} \\
\hline \multicolumn{5}{|l|}{ Costs for Construction and Setup } \\
\hline \multicolumn{5}{|l|}{ Constuction of Site } \\
\hline & $\$ 2,250,000.00$ & & & \\
\hline Equipment & $\$ 250,000.00$ & & & \\
\hline Total investiment & $\$ 2,500,000.00$ & & & \\
\hline \multicolumn{5}{|l|}{ Annual Operational Costs } \\
\hline \multirow[t]{2}{*}{ Labor } & FTEs & Annual Wage & Total & \\
\hline & 2 & $\$ \quad 40,000.00$ & $\$ 80,000.00$ & \\
\hline Operational Costs & $\$ \quad 40,000.00$ & & & \\
\hline Total Annual & $\$ 120,000.00$ & & & \\
\hline \multicolumn{5}{|l|}{ Annual Savings } \\
\hline \multirow[t]{2}{*}{ Disposal Costs } & tons/wk & Fee/ton & wk/yr & Total \\
\hline & 69 & 80.00 & 52 & $\$ 287,040.00$ \\
\hline \multirow[t]{2}{*}{ Fertilizer } & tons/wk & Saved cost/ton & wk/yr & Total \\
\hline & 69 & 25.00 & 52 & $\$ \quad 89,700.00$ \\
\hline Total Savings & $\$ 376,740.00$ & & & \\
\hline Total Benefit Annually & $\$ 256,740.00$ & & & \\
\hline Years to pay off initial investment & 9.7 & years & & \\
\hline
\end{tabular}




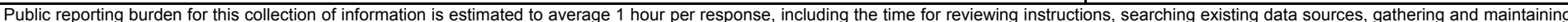

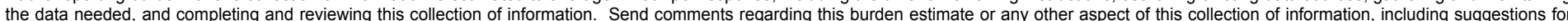

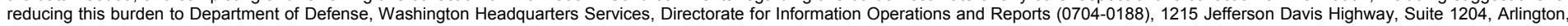

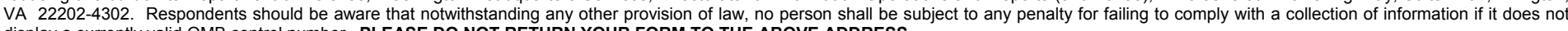
display a currently valid OMB control number. PLEASE DO NOT RETURN YOUR FORM TO THE ABOVE ADDRESS.
1. REPORT DATE (DD-MM-YYYY) 2. REPORT TYPE Final report
3. DATES COVERED (From - To)

April 2014

\section{TITLE AND SUBTITLE}

Composting Assessment for Organic Solid Waste at Fort Polk, Louisiana

5a. CONTRACT NUMBER

PM-0104046

5b. GRANT NUMBER

5c. PROGRAM ELEMENT NUMBER

\section{AUTHOR(S)}

Victor F. Medina, Michelle Wynter, Stephen Cosper, Giselle Rodriguez, Dick Gebhart, Sam Hunter, Patricia Kemme

5d. PROJECT NUMBER

\section{5e. TASK NUMBER}

\section{5f. WORK UNIT NUMBER}

\section{PERFORMING ORGANIZATION NAME(S) AND ADDRESS(ES)}

U.S. Army Engineer Research and Development Center

Environmental Laboratory

3909 Halls Ferry Road, Vicksburg, MS 39180-6199;

Construction Engineering Research Laboratory

2909 Newmark Dr.

Champaign, IL 61826-9005

9. SPONSORING / MONITORING AGENCY NAME(S) AND ADDRESS(ES)

Department of Public Works at Fort Polk, Louisiana

\section{PERFORMING ORGANIZATION REPORT} NUMBER

ERDC TR-14-2

10. SPONSOR/MONITOR'S ACRONYM(S)

11. SPONSOR/MONITOR'S REPORT NUMBER(S)

\section{DISTRIBUTION / AVAILABILITY STATEMENT}

Approved for public release; distribution unlimited.

\section{SUPPLEMENTARY NOTES}

\section{ABSTRACT}

A study was conducted to evaluate composting as a means of increasing waste diversion at Ft. Polk, LA. Wastes were evaluated from a range of activities, and the authors found that a number of materials currently landfilled are suitable for composting, including: vegetation, food wastes, pulverized paper (which is not suitable for recycling), consumer contaminated paper (not suitable for recycling), damaged wood pallets, and sludge from the wastewater treatment plants. Waste records from Ft. Polk suggest a composting operation producing at least 2200 tons per year (from a food waste/vegetation strategy) is feasible. This would represent considerable solid waste diversion, consistent with meeting Net Zero Waste Goals. Between the Integrated Training Area Management (ITAM), the Directorate for Family, Morale, Welfare, and Recreation (DFMWR) (golf course, athletic and drill fields) and smaller users, there are enough users to consume all the compost that could be generated from an on-site operation. A suitable area for on-site composting is available. There are also other alternatives to on-site composting, including current management, other means of waste diversion (including direct soil application of certain waste materials and anaerobic digestion of food wastes), and developing partnerships with composting facilities offsite. Although this project is focused on Ft. Polk, the assessment could be - in a broad sense - applicable to other Army installations. In addition, the issues found at the Joint Training and Readiness Center (JTRC) might have applicability to contingency environments and deployed operations.
15. SUBJECT TERMS
Net Zero Waste
Waste Diversion
Composting
Organic Solid Waste
Ft. Polk
Waste

16. SECURITY CLASSIFICATION OF:

a. REPORT

UNCLASSIFIED

b. ABSTRACT
UNCLASSIFIED

c. THIS PAGE

UNCLASSIFIED
17. LIMITATION OF ABSTRACT

\section{NUMBER} OF PAGES

112 19a. NAME OF RESPONSIBLE PERSON

Deborah Felt 19b. TELEPHONE NUMBER (include area code) 601-634-3576 